\title{
EFFECT OF LEMMA COLOUR ON GRAIN QUALITY \\ IN OATS, AVENA SATIVA L.
}

\author{
A Thesis \\ Submitted to the Faculty \\ of \\ Graduate Studies \\ The University of Manitoba \\ by \\ Ariane Plourde \\ In Partial Fulfillment of the \\ Requirements for the Degree \\ of \\ Master of Science \\ Department of Plant Science \\ November 1984
}




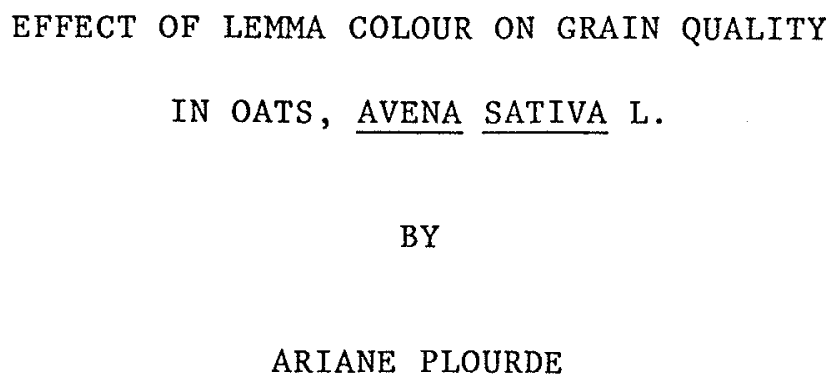

Permission has been granted to the LIBRARY OF THE UNIVERSITY OF MANITOBA to lend or sell copies of this thesis. to the NATIONAL LIBRARY OF CANADA to microfilm this thesis and to lend or sell copies of the film, and UNIVERSITY MICROFILMS to publish an abstract of this thesis.

The author reserves other publication rights, and neither the thesis nor extensive extracts from it may be printed or otherwise reproduced without the author's written permission. 


\section{ACKNOWLEDGMENTS}

I wish to express sincere appreciation to $\mathrm{Dr}$. R.I.H. McKenzie for his guidance and continuous support throughout this study. I also would like to thank $\mathrm{Dr}$. P.D. Brown for his support and suggestions in the preparation of this manuscript.

Appreciation is also extended to $\mathrm{Mr}$. R. Bristow and R. Stecy for their technical assistance; to the staff at the Winnipeg Research Station for the use of the facilities and warm cooperation; to the graduate students especially Greg Penner, Brad Gabor, Suzanne Guénette, Pierre-Philippe Claude and Tom Warkentin for their help, friendship and moral support.

Financial support from The Quaker Oats Company of Canada is gratefully acknowledged.

Finally, I wish to thank my boyfriend Daniel and my family for their encouragement and moral support during my stay in Manitoba. 


\section{FOREWORD}

This thesis is written in the paper style, specified in the 1976 Plant Science Thesis Preparation Guide. It contains two manuscripts. The first, entitled " Effect of lemma colour on grain quality in oats, Avena sativa L." will be submitted to the Canadian Journal of Plant Science. The second, entitled " The inheritance of lemma colour in oats, Avena sativa L." will be submitted to the Canadian Journal of Genetics and Cytology as a note. 
TABLE OF CONTENTS

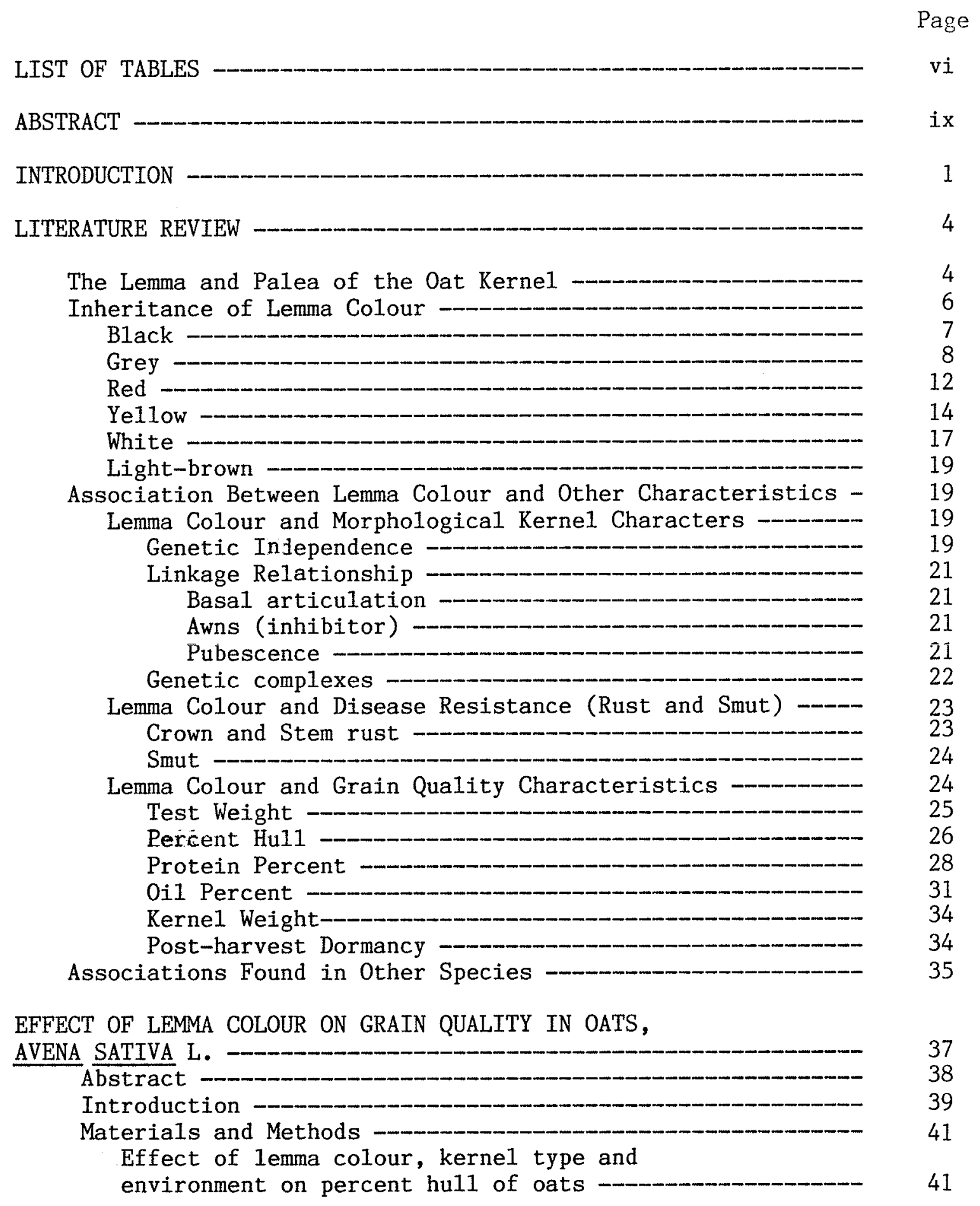


Effect of lemma colour on grain quality in oats -_-_ 41

Results - 45

Effect of lemma colour, kernel type and

environment on percent hull of oats - 45

Effect of lemma colour on agronomic characters

in oats (1984) - 46

Effect of lemma colour on grain quality in oats _-_-_-_ 47

White versus Red -__ $\quad 47$

Yellow versus Red -__ 48

Yellow versus White -_____-_ 49

Black versus Non-black - 50

Discussion - 50

Effect of lemma colour, kernel type and

environment on percent hull of oats $\quad 50$

Effect of lemma colour on grain quality in oats -_- 51

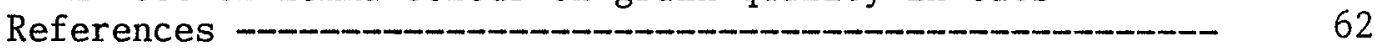

THE INHERITANCE OF LEMMA COLOUR IN OATS, AVENA SATIVA L.----- 63

Abstract -____________ 64

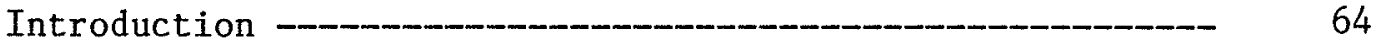

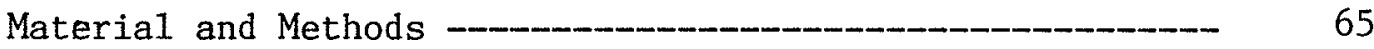

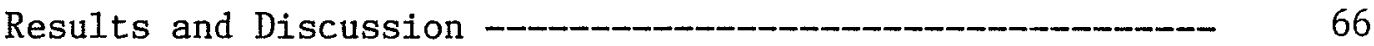

References -___- 72

GENERAL DISCUSSION - 73

LIST OF REFERENCES - 81

APPENDICES - 86 


\section{Literature Review}

1. Segregation ratios for each colour combination involving black lemma colour --

2. Segregation ratios obtained for each colour combination involving grey lemma colour

3. Segregation ratios for each colour combination involving red lemma colour

4. Segregation ratios obtained for the three colour combinaisons yellow $X$ yellow, yellow $X$ white and white $X$ white

5. Oat genes for lemma colour (Simons et al (1978)

6. Proximate fat content of cereal grains (dry matter basis) after Kent (1975)

Effect of Lemma Colour on Grain Quality in Oats, Avena sativa L.

1. Parents used in the study of the effect of lemma colour on grain quality in oats

2. Mean hull percentage of primary, secondary and combined data of four oat lines differing in hull colour and grown at five locations in 1982 and 1983

3. Analyses of variance of hull percentage of four oat lines differing in hull colour and grown at five 1ocations in 1982 and 1983

4. Mean values of heading date, height and yield for the four lemma colour comparison experiments grown at Glenlea, Manitoba in 1984

5. Effect of near-isogenic lines differing in lemma colour on grain quality characteristics of oats in 1983 and 1984

6. Effect of white versus red lemma colour on percent hull 
of primary kernels of near-isogenic oat lines derived from five different crosses in 1983 and 1984

7. Effect of white versus red lemma colour on test weight of near-isogenic oat lines derived from five different crosses

The Inheritance of Lemma Colour in Oats, Avena sativa L.

1. Segregation of $F_{2}$ plant population from crosses between Avena sativa varieties of different lemma colours _-_._ 70

2. Segregation for lemma colour in the $F_{3}$ families of Fidler X Caravelle and OT 224 X Caravêlle -_______-_._-

Appendix

1. Mean values for the agronomic and grain quality characteristics of the white versus red near-isogenic pairs of 1ines grown at Glenlea, Manitoba in 1983 and 1984 --

2. Mean values for the agronomic and grain quality characteristics of the yellow versus red near-isogenic pairs of lines grown at Glenlea, Manitoba in 1983 and 1984 --

3. Mean values for the agronomic and grain quality characteristics of the yellow versus white near-isogenic pairs of lines grown at Glenlea, Manitoba in 1983 and and 1984

4. Mean values for the agronomic and grain quality characteristics of the black versus non-black near-isogenic pairs of lines grown at Glenlea, Manitoba in 1983 and 1984

5. Number of days to reach maximum germination, percent germination and germination index of the white versus red near-isogenic pairs of lines grown in greenhouse in 1984

6. Number of days to reach maximum germination, percent germination and germination index of the yellow versus red near-isogenic pairs of lines grown in greenhouse in 1984

7. Number of days to reach maximum germination, percent germination and germination index of the yellow versus white near-isogenic pairs of lines grown in greenhouse in 1984 
8. Number of days to reach maximum germination, percent germination and germination index of the black versus non-black near-isogenic pairs of lines grown in the greenhouse in 1984

9. Whole grain protein percent and groat protein percent of the white versus red near-isogenic pairs of lines grown at Glenlea, Manitoba in 1983 -

10. Whole grain protein percent and groat protein percent of the yellow versus red near-isogenic pairs of lines grown at Glenlea, Manitoba in 1983

11. Whole grain protein percent and groat protein percent of the yellow versus white near-isogenic pairs of lines grown at Glenlea, Manitoba in 1983

12. Whole grain protein percent and groat protein percent of the black versus non-black near-isogenic pairs of lines grown at Glenlea, Manitoba in 1983

13. Analyses of variance of percent hull and percent oil of the near-isogenic lines differing in lemma colour and grown at Glenlea, Manitoba in 1983

14. Analyses of variance of the agronomic characters and grain quality characteristics of the near-isogenic lines differing in lemma colour and grown at Glenlea, Manitoba in 1984 
Plourde, Ariane. M.Sc., The University of Manitoba, November; 1984. Effect of lemma colour on grain quality in oats, Avena sativa L. Major Professor: Dr. R.I.H McKenzie.

The effect of lemma colour on grain quality in oats was studied through the use of $F_{3}$ derived near-isogenic $F_{6}$ lines of contrasting lemma colour. Of the 71 pairs selected, 36 were developed to compare white and red-seeded oats, 15 to compare yellow and red, 10 to compare yellow and white and 10 to study black versus non-black. The contrasting pairs were studied for six grain quality characteristics, viz. percent hul1, percent protein, percent oil, test weight, 1000 kernel weight and post-harvest dormancy and the three agronomic characters heading date, height and yield.

Red lemma colour was associated with a lower hull percent and a lower test weight in the white versus red and yellow versus red lemma colour comparisons. In 1984, the average difference of $1.17 \%$ hul1 between the white and red near-isogenic lines represented $4.4 \%$ improvement over the mean percent hull of the white-seeded lines. The red-seeded lines were significantly lower in percent hull in 30 out of the 36 pairs. Genetic possibilities to account for this result are discussed and include pleiotropism or a close linkage between the gene for red colour and a gene for low percent hull. A significant difference of 0.73 and 0.74 $\mathrm{kg} / \mathrm{hl}$ in test weight favouring the non-red-seeded lines was obtained in the white versus red and yellow versus red experiments respectively. The 
results suggest that the association of lemma colour and percent hull was stronger than the association of lemma colour and test weight. It would be easier to select red-seeded oat lines with a low percent hull and high test weight than white-seeded lines having a low percent hull and high test weight. Red lemma colour could serve as an index to select high quality oats.

Although showing no differences in 1983, white oats were of higher quality in 1984 with a significantly lower percent hull $(-1.70 \%$ hull difference) and a significantly higher test weight $(+2.29 \mathrm{~kg} / \mathrm{hl}$ difference) than the yellow-seeded lines. Black lemma colour seems to be associated with lower overall quality $(2.12 \%$ hull higher and $2.29 \mathrm{~kg} / \mathrm{hl}$ lower) in comparison to the other colour classes.

Red lemma colour could serve as an index to select high quality oats. No association were found between lemma colours and the agronomic characters studied so that it should be possible to select for yield, short straw and maturity within any hull colour class.

The inheritance of lemma colour was studied in crosses involving seven cultivars or lines of Avena sativa L.. Red lemma colour was controlled by one dominant gene in OT 224 and OT 218. White lemma colour of the cultivars Fidler and Rodney 0 was found to be conditioned by a dominant gene. Yellow lemma colour of the cultivars Lamar and Ogle appeared to be the expression of the homozygous recessive condition of the genes at the loci controlling red and white lemma colours. The black-seeded cultivar Caravelle was found to carry a dominant gene for black epistatic to the other colour classes and a dominant gene for white. The presence of a gene for grey lemma colour in the genotype of 
Caravelle was expressed in one environment but not at all in a second.

The character lemma colour was sometimes influenced by envirónmental conditions indicating that lemma colour which is conferred by simply inherited qualitative genes might be harder to work with than expected. Nevertheless gross differentiation between the five lemma colour classes is possible so the breeder should be able to use lemma colour as an index to select for good quality oats. 


\section{INTRODUCTION}

Oats occupy a significant place among the eight most important cereals in the world. In 1982, in terms of total production, oats (primarily Avena sativa L.) rank sixth among the cereals after wheat, corn, rice, barley and sorghum. These statistics include the cultivated species Avena sativa L., A.byzantina C.Koch, A.strigosa Schreb and A.abyssinica Hochst. The major oat producing countries are Russia, United States, Canada, West Germany, Poland, People's Republic of China, France and Sweden $(F A O, 1983)$. In Canada, oats have a relatively greater importance because no rice and only a restricted quantity of corn is grown. In 1983 this cereal (A.sativa L.) was grown on 1.4 million hectares for a total production of approximately 2.7 million metric tonnes (Statistics Canada, 1984).

In an oat breeding program the breeder's objective is to select high yielding lines with resistance to prevalent diseases and with quality characteristics meeting the market's requirements. Oats are used for two purposes, animal feed and human food, the former being by far the main use of the oat grain. The breeding objectives vary slightly depending upon the final use but the primary desirable attributes which are yield and disease resistance always remain important. However during the past 20 years percent protein and percent oil have become quality characteristics of concern. Emphasis is now placed on the improvement of oats for these two characteristics in order to increase its value on the 
market.

Selection for either protein content, oil content or lower hull percentage is expensive and time consuming due to the necessity of obtaining determinations in the laboratory for each line in the program. It would be useful if lines with the desirable quality characteristics could be selected by some easily identifiable character.

Lemma colour, an obvious character of the oat kernel, would be a very convenient index for selection of other less-visible characters. Five lemma colour classes have been recognized in oats: black (including dark brown), grey, red, yellow and white (Stanton,1961). Lemma colour has been studied extensively genetical1y (Jensen,1961) but very little information is available regarding the influence of lemma colour on grain quality traits. There are some indications that associations exist between the morphological characters lemma colour and shattering and two kernel characteristics, percent hull and percent protein in A.sativa $X$ A. sterilis progeny populations (Campbel1 and Frey,1972; LeRoy et a1,1974; Lyrene and Shands, 1975). Luby and Stuthman(1983) reported that dark lemma colour and shattering were associated with low hull percentage, low groat protein percent and low groat oil percent in A.sativa X A.fatua progeny populations. However, no investigation on such relationship has been done through the use of near-isogenic lines.

Close associations have been reported between seed colour and other characteristics in other crop species. In wheat (Triticum aestivum L.) red seed colour is used as an index to select for post-harvest dormancy (Gordon,1979). In turnip rape (Brassica campestris L.) yellow seed colour 
is linked with high protein and oil content and low crude fibre in the rape meal (Jonsson,1977). In durum wheat (Triticum turgidum L.) preliminary results suggest a strong association between white glume colour, gliadin proteins and possibly gluten strength (Leisle et a1, 1981). In flax, yellow-seeded lines are higher in 1000 kernel weight, oil content, iodine number, and amount of damaged seed but lower in test weight and yield of seed than brown-seeded lines (Culbertson and Kommedah1,1956).

The present study was undertaken to investigate the effect of lemma colour on grain quality characteristics in oats through the use of near-isogenic lines. The grain quality characteristics studied were test weight, 1000 kernel weight, percent hul1, percent protein, percent oil and post-harvest dormancy. The influence of lemma colour on some agronomic characters including yield and the inheritance of lemma colour were also investigated. 
LITERATURE REVIEW

The Lemma and Palea of the Oat Kernel

Oat spikelets consist of two glumes on a rachilla which bears several florets, generally two in cultivated oats. The floret consists of two flowering glumes called the lemma and the palea, two lodicules, three stamens and one pistil. At maturity, the oat caryopsis is tightly enclosed in the lemma and palea. The flowering glumes, although not fused to the kernel as in the case of barley, do nevertheless adhere to it and do not normally come away during threshing (Kent,1975). The common term used to designate the lemma and palea is hull.

Hulless oats exist in which the caryopsis is loose within the thin, membranous enclosed lemma and palea therefore being similar to wheat and naked barley. In threshing the kernel is freed from the hull. Hulless oats usually have multiflorous spikelets.

Histologically the lemma and palea are the leaf-like parts of the floret. Lemmas are composed of mechanical tissue. A thick layer of sclerenchyma extends inward from the outer epidermis and constitutes almost all of the tissue. Next to the inner epidermis is a narrow layer of parenchyma containing chlorophy11 (Bonnett,1961). Pigments conferring colour to this flower part are probably contained in this narrow layer of cells, replacing gradually the chlorophyll as the latter disappears during the ripening period. The palea is shaped like the prophyll which, 
in monocotyledons, is the first leaf at the base of the axillary shoot. Thinner than the lemma, the palea has less chlorophyll contained in the cells of the bands of parenchyma located on either side of the two vascular bundles. The major function of these two flowering glumes is to protect the caryopsis.

Seed colour can be the effect of the superimposition of different tissues containing similar or different pigments. For instance, in wheat, the grain colour is given by both the pigments present in the pericarp (fruit coat) and those present in the testa (seed coat). The particular shade of colour (between white and red) exhibited by the grain is dependent upon the amount of pigment in the testa, the thickness, tint and transparency of the superimposed pericarp and the mealy and flinty character of the endosperm (Percival,1921).

In barley, two pigments are known to be responsible for seed colour, an anthocyanin and a melanin-1ike pigment. These pigments may occur in the hulls, pericarp, aleurone layer and occasionally deeper in the endosperm. Colour may develop independently in each of these parts of the barley grain. The colour developed at maturity may be black, blue, purple, red, yellow, grey, white or an intergrade of these. The resulting colour depends upon the pigments present, their location in the different parts of the grain and the level of pigment deposition. The colour produced by the anthocyanins depends on the $\mathrm{pH}$ of the tissue where the pigment is developed (Harlan,1914; Mullick et al.,1958).

Colour in oats is confined to the lemma and palea, the caryopsis having no influence on the final seed colour (Hunter,1924). No report 
could be found in the literature concerning the chemical nature of the pigments involved.

In oats, five distinct classes of colour have been recognized: black (including dark brown), grey, red, yellow and white (Stanton, 1961). These five basic lemma colours are fairly stable. However the expression of this character is greatly influenced, even sometimes, obscured by the degree of maturity of the plants and by external conditions such as the degree of weathering (Jensen,1961). In addition, genetic factors and gene interactions are responsible for the range of colour variation occurring within each class, making clear-cut distinctions between classes difficult to differentiate.

\section{Inheritance of Lemma Colour}

Lemma colour is one of the most obvious characters in oats and it has been extensively studied genetically. Jensen(1961) made a review of 1iterature on the inheritance of this kernel character from Rimpau who made the first report in 1891 to Coffman who published later in 1964 the results of a systematic study of lemma colour inheritance on 40 crosses ' involving all the possible combinations of the parental lemma colours.

Very early in the investigation of the genetics of lemma colour, it was observed that the classification of segregating populations presents many difficulties. As stated by Robb(1932) accurate identification of all the possible genotype colour groups was impossible due to the occurrence of a range of colours between two closely related shades of colour such as yellow and white. Many investigators bypassed this 
difficulty by grouping colour classes.

Numerous investigations have provided genetic evidence for the existence of factors controlling the expression of lemma colour. "A 1ist of 13 genes is presented in the catalogue of genes governing characters in oats (Simons et $\underline{\text { al }}, 1978$ ). Incomplete epistasis or the existence of modifying and intensifying genes was suggested as being responsible for the colour gradation observed between two colour classes.

No attempt will be made to duplicate Jensen's review of the literature. However, a review of the genes governing lemma colour in oats will be presented. A11 the different phenotypic ratios reported in the literature for each possible colour combination are summarized in Tables 1 to 4 .

\section{$\underline{\text { Black }}$}

Wilson(1904) reported data on a cross involving a black-seeded oat. He noted that the colour of the black parent, Black Tartarian, was dominant over lighter colours in a cross with a white oat. The $F_{1}$ was not as dark as Black Tartarian and the $\mathrm{F}_{2}$ progenies were classified in four colour groups, black, brown, yellow and white. He reported a ratio of 3 black-brown: 1 yellow-white suggesting that one completely dominant gene for black lemma colour was present in the genotype of the black parent.

As reported by Jensen(1961), Norton(1907) was able to distinguish between black and the dark brown progenies and reported a ratio of 1 black: 2 brown:1 white. Therefore, the black gene involved seems to be 
incompletely dominant over white. Black lemma colour is conditioned by the gene in its dominant homozygous condition, $\mathrm{BB}$, brown is the expression of the gene in its heterozygous condition, $\mathrm{Bb}$, and white is the result of the recessive homozygosity,bb. This gene, reported by Wilson," Norton and others, has been designated Lc-1 (Simons et al,1978).

According to Jensen(1961), the existence of a second gene conditioning black lemma colour was first reported by Nilsson-Eh1e(1909). From a black $X$ white cross, he obtained a ratio of 15 black:1 grey-white but interpreted it as a trihybrid ratio(60:4). He concluded that the black parent carried two genes for black, $S_{1}$ and $S_{2}$ and one gene for grey, Gr. Robb(1932), Coffman(1964) and McKenzie and Fleischmann (1964) also reported data supporting Nilsson-Ehle's discovery. This gene has been assigned the symbol Lc-3 (Simons et al,1978).

A11 results obtained from crosses involving a black-seeded parent indicate that black lemma colour is epistatic over the other four colour classes, grey, red, yellow and white(Table 1).

Jensen(1961) reported Meurman's suggestion that the dark lemma colour(black) would be conditioned by a basic dark colour factor grey(Gr) whose effect is deepened by the action of the colour strengthening factor designated $Z$. These two genes have been resymbolized $\mathrm{Lc}-2$ and En-Lc-2 respectively (Simons et al,1978).

Grey

Nilsson-Ehle(1909, see Jensen,1961) reported the existence of a gene conditioning grey lemma colour. In the progenies of crosses involving 
TABLE 1. Segregation ratios for each colour combination involving black lemma colour

\begin{tabular}{|c|c|c|c|}
\hline COLOUR COMBINATION & $\begin{array}{l}\text { F's } \\
\text { COLOUR }\end{array}$ & $\begin{array}{l}\text { F 's segrega- } \\
\text { gation ratio }\end{array}$ & REFERENCES \\
\hline Black X Black & black & al1 black & Coffman(1964) \\
\hline \multirow[t]{7}{*}{ Black X Red } & - & $\begin{array}{l}72 \% \text { coloured: } 28 \% \\
\text { uncoloured }\end{array}$ & Wakabayashi(1921) \\
\hline & black & $\begin{array}{l}3 \text { black: } 1 \text { non- } \\
\text { black }\end{array}$ & Coffman(1964) \\
\hline & black & 3 black: 1 red & $\begin{array}{l}\text { DeVillers }(1935) \S \\
\text { Tang(1938)§ }\end{array}$ \\
\hline & - & $\begin{array}{c}12 \text { black: } 3 \text { grey } \\
1 \text { red }\end{array}$ & Coffman (1964) \\
\hline & - & $\begin{array}{c}12 \text { black:3 red:1 } \\
\text { grey }\end{array}$ & Coffman (1964) \\
\hline & - & $\begin{array}{c}9 \text { black: } 6 \text { red: } \\
1 \text { grey }\end{array}$ & Coffman (1964) \\
\hline & - & $\begin{array}{c}48 \text { black: } 15 \text { grey: } \\
1 \text { red }\end{array}$ & Coffman(1964) \\
\hline \multirow[t]{2}{*}{ Black X Grey } & black & 3 black: 1 grey & Coffman (1964) \\
\hline & - & $\begin{array}{c}12 \text { black:3 grey: } 1 \\
\text { yellow }\end{array}$ & $\operatorname{Ma}(1933) \S$ \\
\hline \multirow[t]{6}{*}{ Black X Yellow } & $\tan$ & $\begin{array}{c}3 \text { dark:1 light } \\
\text { coloured }\end{array}$ & Reed(1931) \\
\hline & ark brown & 3 black: 1 nonblack & $\begin{array}{l}\text { Love and Craig } \\
\qquad(1918 \mathrm{a})\end{array}$ \\
\hline & - & 3 black:1 yellow & $\operatorname{Ru}(1933) \S$ \\
\hline & - & $\begin{array}{c}12 \text { black: } 3 \text { yellow: } \\
1 \text { white }\end{array}$ & $\begin{array}{l}\text { Nilsson-Ehle } \\
(1909) \S\end{array}$ \\
\hline & - & $\begin{array}{c}12 \text { black: } 3 \text { white: } \\
1 \text { yellow }\end{array}$ & $\begin{array}{c}\text { Nilsson-Ehle } \\
(1909) \S\end{array}$ \\
\hline & t-reddish & $\begin{array}{c}12 \text { black: } 3 \text { grey: } \\
1 \text { yellow }\end{array}$ & $\begin{array}{l}\text { Surface (1916) } \\
\text { Coffman (1964) }\end{array}$ \\
\hline
\end{tabular}


Table 1(cont.)

\begin{tabular}{|c|c|c|c|}
\hline COLOUR COMBINATION & $\begin{array}{c}\mathrm{F} \text { 's } \\
\text { COLOUR }\end{array}$ & $\begin{array}{l}\mathrm{F} \text { 's segrega- } \\
\text { gation ratio }\end{array}$ & REFERENCES \\
\hline & $\begin{array}{r}\text { black } \\
- \\
3\end{array}$ & $\begin{array}{l}12 \text { black: } 3 \text { red } \\
48 \text { black: } 9 \text { grey+yellow: } \\
\text { grey: } 3 \text { yellow: } 1 \text { white }\end{array}$ & $\begin{array}{l}\text { Middleton(1938) } \\
\text { Nilsson-Ehle } \\
\qquad(1909) \S\end{array}$ \\
\hline & - & $\begin{array}{c}48 \text { black: } 12 \text { grey: } 3 \\
\text { bronze-red: } 1 \text { yellow: }\end{array}$ & $\operatorname{Coffman}(1964)$ \\
\hline \multirow[t]{7}{*}{ Black X White } & brown & 3 black: 1 white & $\begin{array}{c}\text { Nilsson-Ehle } \\
\text { (1909)ह }\end{array}$ \\
\hline & brown & $\begin{array}{l}3 \text { black-brown: } 1 \\
\text { yellow-white }\end{array}$ & Wilson(1904) \\
\hline & brown & $\begin{array}{c}1 \text { black: } 2 \text { brown: } \\
1 \text { white }\end{array}$ & Norton $(1907) \S$ \\
\hline & - & $\begin{array}{c}12 \text { black: } 3 \text { grey: } \\
1 \text { white }\end{array}$ & $\begin{array}{l}\text { Nilsson-Ehle } \\
\quad(1909) \S \\
\text { Welsh }(1931) \\
\text { Philp }(1933)\end{array}$ \\
\hline & - & $\begin{array}{c}60 \text { black: } 3 \text { grey: } \\
1 \text { white }\end{array}$ & $\operatorname{Robb}(1932)$ \\
\hline & - & 60 black:4 grey-white & $\begin{array}{c}\text { Nilsson-Ehle } \\
(1909) \S\end{array}$ \\
\hline & - & $\begin{array}{l}48 \text { black: } 12 \text { grey: } \\
3 \text { yellow: } 1 \text { white }\end{array}$ & Coffman(1964) \\
\hline $\mathrm{BCF}$ & families & $\begin{array}{c}2 \text { black: } 1 \text { grey: } \\
1 \text { white }\end{array}$ & $\begin{array}{c}\text { Kiehn et a1 } \\
(1976)\end{array}$ \\
\hline $\mathrm{BCF}$ & families & 1 seg: 1 nonseg & Wong(1981) \\
\hline
\end{tabular}

cited by Jensen(1961) 
black and white oats, he obtained grey segregates (ratio of 15 black:1 grey-white and 12 black:3 grey:1 white). He concluded that the gene for grey(Gr) present in the genotype of some of his black parents was expressed only in the absence of the genes $S_{1}$ or $S_{2}$ (genes conditioning black lemma colour). Simons et al(1978) assigned the symbol Lc-2 to this gene.

Two reports suggest the existence of different types of grey. Jensen(1961) cited the work of Akerman and Bader who observed two types of grey in the $\mathrm{F}_{2}$ and $\mathrm{F}_{3}$ populations. The two types were designated GreyI $\left(G_{I}\right)$ and GreyII( $\left.G_{I I}\right)$. They reported the gene for black colour epistatic to $G_{I}$ and $G_{I I}$ and $G_{I}$ epistatic to $G_{I I}$. The triple recessive was white.

Later Coffman(1964) studied the combination grey X grey and obtained two types of segregation ratio, 15 grey: 1 yellow and 63 grey:1 yellow. From these results, he concluded that the grey parents used were of three different types:(1) those with the factor GG as in the variety Cornellian; (2) those with the factor $G_{1} G_{1}$ as in the variety Garton Gray and (3) those with two factors for $\operatorname{grey}\left(\mathrm{G}_{2} \mathrm{G}_{2}\right)$ as found in Avena fatua.

The presence of an inhibitory gene for yellow in the genotype of certain grey-seeded cultivars of oats was proposed by Coffman(1964). He crossed Cornellian, a grey oat known to carry also a factor for grey(G) and a factor yellow, and Garton Gray that carries a different factor for grey $\left(G_{1}\right)$. A smaller number of yellow progenies than expected was found in the $\mathrm{F}_{2}$ population. He suggested that Garton Gray carries a factor inhibiting yellow or no yellow factor. 
Wong(1981) found that grey lemma colour was controlled by two genes in CAV 4656(1ight-medium grey), an A.sterilis accession. The backcross families segregated with a ratio of $3: 1$. The dark grey colour of CAV 4248 was controlled by a single gene as demonstrated by the $1: 1$ segregation ratio obtained in the backcross $\mathrm{F}_{2}$ families.

In general, grey is hypostatic to black, epistatic over yellow and white and either epistatic or hypostatic over red. The ratio 48 black: 12 grey:3 yellow: 1 white supports the first two statements (Coffman, 1964). His ratios for black $X$ red crosses (eg.12 black:3 grey:1 red and 12 black:3 red:1 grey) indicated the possible existence of different factors for both grey and red and their interaction with each other.

Table 2 presents a list of the phenotypic ratios reported in the literature for all possible colour combinations involving grey-seeded oat parents except the black $X$ grey combination.

$\underline{\text { Red }}$

According to Jensen(1961), several workers reported the existence of . a gene conditioning red lemma colour. Wiggans(see Jensen,1961) studied the progenies of the cross Red Texas(red) X Swedish Select(white) and observed that the $F_{1}$ had lemmas of a lighter red colour than the red parent. Four colours were found in the $F_{2}$ population: red, grey, yellow and white. He grouped them into reds(68) and nonreds(23) which suggests a $3: 1$ relationship.

Fraser(see Jensen,1961) crossed a du11 yellowish red-seeded oat(Burt) with Sixty Day(ye11ow) and obtained a phenotypic ratio of 48 
TABLE 2. Segregation ratios obtained for each colour combination involving grey lemma colour

\begin{tabular}{|c|c|c|c|c|}
\hline COLOUR & COMBINATION & $\begin{array}{l}\mathrm{F}_{1} \text { 's } \\
\text { COLOUR }\end{array}$ & $\begin{array}{l}\mathrm{F}_{2} \text { 's segrega- } \\
\text { gation ratio }\end{array}$ & REFERENCES \\
\hline Grey X & Black & & Table 1) & \\
\hline \multirow[t]{2}{*}{ Grey X } & Grey & - & 15 grey: 1 yellow & Coffman (1964) \\
\hline & & & 63 grey: 1 yellow & Coffman (1964) \\
\hline \multirow[t]{2}{*}{ Grey X } & Red & - & 3 red:1 grey & $\begin{array}{l}\text { Florel1 (1931) } \\
\text { Coffman (1964) }\end{array}$ \\
\hline & & & 13 grey: 1 red & Coffman(1964) \\
\hline \multirow[t]{3}{*}{ Grey X } & Ye11ow & - & dihybrid & $\begin{array}{l}\text { Nilsson-Ehle } \\
\quad(1909) \S\end{array}$ \\
\hline & & & 3 grey: 1 yellow & Coffman(1964) \\
\hline & & & 13 grey: 1 yellow & Coffman(1964) \\
\hline \multirow[t]{7}{*}{ Grey X } & White & - & 3 grey: 1 white & $\begin{array}{l}\text { Nilsson-Ehle } \\
\text { (1909)§ }\end{array}$ \\
\hline & & & & Coffman(1964) \\
\hline & & grey & $\begin{array}{l}12 \text { grey: } 3 \text { red: } \\
1 \text { white }\end{array}$ & Hennings $(1924) \S$ \\
\hline & & - & $\begin{array}{c}12 \text { grey: } 3 \text { yellow: } \\
1 \text { white }\end{array}$ & $\operatorname{Coffman}(1964)$ \\
\hline & \multicolumn{2}{|c|}{$\mathrm{BCF}_{2}$ families } & 1 grey:1 white & $\begin{array}{l}\text { Kiehn et a1 } \\
\quad(1976)\end{array}$ \\
\hline & \multirow{2}{*}{\multicolumn{2}{|c|}{$\mathrm{BCF}_{2}$ families }} & 3 seg:1 nonseg & Wong(1981) \\
\hline & & & 1 seg:1 nonseg & Wong (1981) \\
\hline
\end{tabular}

§cited by Jensen(1961) 
red:15 yellow: 1 white. He suggested that a factor for $\operatorname{red}(R)$ and two factors for yellow, $Y$ and $Y^{\prime}$ were involved. This gene for red lemma colour was redesignated Lc-6 by Simons et al.(1978).

Cotner(1929, see Jensen,1961) and Coffman(1964) found a second gene for red lemma colour. Cotner crossed red A.sterilis var. Ruvia with A.sativa var. Upright (white-seeded). The observed segregation ratio fitted a 63 red+yellow: 1 white ratio. He concluded that the red parent carries two factors for red and 1 factor for yellow. Coffman reported a ratio of 60 red:3 yellow: 1 white for a cross red $X$ white involving Fulghum fatuoid.

As mentioned previously, red is hypostatic to black and either epistatic or hypostatic to grey. In all cases where red, yellow and/or white segregates are involved, the phenotypic ratios demonstrate that red is epistatic over yellow and white. (Table 3)

\section{Yellow}

Nilsson-Ehle(1909, see Jensen,1961) discovered a factor responsible for yellow lemma colour. He made 10 crosses between yellow and white parents and observed that the colour of the $F_{1}$ 's varied from yellowish shades to white. $F_{2}$ progenies were classified as yellow-yellowish or white. The overall total for the 24 families examined was 1,219 yellow-yellowish:1,368 white. He studied the $F_{3}$ generation of two $F_{2}$ families. One of the families gave a segregation ratio of 41:84:35 suggestive of a 1:2:1 relationship. From this, Nilsson-Ehle concluded 
TABLE 3. Segregation ratios for each colour combination involving red lemma colour

\begin{tabular}{|c|c|c|c|}
\hline COLOUR COMBINATION & $\begin{array}{c}\text { F.1's }_{1} \\
\text { COLOUR }\end{array}$ & $\begin{array}{l}\mathrm{F}_{2} \text { 's segrega- } \\
\text { gation ratio }\end{array}$ & REFERENCES - \\
\hline Red X Black & \multicolumn{2}{|c|}{ (see Table 1) } & \\
\hline Red X Grey & \multicolumn{2}{|c|}{ (see Table 2) } & \\
\hline Red X Red & - & al1 red & Coffman (1964) \\
\hline \multirow[t]{2}{*}{ Red X Yellow } & \multirow[t]{2}{*}{-} & $\begin{array}{r}12 \text { red:3 reddish } \\
\text { grey: } 1 \text { yellow }\end{array}$ & Coffman (1964) \\
\hline & & 15 red:1 yellow & Coffman(1964) \\
\hline \multirow[t]{4}{*}{ Red $\mathrm{X}$ White } & light-red & 68 red:23 nonred & Wiggans $(1918) \S$ \\
\hline & light-red & 63 colored: 1 white & Cotner $(1929) \S$ \\
\hline & \multirow[t]{2}{*}{ - } & $\begin{array}{l}48 \text { red:12 grey: } \\
3 \text { yellow: } 1 \text { white }\end{array}$ & Coffman(1964) \\
\hline & & $\begin{array}{c}60 \text { red: } 3 \text { yellow: } \\
1 \text { white }\end{array}$ & Coffman(1964) \\
\hline
\end{tabular}

$\S$ cited by Jensen(1961) 
that one pair of alleles was involved, the heterozygote(Gg) being capable of showing a continuous series of colour shades between yellow and white. The symbol Lc-4 has been assigned to this gene (Simons et al.,1978). Surface(1916), Love and Craig(1918b), Torrie(1939), Coffman(1964) and others also provided evidences of the existence of this gene.

Fraser(1919, see Jensen,1961), in a study involving a dull yellowish-red oat(Burt) and the yellow-seeded cultivar Sixty Day, discovered a second gene conditioning yellow lemma colour. The observed phenotypic ratio gave a good fit to a 48 red:15 yellow: 1 white relationship. Fraser assumed two factors for yellow, $Y$ and $Y^{\prime}$, and one factor for $\operatorname{red}(R)$. $R$ is epistatic to both $Y$ and $Y^{\prime}$. This second gene was later renamed Lc-5 (Simons et al., 1978).

Coffman(1964) also obtained evidence of the existence of a second gene for yellow lemma colour. From the results of the cross Navarro(yellow) X Markton(yellow),(63 reddish-yellow:1 yellow) and other studies, Coffman concluded that Markton must carry a second factor for yellow different that the one in Navarro.

Two complementary factors, designated Lc-10 and Lc-11 (Simons et al,1978) have been reported by ko et al(1946). They studied the inheritance of lemma colour in a cross between S.D.334, a yellowish-white A.sativa variety and Bond; a light reddish-brown A.byzantina variety. Classification of the $\mathrm{F}_{3}$ lines gave a ratio of 7 yellow to white: 8 segregating:1 reddish-brown. The authors concluded that two complementary factors conditioning white to yellowish lemma colour were carried in the dominant homozygous condition in S.D.334 and in the 
recessive condition in Bond.

An unusual ratio of 63 reddish-yellow: 1 yellow was obtained by Coffman(1964) from a cross involving two yellow-seeded parents. "Coffman suggested that a modifying factor or factors were present in the genotype of varieties Navarro and Markton in addition to the factor conditioning yellow lemma. These factors intensify the yellow colour and are responsible for progenies that closely approach red in colour.

Yellow has been shown to be hypostatic to black, grey and red. It is either hypostatic or dominant over white. In all cases where the dominant genes for white lemma colour reported by Welsh(1931) were not present in the genotype of the parents, yellow is dominant over white. (Table 4)

White

Two dominant genes, Lc-8 and Lc-9(Simons et al, 1978), were found by Welsh(1931). In one of the four yellow $X$ white crosses studied, he obtained a ratio of 7 white: 8 segregating: 1 yellow in the $F_{3}$ generation. The results indicated that two factors with white being dominant were involved.

In relation to the other colour classes, white is always recessive, except when the dominant gene conditioning white lemma colour is present in the genotype. In this case, yellow is hypostatic to white.

Coffman(1964) studied the combination white $X$ white and concluded that the parents had a common genetic constitution. (Table 4). 
TABLE 4. Segregation ratios obtained for the three colour combinaisons yellow $X$ yellow, yellow $X$ white and white $X$ white

\begin{tabular}{|c|c|c|}
\hline COLOUR COMBINATION & $\begin{array}{l}\mathrm{F}_{2} \text { 's segrega- } \\
\text { gation ratio }\end{array}$ & REFERENCES * \\
\hline Yellow X Yellow & $\begin{array}{l}63 \text { reddish-yellow: } \\
1 \text { ye11ow }\end{array}$ & Coffman(1964) \\
\hline \multirow[t]{4}{*}{ Yellow X White } & $\begin{array}{r}\text { yellowish }\left(\mathrm{F}_{3}\right) 1 \text { yellow: } 2 \text { yel- } \\
\text { Iow-white:1 white }\end{array}$ & $\begin{array}{l}\text { Nilsson-Ehle } \\
\quad(1909) \S\end{array}$ \\
\hline & $\begin{array}{l}1 \text { white: } 2 \text { yellow- } \\
\text { white: } 1 \text { yellow }\end{array}$ & Welsh(1931) \\
\hline & white $\begin{array}{c}\left(\mathrm{F}_{3}\right) 7 \text { white: } 8 \text { seg: } \\
1 \text { yellow }\end{array}$ & We1sh(1931) \\
\hline & 3 yellow: 1 white & Coffman (1964) \\
\hline White X White & all white & Coffman (1964) \\
\hline
\end{tabular}

$\S$ cited by Jensen(1961) 


\section{Light-Brown}

Nishiyama(1934), as cited by Simons et al(1978) reported a gene(B1) for light-brown lemma colour in the progeny of A.barbata X A.strigosa. This gene appears to be epistatic over grey lemma colour of A.strigosa. The gene was assigned the standardized symbol of Lc-12 (Simons et a1, 1978).

Table 5 presents a list of the genes conditioning lemma colours in oats as reported by Simons et a1 (1978).

\section{Association Between Lemma Colour and Other}

\section{Characteristics}

Inheritance studies often provide information on linkage relationship i.e. the association in inheritance of certain genes located on the same chromosome (Rieger et al,1976). Tests for genetic linkage frequently provide evidence of gene independence.

\section{Lemma Colour and Morphological Kernel Characters.}

\section{Genetic Independence}

Genetic independence has been reported between lemma colour and the following kernel characteristics: type of basal articulation, awns, basal pubescence, dorsal pubescence, the naked character, and fatuoid type of grain (Jensen, 1961).

Kiehn et al(1976) found that the awned characteristic was inherited 
TABLE 5. Oat genes for lemma colour (Simons et al, 1978)

\begin{tabular}{|c|c|}
\hline GENE SYMBOL & DESCRIPTION AND MOST RECENT REFERENCE \\
\hline $\mathrm{Lc}-1$ & $\begin{array}{l}\text { Incompletely dominant gene for black } \\
\text { or dark lemma colour. (Coffman,1964) }\end{array}$ \\
\hline$L c-2$ & $\begin{array}{l}\text { Gene for grey lemma colour expressed } \\
\text { only in the absence of black. Design- } \\
\text { ated "Gr". (Coffman, 1964) }\end{array}$ \\
\hline En-Lc-2 & $\begin{array}{l}\text { Gene that intensifies grey lemma co- } \\
\text { lour in the presence of Lc-2. Designated } \\
\text { "Z". (Meurman,1927)§ }\end{array}$ \\
\hline$L c-3$ & $\begin{array}{l}\text { Second gene for black lemma colour. } \\
\text { Designated S2. (Coffman,1946) }\end{array}$ \\
\hline$L c-4$ & $\begin{array}{l}\text { Gene for yellow lemma colour. } \\
\text { Designated "G". (Coffman,1946) }\end{array}$ \\
\hline$L c-5$ & $\begin{array}{l}\text { Second gene for yellow lemma colour. } \\
\text { Designated "Y". (Fraser,1919) } §\end{array}$ \\
\hline$L c-6$ & $\begin{array}{l}\text { Gene for red lemma colour. Designated } \\
\text { "R". (Coffman,1946) }\end{array}$ \\
\hline $\mathrm{Lc}-7$ & $\begin{array}{l}\text { Second gene for red lemma colour. } \\
\text { (Coffman,1946) }\end{array}$ \\
\hline $\mathrm{Lc}-8$ & $\begin{array}{l}\text { Dominant gene for white lemma colour. } \\
\text { (Welsh,1931) }\end{array}$ \\
\hline$L c-9$ & $\begin{array}{l}\text { Second dominant gene for white lemma } \\
\text { colour. (Welsh,1931) }\end{array}$ \\
\hline $\mathrm{Lc}-10$ & $\begin{array}{l}\text { Complementary gene conditioning with } \\
\text { Lc-11 white to yellowish lemma colour. } \\
\text { (Ko et al, 1946) }\end{array}$ \\
\hline$L c-11$ & $\begin{array}{l}\text { Complementary gene conditioning with } \\
\text { Lc-10 white to yellowish lemma colour. } \\
\text { (Ko et al,1946) }\end{array}$ \\
\hline Lc -12 & $\begin{array}{l}\text { Gene for 1ight-brown lemma colour. } \\
\text { (Nishiyama,1934)§ }\end{array}$ \\
\hline
\end{tabular}

$\S$ cited by Simons et al . (1978) 
independent1y from black lemma colour in the cross Pendek (white) X CAV 4963 (black).

\section{Linkage Relationship}

Basal articulation. Wilds(1917, see Jensen,1961) reported linkage between lemma colour and basal articulation. He found a negative correlation between fatua type of articulation and yellow lemma colour. In a cross of A.sativa X A.sterilis, Middleton(1938) concluded that the sterilis "sucker" base character is closely linked with red lemma colour.

Awns(inhibitor). Love and Fraser(1917), Love and Craig(1929) and according to Jensen(1961), other workers reported a relationship between the development of yellow colour and the degree of awning. The factor responsible for yellow lemma colour seems to be closely linked with an inhibitory factor that limits awn development. Smith(1934, see Jensen,1961) suggested that the awn complex of length, strength and presence is associated with genes for dark lemma colour. Kiehn et al(1976) had reported that the genes for grey lemma colour and wild type

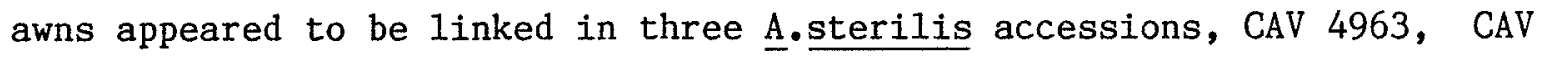
1358 and CAV 1376. Wong(1981) reported a similar association between strong awns and grey lemma colour in another A.sterilis accession, CAV 4248 .

Pubescence. Linkage between black lemma colour and dorsal lemma pubescence on the lower grain has been reported in A. fatua by Surface(1916) and Aamodt et al(1934) and in A.sterilis Ludoviciana by Middleton(1938). In A. fatua, Love and Craig(1918a) found two factors for 
pubescence, one linked with black colour and the other independent of colour factors. Philp(1933) also reported linkage between the gene conditioning black lemma colour $(B)$ and one of the two genes governing pubescence on the back of the lower grain(P).

Wilds(1917, see Jensen,1961), Love and Craig(1918a), Von Tschermak (1929, see Jensen,1961) and Smith(1934, see Jensen,1961) found partial or complete linkage between yellow lemma colour and glabrousness. The gene for yellow factor has either an inhibitory effect on lemma pubescence or is closely linked with an inhibitory factor.

Hairiness of the lemma and brown lemma colour were almost completely linked in an A.fatua X A.sterilis cross (F1ore11, 1931). Wong(1981) reported that the genes for dark brown lemma colour and lemma pubescence appeared to be either pleiotropic or closely linked in the cross CAV 4904 $X$ 'Sun $\mathrm{II}^{2}$ '. An association between grey lemma colour and lemma pubescence was reported in the cross CAV $4656 \mathrm{X}$ 'Sun $\mathrm{II}^{2}$ '.

\section{Genetic complexes}

Genetic complexes involving gene(s) for lemma colour have been reported. According to Jensen(1961), Jones and Von Tschermak reported complete or close coupling between sativa kernel type and yellow colour of the lemma. A linkage complex of genes controlling seven characters was found by Torrie(1939) in a cross of Iowa No.444 X Bond (A.byzantina). The characters linked were yellow lemma, basal articulation, hair number, awning, rachilla attachment, red lemma and hair length. Ko et al(1946) studied seven kernel characters in crosses of Bond with two A.sativa 
parents and found that the genes were all located on the same chromosome. They suggested that the order of genes was awning, twisted black base of awn, basal articulation, basal hair number, rachilla attachment, basal hair length and lemma colour.

Lemma Colour and Disease Resistance (Rust and Smut)

\section{Crown and Stem rust}

Forsberg and Nishiyama(1969) reported that genes conditioning black lemma colour and resistance to Puccinia coronata f.sp avenae Eriks. (crown rust) were linked in four $F_{6}$ lines derived from the oat cross derived-tetraploid C.I.7232 X A. sativa var.Clarion. A11 resistant plants had dark-coloured lemmas while susceptible plants had light-coloured lemmas.

McKenzie and Fleischmann(1964) reported independence between genes for black lemma colour and genes for seedling and adult crown rust resistance in two Israeli collections of A.sterilis.

McKenzie et al(1968) reported independence between genes for black and white lemma colours and rust resistance in their study of the association of stem rust( $\underline{\text {.graminis }}$ Pers.f.sp.avenae Eriks. and E.Henn.) and crown rust resistance in Jostrain, an A. sativa variety.

Kiehn et al(1976) investigated the association existing between resistance to crown rust and seed colour in four accessions of A.sterilis, CAV 4963(black), CAV 1358(grey), CAV 1376(grey) and CAV 1964(white). Results showed that the genes responsible for lemma colour 
and those conferring crown rust resistance segregated independently. Wong(1981) found no association between crown rust resistance and grey and dark brown lemma colours in three different A.sterilis accessions, CAV 4248, CAV 4656 and $\operatorname{CAV} 4904$.

Independence has been indicated between genes for lemma colour and reaction to certain stem rust races by Hayes et al(1928), Welsh(1931) and Smith(1934, see Jensen,1961).

$\underline{\text { Smut }}$

Wakabayashi(1921), in his study of the inheritance of smut resistance, stated:" There may also be a correlation between smut susceptibility and white colour of the floral glumes.". Garber et al(1929) reported an apparent linkage between a gene for black lemma colour and a modifying factor(or a group of factors) responsible for smut susceptibility.

Reed and Stanton(1925), Hayes et al(1928), Reed(1931), Coffman et al(1931), Johnson(1933) and Patel(1941, see Jensen, 1961) have reported genetic independence between the genes for smut reaction and those for lemma colour.

Lemma Colour and Grain Quality Characteristics

The relationship between lemma colour and the grain quality characters, test weight, hull percentage, protein and oil percent has been less frequently studied than the association with morphological kernel characters. However, since Murphy's report(USDA,1967) on the 
protein content of several A.sterilis selections, studies on the associations among traits in progenies from $\underline{A}$. sativa $X \underline{A}$. sterilis crosses began to appear in the literature. The objective was then to determine whether any easily classifiable morphological trait could serve as an index for selection of lines having a high protein percent.

Following is a review on the six quality characteristics investigated in this study. Pertinent information concerning each character and a review of literature on their relationship with lemma colour is presented.

\section{Test Weight}

The character test weight estimates the weight of a fixed volume of grain. It is a measure of packing density and consequently is of value in storage and transportation. Oats exhibit the lowest test weight (42 $\mathrm{kg} / \mathrm{h} 1)$ in comparison to barley, wheat and corn $(60 \mathrm{~kg} / \mathrm{hl}, 75 \mathrm{~kg} / \mathrm{hl}$ and 70 $\mathrm{kg} / \mathrm{hl}$, respectively). This $10 \mathrm{w}$ test weight value is due to the bulky hulls of the oat grains.

A minimum test weight value has been determined for each grade defined in the Official Grain Grading Guide (Canadian Grain Commission, 1984) for the grading of Canadian oats. The oats graded No.1 Canada Western must have a test weight equal to or higher than $52 \mathrm{~kg} / \mathrm{h} 1$ to meet the standard of quality determined for this grade. Any oat sample having a lower test weight would be classified in a lower grade thus reducing the economic value. The oat breeding program aims to increase the test weight as much as possible while maintaining the level of the other 
desirable characteristics. This quality characteristic is inherited polygenically and high values of heritability $(0.62-0.88)$ estimated by variance components have been reported by Wesenberg and Shands(1973).

No report could be found in the literature concerning the relationship between lemma colour and test weight.

\section{Percent Hu11}

Percent hull is expressed as a percentage of the ratio of hu11 weight to total seed weight. Because the nutritional value is found in the oat groat, it is an important grain quality characteristic when considering oats for either feed or food purposes. In both cases, low percent hull is desirable.

Total energy content is a major factor to consider in the choice of grain for feed purposes. Due to their high fibre content, hulls reduce the total energy content of the oat grain making oats less advantageous compared to other cereal grains. The breeder can improve the total energy content of the oat kernel by either reducing the percent hull or increasing the oil content.

Hulls are of low nutritional value, tough and fibrous and quite inedible by humans. Therefore for food purposes, the hulls must be removed during the manufacture of edible products. The hull percentage, inversely related to groat percentage, is the most influential factor affecting milling efficiency. Hull percentage therefore should be as low as possible. Hulless oats would be the best oat for milling purposes. However, problems in storage of this type of oats have not favoured its 
practical utilization.

Berry(1920) studied the association between lemma colour and several grain quality characteristics using 120 varieties of oats. He grouped the cultivars by colour of the grain (white, yellow, black or grey lemma), by thickness of the hull (thin, medium and thick) and by kernel size (sma11, medium and large). He observed that the lowest hull percentage was exhibited by the thin hull division of the black and grey grains.

Lyrene and Shands(1975) studied the associations among traits in $\mathrm{F}_{2}$ and $F_{3}$ progenies of six $\underline{A}$.sativa $X \underline{A}$.sterilis crosses in an attempt to determine whether desirable A.sativa traits can be maintained while selecting for high protein. The $F_{2}$ and $F_{3}$ plants were grouped according to lemma colour (white, grey, light-brown and dark brown) and were compared for mean expression of six quantitative traits. The results showed an association between white lemma colour and groat percentage with the white-lemma plants exhibiting a significantly higher groat percentage (lower hull percentage) than the other colour classes i.e. . grey, light-brown and dark brown.

Luby and Stuthman(1983) studied associations among agronomic, grain quality and seed morphology characters in progenies of eight A.sativa $X$ A.fatua crosses. They found that dark seed colour (grey, brown or red) and shattering were associated with lower groat percentage (higher hull percentage).

Inheritance of caryopsis and hull percentage has received little attention. Wesenberg and Shands $(1971,1973)$ studied segregating 
generations of seven oat crosses and suggested that several genetic factors influence caryopsis percentage and that the effects are additive. Heritability estimates ranged from 0.82 to 0.95 by the variance component method. Stuthman and Granger (1983) observed apparent differences in genetic systems. The results suggested partial dominance for high caryopsis percentage in population I (medium $X$ high cross), partial dominance for low caryosis percentage in population II (1ow X low cross) and an additive mechanism in population III (1ow X medium). They obtained heritability values of the same magnitude as those reported by previous workers.

\section{$\underline{\text { Protein Percent }}$}

Frey(1977) reviewed the literature on protein of oats and described the three unique features of this quality component of oats. First, oats is a very nutritious grain. Its biological value expressed in PER (protein efficiency ratio) is higher than that of corn, sorghum or wheat. This is due to the low proportion of the prolamin fraction (alcoholsoluble protein fraction) in the oat protein. The percentage of avenin (oat prolamin) varies from 12 to 20\%. The other cereals (wheat, barley and corn) have from 30 to $60 \%$ prolamin in the total protein fraction of the grain. The prolamin is very poor in the three essential amino acids, lysine, threonine, methionine and breeding efforts are concentrated on reducing its proportion in the other cereal grain proteins.

The second feature of the oat protein is that its biological value does not deteriorate as the protein content in the grain increases. As reported by Peterson(1976) the amino acid balance of oats remain rela- 
tively stable over a wide range of protein percentages. He showed that this was because the globulin (salt soluble protein) fraction, whose amino acid composition is similar to that of the total protein, increases more than the other fractions with increases in total protein. In contrast, in corn, barley or wheat, where the percentage of lysine and other essential amino acids declines (as percentage of total protein) because the proportion of prolamine increases with an increase in protein percentage. Robbins et al(1971) reported a low correlation between groat-protein percentages and Iysine percentages in the protein of oats.

Thirdly, the protein content of oat grain can be increased by genetic means. Studies of Robbins et al(1971), Frey(1973) and others demonstrated that a wide range of protein content is present in A.sativa species with a protein content as high as $21.9 \%$. A.sterilis species represents a very useful source of genes for high protein content with a mean protein content of $25.9 \%$ having been reported by Briggle et al(1975). The mean heritability for this character, overall studies, is 46\%. Therefore, the variability and heritability of protein content suggest that improvement should be successful through selection.

Frey(1977) summarized the information of the genetics of this characteristic in oats. He mentioned that protein percent seems to be inherited polygenically in crosses among strains of cultivated oats with partial dominance for low protein content in the $F_{1}$, but largely additive gene action in $\mathrm{F}_{2}$ and later generations.

A negative correlation found between protein percent and grain yield 
may slow down the progress in oat protein content improvement. However, Frey(1977) mentioned that the high protein-1ow yield relationships in oats are incorrect since genes for high grain protein haying no detrimental effect on yield have been discovered. Genes for high yield that have no effect on protein content have also been reported. The breeding objective is to increase the total protein yield. Grain protein percent seems to be inherited polygenically in crosses among strains of cultivated oats (Frey,1977).

These three characteristics of the oat protein give to this cereal the potential to become one of our most valuable foods.

Associations of percent protein with lemma colour have been reported by several authors. Berry(1920), in his study described previously, observed that the protein percent of the yellow-grain varieties was inferior to other colour classes i.e. white and black and grey. LeRoy et al(1974) used the $F_{5}$ generation progenies of $F_{4}$ plants from crosses between $\underline{A}$.sterilis cultivar Maxima Perez Lara and $5 \underline{A}$.sativa cultivars to study the relationships among factors involved in the improvement of oat quality. The partial regression coefficients obtained indicated high protein percent was significantly related to dark coloured lemmas $(r=0.19)$. They suggested that this kernel characteristic could be considered as a simple means of selection for protein percent. Campbell and Frey(1972) and Lyrene and Shands(1975) studied A.sativa X A.sterilis crosses and found high protein percent was associated with several undesirable spikelet characteristics (all A.sterilis traits) including shattering spikelets, awns and dark seed colours (brown and grey). However Luby and Stuthman(1983) reported that dark seed colour(grey, 
brown or red) and shattering were associated with lower groat protein percent in progeny of A.sativa X A.fatua crosses.

\section{Oil percent}

Kent(1975) presented the proximate fat content of cereal grains on a dry matter basis (Table 6). This shows that with the exception of sweet corn, oats(whole or dehulled) and millet exhibit a relatively higher oil content than the other cereals. Furthermore, oats is unusual among cereals because most of the oil is in the endosperm. This makes the oat flour particularly rich compared to other cereal flour (Key,1959).

The quantity and quality of oil have an effect on the suitability of oats for animal feed or for human nutrition. For animal feed, an increase in oil content would improve the caloric value of oats and thus makes this cereal more competitive as a component of feed formulas.

For human nutrition, the fatty acids composition of oil is of prime importance. Welch(1975) demonstrated the good quality of oat oil in a study of the fatty acid composition of six genotypes of oats and two of wheat and barley. He showed that the proportions of the three fatty acids, oleic, linoleic and linolenic were better in oats than in wheat and barley because the oleic acid constitutes a higher porportion in the oat oil. However, a major increase in oil content in the oat grain might impair its use for processing and its quality during storage because of rancidity problems caused by high free fatty acid levels. For these reasons, oats with less than $7 \%$ oil have been preferred by human-food processors. Frey and Hammond (1975) suggested that it may be possible to 
TABLE 6. Proximate fat content of cereal grains (dry matter basis) after Kent(1975)

\begin{tabular}{|c|c|}
\hline CEREAL & FAT PERCENTAGE \\
\hline $\begin{array}{l}\text { Wheat } \\
\text { Manitoba } \\
\text { English }\end{array}$ & $\begin{array}{l}2.9 \\
2.6\end{array}$ \\
\hline $\begin{array}{l}\text { Maize } \\
\quad \text { flint } \\
\text { dent } \\
\text { sweet }\end{array}$ & $\begin{array}{l}4.9 \\
4.6 \\
9.1\end{array}$ \\
\hline Sorghum & 3.6 \\
\hline Millet & 5.4 \\
\hline Rye & 1.4 \\
\hline Barley & 1.8 \\
\hline $\begin{array}{l}\text { Rice } \\
\text { paddy } \\
\text { brown } \\
\text { polish }\end{array}$ & $\begin{array}{l}2.2 \\
2.7 \\
0.5\end{array}$ \\
\hline $\begin{array}{l}\text { Oats } \\
\text { whole grains } \\
\text { groats }\end{array}$ & $\begin{array}{l}5.2 \\
7.0\end{array}$ \\
\hline
\end{tabular}


solve the rancidity problem by reducing the lipase activity either through breeding or post-harvest processing.

Improvement of the oil content by selection is possible. Oats show considerable genetic diversity affecting oil content. Brown and Craddock(1972) have examined over 4000 entries in the World Collection and have found groat oil contents from 3.1 to $11.6 \%$ with over $90 \%$ of the samples having 5 to $9 \%$ oil. Variability has been found among wild oat species as well (Frey and Hammond,1975). This grain quality characteristic is highly heritable as reported by Brown et al(1970) who estimated the heritability of oil content at 75-79\%. Baker and McKenzie(1972) reported high heritability values(68 to $93 \%$ ) in 13 crosses made among high-, medium-, and low-oil cultivars. One cross between sister cultivars gave a very low heritability value(18\%). Oil content is inherited polygenically (Frey and Hammond,1975).

Nonsignificant negative correlation between protein percent and oil percent has been reported by Forsberg et al(1974) and others and no significant undesirable correlations seem to exist between oil percent and oil quality, groat yield and groat weight. Baker and McKenzie(1972)' found that oil content was not significantly correlated with kernel weight, kernel density or hull percentage.

Breeding for oil percent requires laboratory oil percent determinations which are expensive and time consuming. It would be useful to have a highly-visible trait of neutral or positive value associated with high oil percent which could serve as an index for selection. Berry(1920), in his study previously described, reported that the highest 
percent oil was found in the thin hull division of the black and grey class. Luby and Stuthman(1983) reported an association between dark seed colour, shattering spikelets and lower groat oil percent in A.sativa X A.fatua crosses. No further investigations on the association of lemma colour and oil content have been reported.

\section{Kerne1 weight}

The character kernel weight is a measure of the weight of a given number of kernels and gives a rough idea of the size of the seeds. It is an important component of yield. Sampson(1971) estimated the heritabi1ity (narrow sense) of this quantitative trait at $74 \%$.

No report could be found in the literature concerning the relationship between lemma colour and kernel weight.

\section{Post-harvest dormancy}

Yield losses can result from post-harvest sprouting of the grain in the swathed oats when the conditions are favorable for germination. In addition to yield losses, the grain quality is affected. In these conditions, post-harvest dormancy or delayed germination would be very desirable.

Dormancy could be defined as a block to germination in a normal, mature grain placed in optimal germinative conditions (Gordon,1979). This is to distinguish from absence of germinative responses at the time of testing due to immaturity. 
Coffman and Frey(1961), in their review of literature on dormancy in oats, concluded that dormancy is a character inherent in the species or variety and does not appear to be associated with any morphologic characters of the seed. However, Coffman and Stanton(1938) who tested 25 different oat varieties representing six species, reported that the dark-coloured varieties appeared more frequently to have delayed germination. Only the black and red varieties in the cultivated oats were classified as having delayed germination i.e. they did not germinate effectively until about two months after harvest.

\section{Associations Found in Other Species}

Associations between seed colour and grain quality characteristics have been reported in other crop species. Four examples will be presented in this section to show the practical use of such relationships.

In wheat, a positive association has been found between grain colour and resistance to post-harvest sprouting. McEwan(1975), one of those who studied this relationship, reported that the red-grained group had higher initial seed dormancy, a lower tendency for sprout damage, a greater capacity to maintain test weight, less visible sprout damage to the grain and higher seed viability under sprouting conditions than do similar varieties with white grain. These results supported the commonly used practice of selecting for sprouting resistance amongst the red-grained lines.

Leisle et al(1981) studied lines of durum wheat (Triticum turgidum 
L.) for white glume colour, gluten strength and banding of gliadin proteins. Their results showed a linkage of factors controlling glume colour and gliadin proteins. Gluten strength appeared to be associated with these two characteristics. They have stressed the importance of this relationship in a plant breeding program aiming to select cultivars with strong gluten characteristics.

The third example concerns the breeding of turnip rape (Brassica campestris L.). Jonsson(1977) reported the association of seed colour and quality of rape and suggested the use of yellow seed colour to directly select lines having high protein and oil content and lower crude fibre content in the rape meal. This is now a common practice.

CuIbertson and Kommedah1(1956) studied the effect of seed coat colour on other characters in flax using the isogenic line technique. Their results showed that there was an association between yellow seed colour and high oil content and high iodine number of the oil. Yellow-seeded 1ines were also higher in 1,000 kernel weight and amount of seed damage but lower in test weight and seed yield than the brown-seeded 1ines. 
EFFECT OF LEMMA COLOUR ON GRAIN QUALITY

IN OATS, AVENA SATIVA L.

\author{
A. Plourde, R.I.H. McKenzie and P.D. Brown \\ Agriculture Canada Research Station, 195 Dafoe Road, \\ Winnipeg, Manitoba, Canada R3T 2M9
}

Will be Submitted to the Canadian Journal of Plant Science 


\section{EFFECT OF LEMMA COLOUR ON GRAIN QUALITY}

IN OATS, AVENA SATIVA L.

\section{Abstract}

The effect of oat lemma colour on grain quality was studied through the use of $\mathrm{F}_{3}$ derived near-isogenic $\mathrm{F}_{6}$ lines of contrasting lemma colours. Red lemma colour was associated with a lower hull percent and a lower test weight in comparisons with white or yellow lemmas. In 1984, the average difference of $1.17 \%$ hull between the white and red nearisogenic lines represented $4.4 \%$ improvement over the mean percent hull of the white-seeded lines. The red-seeded lines were significantly lower in percent hull in 30 out of the 36 pairs. Genetic possibilities to account for this result are discussed and include pleiotropism or a close linkage between the gene for red colour and a gene for low percent hull. A significant difference of 0.73 and $0.74 \mathrm{~kg} / \mathrm{hl}$ in test weight was obtained in the white versus red and yellow versus red comparisons respectively. The association of lemma colour and percent hull appeared to be stronger than the association of lemma colour and test weight suggesting that it would be easier to select red-seeded oat lines with a low percent hull and high test weight than white-seeded line having a low percent hull and high test weight.

Although showing no differences in 1983, white oats were of higher quality in 1984 with a significantly lower percent hull (-1.70\% hull) and 
a significantly higher test weight $(+2.29 \mathrm{~kg} / \mathrm{hl})$ when compared with their near-isogenic yellow-seeded lines. Black lemma colour seems to be associated with lower overall quality $(2.12 \%$ hul1 higher and $2.29 \mathrm{~kg} / \mathrm{hl}$ lower in test weight) in comparison to the other colour classes.

Red lemma colour could serve as an index to select high quality oats. No associations were found between lemma colours and the agronomic characters studied so that it should be possible to select for yield, short straw and maturity within any hull colour class.

\section{Introduction}

In western Canada, oat varieties have white lemmas because of traditional preferences expressed by the growers and millers for white oats. However, it has been observed that red oats may be of higher quality than white oats suggesting that there may be an association between lemma colour and grain quality characteristics. The existence of such an association would have important implications for selection of higher quality oats since an easily classifiable, visible trait could serve as an index for selection of a less-visible characteristic for which ex-' pensive and time consuming laboratory determinations are required. Moreover, it would revolutionize oat production if, for example, dark lemma colour was associated with a very desirable characteristic.

Associations between lemma colour and some grain quality characteristics have been reported in the literature. In Avena sativa L. X $\underline{A}$. sterilis L. progeny populations, Lyrene and Shands(1975) found associations between white lemma colour, low percent hull and low percent 
protein in the groat. Associations between dark lemma colour (black, dark brown and grey) and high percent protein have also been reported in A.sativa X A.sterilis progeny (Campbell and Frey,1972; LeRoy et a1,1974; Lyrene and Shands,1975). Luby and Stuthman(1983) reported that dark seed colour (grey, brown or red) was associated with lower groat percentage (higher percent hul1), lower groat protein percent and lower groat oil percent in A.sativa $X$ A. $\underline{\text { fatua }}$ L. progeny populations. No genetic information regarding the influence lemma colour might exert on other quality traits such as test weight, 1000 kernel weight or post-harvest dormancy has been reported.

Associations of this type have been found in other crops. In bread wheat, red kernel colour is currently used as an index for selection of pre-harvest sprouting resistance (Gordon,1979). In durum wheat, preliminary results suggested the existence of a strong association between white glume colour, gliadin proteins and possibly gluten strength (Leisle et al, 1981). In turnip rape, yellow seed colour is used to directly select lines having high protein and oil percentage in the seed and low percent crude fiber in the meal (Jonsson,1977). In flax, there is an association between yellow seed colour and high oil content, high iodine number of the oil, high 1000 seed weight, high amount of seed damage, low test weight and low yield (Culbertson and Kommedah1,1956).

The present study is the first attempt to study the effect of lemma colour on grain quality in the cultivated oat, A.sativa through the use of near-isogenic lines. This paper reports the results obtained for the grain quality characteristics, percent hull, percent protein, percent oil, test weight, 1000 kernel weight and post-harvest dormancy. The 
influence of lemma colour on the agronomic characters heading date, plant height and yield was also investigated.

Materials and Methods

Effect of lemma colour, kernel type and environment on percent hull of oats

In an attempt to obtain information on the effect of year and location on percent hull, a study was conducted using seed samples of four sister lines of A.sativa (i.e. derived from the same $F_{3}$ plant) in the $F_{10}$ and $F_{11}$ generation grown in oat yield trials in 1982 and 1983 respectively at Glenlea, Morden, Portage La Prairie and Brandon, Manitoba and Saskatoon, Saskatchewan. The lines, Dumont and OT 233, have white lemmas and the lines, OT 224 and OT 234, have red lemmas. Percent hull was determined on one-gram samples of both, primary and secondary kernels. Percent hull was determined by manually dehulling the kernels. and was expressed as a percentage of the ratio of hull weight to the total seed weight. Data were combined to provide information on percent hull of a random sample of seeds assuming that the proportion of primary and secondary kernels in such a sample would be 58:42 on a weight basis (average value of four lines grown at three locations in 1982) or $1: 1$ numerically. A factorial analysis using locations as replication was used to analyse the data.

Effect of lemma colour on grain quality in oats

Oats are generally grouped into five distinct lemma colour classes 
which are black (including dark brown), grey, red, yellow and white. Pairs of $\mathrm{F}_{3}$ derived near-isogenic $\mathrm{F}_{6}$ lines of contrasting lemma colour i.e. white versus red, yellow versus red, yellow versus white and black versus non-black were selected from the segregating generations of crosses according to the procedure described by Atkins and Mangelsdorf(1942). The material was visually classified for lemma colour using seeds of the parents (known colour) as a guide.

The selection began with the $\mathrm{F}_{3}$ generation grown at Glenlea, Manitoba in the summer of 1982. The soil type is Red River heavy clay. For the white versus red study, selection was made among $\begin{array}{llll}56 & F_{2} & \text { progeny }\end{array}$ plots of each of the following crosses:

CROSS

1 (Portmore X OT 233) X OT 224

2 (Etive X OT 233) X OT 224

3 (Levin $X$ OT 233) X OT 224

4 (Dula $\quad$ X OT 233) X OT 224

5 (Calibre X OT 233) X OT 224

The yellow versus red and yellow versus white pairs of near-isogenic lines were selected among the $200 \mathrm{~F}_{2}$ progeny plots of one cross, viz. (Lamar X OT 233) X OT 224. A description of the parents is given in Table 1. The material used in the black versus non-black study was selected from the segregating generations of black-seeded panicles found in the $F_{2}$ population of the three previously cited crosses involving the varieties Portmore, Levin and Lamar and three other crosses, viz. (West X OT 233) X OT 224, its reciprocal and (Moore X OT233) X OT 224. Selection began with 
$22 \mathrm{~F}_{3}$ plots. These black-seeded panicles are believed to be the result of outcrossing with Black Golden and Nip, two black-seeded varieties used in the border plots.

Selection in the $\mathrm{F}_{4}$ and $\mathrm{F}_{5}$ generations was done in greenhouses in the fall of 1982 and winter of 1983 respectively. The final selection of lines homozygous for lemma colour was done on the $F_{6}$ generation grown at Glenlea, Manitoba in the summer of 1983. Plots consisted of single rows, $1-m$ in length. The growing season was abnormally hot and dry in July and August and the material was also affected by stem rust (Puccinia graminis Pers.f.sp.avenae Eriks.and E.Henn.), crown rust ( $\underline{P}$. coronata f.sp. avenae Eriks) and barley yellow dwarf virus(BYDV). The whole plot of each selected line was hand-harvested and threshed mechanically. One panicle was kept apart and seeds sown in New Zealand in the winter of 1984 for seed increase purposes. One homozygous pair of near-isogenic $\mathrm{F}_{6}$ lines per $\mathrm{F}_{5}$ family was randomly choosen with a selection pressure on disease reaction so as to minimize differences in grain quality between the lines making up each pair. Of the 71 pairs selected, 36 were developed to compare white and red-seeded oats, 15 to compare yellow and red, 10 to compare yellow and white and 10 to study black versus non-black.

Data were recorded for percent hull of the primary kernels (using six $0.5 \mathrm{~g}$ subsamples). Percent hull was determined by manually dehulling the kernels and was expressed as a percentage of the ratio of hull weight to the total seed weight. Percent oil of whole grain sample (about $40 \mathrm{ml}$ ) was determined by the nuclear magentic resonance(NMR) technique (Robertson and Morrison,1980). Nitrogen analyses were performed by the Kjeldah1 method (AACC Method 46-12) using three 1-g subsamples of whole primary 
kernels of 22 and 11 pairs of the white versus red and yellow versus red lemma colour comparisons respectively. Due to short seed supply, nitrogen determination for the yellow versus white and black versus non-black comparisons was made on one $1-\mathrm{g}$ sample of whole primary kernels. The results were converted to percent protein by the formula of nitrogen $X$ 6.25. Groat protein percent was calculated by difference based on percent hull and percent protein data assuming $0 \%$ protein in the hull. A randomized complete block analysis (mixed model with sampling) and a paired t-test were used to analyse the data.

For the study on post-harvest dormancy, 10 seeds per line were sown in greenhouses in the winter of 1984 and plants were grown to maturity. Panicles were collected, air-dried four days at room temperature and stored at $-15^{\circ} \mathrm{C}$ until time to conduct germination tests. Ten pairs in the white versus red and yellow versus red comparisons and nine pairs in the two other lemma colour comparisons were randomly choosen. The panicles were mechanically threshed and 20 seeds per line $(10$ primary and 10 secondary kernels) were placed in 9-cm petri-dishes with two discs of filter paper (Whatman no.3). Five $\mathrm{ml}$ of distilled water were added (Day 0 ) and the dishes were placed in a room at constant temperature $\left(+15^{\circ} \mathrm{C}\right)$. On days 3 through 7 , the germinated seeds with radicles $1-\mathrm{cm}$ long were counted and discarded. Germination index (GI) and percent germination (PG) values were calculated as described by Hagemann and Ciha(1984). Number of days to reach maximum germination (DMG) was also calculated. A paired t-test was performed on these data.

A large-plot trial was conducted at Glenlea, Manitoba in the summer of 1984. The trial was grown in 6-row plots, $3.7 \mathrm{~m}$ long by $1.25 \mathrm{~m}$ wide. 
The number of pairs was $36,15,10$ and 7 in the white versus red, yellow versus red, yellow versus white and black versus non-black lemma colour comparisons respectively. The field design was a randomized complete block (pairs) using split plots for the paired near-isogenic lines with three replications except for the black versus non-black experiment which was replicated twice.

Data were recorded for heading date (days), plant height $(\mathrm{cm})$, yield (kg/ha), percent hull of the primary kernels (using $1-g$ sample), test weight $(\mathrm{kg} / \mathrm{hl})$ and 1000 kernel weight $(\mathrm{g})$. Data were analysed using a paired t-test and analysis of variance. For all lemma colour comparisons except black versus non-black, a completely randomized model with split plot was used to perform the analyses of variance because the third replicate of some of the pairs was missing. Two Isd values, one for the pairs with two replicates and one for those with three replicates, were derived from the ANOVA to compare the means of the near-isogenic lines within each pair.

\section{$\underline{\text { Results }}$}

Effect of lemma colour, kernel type and environment on percent hull in oats

In Table 2, the mean percent hull of the primary kernels, secondary kernels and of a weighed mixture of both kernel types (58:42) of four oat lines grown at five sites in each two years are presented. Results indicate significant differences between lines with a trend for the red-seeded lines to have a lower percent hull than the white-seeded 
lines. Primary and secondary kernels differed significantly in percent hul1. In terms of differences between lines, similar results were obtained by using primary kernels or a weighed mixture of both kernel types.

Analyses of variance of percent hull (Table 3) indicate that location and lines were sources of significant variation. Most of the variation among lines was associated with the white versus red comparison. Year had a significant effect on percent hull of the primary kernels only. A nonsignificant interaction of year with line was obtained in al1 three analyses.

Effect of lemma colour on agronomic characters in oats (1984)

Data recorded on the agronomic characters of the four colour comparison experiments are summarized in Table 4. No significant differences in heading date between lemma colours were found in the four experiments. Lemma colour had no significant effect on plant height except for the yellow versus white comparison. On an average, the yellow-seeded 1 ines were $1.59 \mathrm{~cm}$ higher than the white-seeded lines but differences were too small to be readily noticed in most cases. No significant differences in yield between lemma colours were obtained in the four experiments.

Analysis of variance revealed significant differences in heading date, plant height and yield between the near isogenic pairs in all colour comparisons in 1984. There was a significant pair X colour interaction in the white versus red seeded comparison for all three agronomic characters 
and in the black versus non-black comparison for only heading date. A1l the other pair $X$ colour interactions were not significantly different for the agronomic characters studied.

Effect of lemma colour on grain quality in oats

Data on the grain quality characteristics for the four lema colour comparisons are presented in Table 5.

\section{White versus Red}

The 1983 data showed that the white and red-seeded lines did not differ, on an average, in percent protein of the whole grain or groat and in percent oil of the whole kernel. However, there was a significant difference of $0.85 \%$ hull between the contrasting lemma colours. A significant difference of about the same magnitude (1.17\%) was obtained in 1984 . These overall significant differences represent $3.08 \%$ of the mean percent hull of the white-seeded lines in 1983 and $4.4 \%$ in 1984 . The red-seeded lines were significantly lower in percent hull in 16 out of the 36 pairs in 1983 and in 30 out of the 36 pairs in 1984. The lines of eight and one pairs showed the inverse significant relationship in 1983 and 1984 respectively.

A significant difference of $0.73 \mathrm{~kg} / \mathrm{hl}$ in test weight was obtained on 1984 samples between the white and red-seeded lines, the latter exhibiting a lower test weight. Sixteen out of the 36 pairs showed that the red-seeded lines were significantly lower than the white-seeded lines; three pairs showed a significant inverse relationship. 
No significant differences in 1000 kernel weight and the three sprouting parameters used to evaluate post-harvest dormancy were found.

The near-isogenic white and red-seeded lines were derived from five different crosses. The paired t-tests on percent hull for individual crosses indicate that in 1983, the difference of mean percent hu11 between lemma colours was not consistent from cross to cross. In 1984, however, al1 crosses but one, (Calibre X OT 233) X OT 224 (cross no 5), showed a significant difference with the red-seeded having, on an average, a lower percent hu11 (Table 6). Although the number of pairs was large enough to be able to statistically detect a difference of $1.0 \%$ hu11, a non-significant difference was obtained for the cross (Calibre X OT 220) X OT 224. One of the six pairs gave a negative difference $(-1.54 \%$ hu11). When the data were reanalyzed without this pair, the mean difference of $1.40 \%$ hull was significant at $1 \%$ level of probability.

The results of the paired t-tests on test weight performed by cross indicate that for 3 of the 5 crosses, white-seeded lines had a significantly higher test weight and that in the other two crosses, the differences, although favouring the white-seeded lines, were not significant (Table 6).

\section{Yellow versus Red}

On an average, the yellow and red-seeded lines did not significantly differ in percent protein, in percent oil and in 1000 kernel weight (Table 5). No significant differences in percent hull were found in 1983 but in 1984, the red-seeded lines exhibited a significantly lower percent hul1. The reduction of $1.11 \%$ represents a $3.9 \%$ improvement over the 
yellow-seeded lines. The red-seeded lines showed a significantly lower percent hul1 than the yellow-seeded lines in 11 out of the 15 pairs.

The red-seeded lines had a significantly lower, test weight $(0.74$ $\mathrm{kg} / \mathrm{hl}$ difference) compared to the yellow-seeded 1ines. Red-seeded lines in six of the 15 pairs were significantly lower whereas in one case, the red-seeded line had a significantly higher test weight.

A significant difference in germination index was found between the yellow and red-seeded lines, the former having a higher germination index but the difference was too small to represent a useful difference in resistance to pre-harvest sprouting.

\section{Yellow versus White}

No significant differences in percent hull, percent protein and percent oil were found between the yellow and white-seeded lines in 1983 . However, significant differences were obtained for the three characteristics investigated in 1984. The white-seeded lines were higher in test weight, had smaller kernels as shown by a significantly lower 1000 kernel weight and had a significantly lower percent hull than the yellow-seeded lines. A reduction of $1.70 \%$ hull of the white-seeded lines represents a $6.2 \%$ improvement over the yellow-seeded lines. (Table 5)

The white-seeded lines had a significantly higher test weight in 5 out of the 10 pairs; yellow was significantly higher in one of the pairs. The white lemma lines of nine pairs had a significantly lower percent hu11; the difference between the lines of the 10th pair was nonsignificant. 


\section{Black versus Non-black}

The results obtained for the black versus non-black lemma colour comparison indicate that the black-seeded lines had, on an average, a significantly lower test weight than the non-black-seeded lines, the difference being $2.29 \mathrm{~kg} / \mathrm{hl}$. In 1983, a significant difference of $2.12 \%$ hull was found with the black-seeded lines having a higher percent hull. The difference was not significant in 1984. No significant differences in percent protein were found in either the whole grain or the groat. However, on an average, the black-seeded lines had a significantly higher percent oil than the non-black-seeded lines. The lines did not differ in either 1000 kernel weight or the three sprouting parameters used to evaluate pre-harvest sprouting resistance. (Table 5)

\section{Discussion}

Effect of lemma colour, kernel type and environment on percent hull in oats

Results of this study suggest the existence of a significantly lower percent hull in red-seeded compared to white-seeded lines. In the cultivar trial, percent hull varied from location to location but the absence of a significant year $X$ line interaction suggest that the difference between white and red would be consistent from year to year.

Determination of percent hull using primary kernels provided the same results as the combined data in terms of differences between lines. However, it also gave information on the effect of year on percent hull. 
This would imply that in a genetic study, primary kernels should be used instead of a random sample of primary and secondary kernels in which the proportion of 1 primary: 1 secondary kernel would not always be obtained. Based on these results, samples of primary kernels were used to study the effect of lemma colour on the grain quality characteristics percent hull and percent protein in oats.

\section{Effect of lemma colour on grain quality in oats}

The agronomic data and observations in the field indicate that there was little difference between the lines making up each near-isogenic pair. However differences among pairs in plant appearance, plant height and heading date were evident permitting the genes for lemma colour to be studied in different backgrounds.

The growing conditions differed in both years of the experiment. Results for 1984 are considered more reliable because the conditions were more favourable for a good expression of the genotype than in 1983 where the smal1 plots were affected more by hot and dry growing conditions and a serious disease infection. The larger plots used in 1984 also provided more uniform and representative samples.

Low percent hull and high test weight have been cited frequently as important criteria of grain quality in oats. A reduced hull percent is particularly important because oat hulls have virtually no nutritional value for non-ruminants. They also reduce the energy content of the whole oat kerne1 and, therefore, make oats less advantageous than other grains 
for feed purposes. For human food, hu1ls must be removed and percent hull is considered the main factor that limits milling efficiency. A major breeding objective is to reduce the proportion of hulls in the oat grain without affecting negatively the other grain quality characteristics and yield.

Red lemma colour was found to be associated with low percent hull and low test weight in the white versus red and yellow versus red lemma colour comparisons. In 1984, the reduction in percent hull represented $4.4 \%$ of the mean percent hull of the white-seeded lines and $3.9 \%$ of that of the yellow-seeded lines and constitute progress toward the breeding objective of reducing the proportion of hulls in the oat grain. Unfortunaly, red lemma colour was also associated with a lower test weight in both comparisons but the overall difference of $0.73 \mathrm{~kg} / \mathrm{hl}$ might be considered less important than the reduction in percent hu11.

In comparison to yellow, white oats were of higher quality with a significantly lower percent hull in 1984 and a significantly higher test weight. However they had smaller kernels as indicated by a significantly lower 1000 kernel weight.

Results of the black versus non-black lemma colour comparison suggest that the black lemma colour was associated with a higher percent oil. This could increase the energy content of the oat grain but the difference of $0.31 \%$ is too small to consider the black-seeded lines of higher quality than the non-black-seeded lines; moreover the black-seeded lines had a significantly lower test weight and a significantly higher percent hul1 in 1983. The non-significance of the difference in percent 
hull in 1984 could be due to the smaller number of pairs that were used in that year.

The results of this study differ somewhat from what was found in the progenies of crosses between A.sativa and the species $\underline{\text { A.sterilis }}$ and A.fatua. In A.sterilis, dark lemma colours (black, grey or brown) were associated with a higher percent hull and a higher percent protein (Lyrene and Shands,1975). In A.fatua, dark lemma colours (grey, dark brown or red) were found to be associated with a higher percent hull, a lower groat oil percentage and a lower groat protein percentage (Luby and Stuthman,1983). The results of the present study indicate that, in A.sativa, red lemma colour was associated with lower percent hull and black lemma colour was associated with both high percent hull and high percent oil. None of the lemma colours appeared to be associated with the quality characteristic percent protein in 1983 where the environmental conditions may have masked a genetic difference. Therefore, it seems that different associations exist in the three avenae species.

Another point of concern is the inheritance of the associations. The two most likely hypotheses are linkage between genes responsible for the characters involved and pleiotropism i.e. the gene for lemma colour has a direct effect on the other character. The presence of recombinants (i.e. progeny showing the inverse relationship) among the near-isogenic pairs of lines would support the hypothesis of linkage. As mentioned in the results, such pairs are present. However, these lines could be the result of independent segregation for other genes conditioning the grain quality characteristics (quantitative traits). If this is the case, then pleiotropism is a plausible explanation. Lyrene and Shands(1975) 
suggested that the gene responsible for shattering, which appeared to be closely linked with dark lemma colours in A.sterilis, might have a pleiotropic effect on the characters associated with it. In the .present study this situation could have been clarified by carrying on the selection up to the $\mathrm{F}_{10}$ generation where the lines would have been more nearly isogenic differing only for the genes for lemma colour and those very closely associated with them.

In the process of selecting good quality oat lines, one would be a step ahead by selecting among red-seeded progenies in preference to other colour classes or among white-seeded progenies in preference to yellow. No associations were found between lemma colours and the agronomic characters studied. Therefore, the breeder will have freedom to select for yield, short straw and maturity within any hull colour class. 
TABLE 1. Parents used in the study of the effect of lemma colour on grain quality in oats

\begin{tabular}{lcc} 
Parent & Origin & Lemma Colour \\
\hline Portmore & Scotland & White \\
Etive & $"$ & $"$ \\
Levin & $"$ & $"$ \\
Dula & Holland & $"$ \\
Calibre & Saskatoon & $"$ \\
Lamar & Quebec & Yellow \\
OT 233 & Winnipeg & White \\
OT 224 & Winnipeg & Red \\
\hline
\end{tabular}


TABLE 2. Mean hul1 percentage of the primary kernels, secondary kernels and the combined data of four oat lines differing in hul1 colour and grown at five locations in 1982 and 1983

\begin{tabular}{llccr}
\hline & & \multicolumn{3}{c}{ KERNEL } \\
\cline { 3 - 5 } Line & Colour & Primary & Secondary & $\begin{array}{r}\text { Combined data } \\
(58: 42)(2)\end{array}$ \\
\hline DUMONT & White & $25.12 \mathrm{a}(1)$ & $18.67 \mathrm{a}$ & $22.41 \mathrm{a}$ \\
OT 233 & White & $23.97 \mathrm{~b}$ & $17.88 \mathrm{ab}$ & $21.41 \mathrm{~b}$ \\
OT 224 & Red & $23.36 \mathrm{bc}$ & $17.74 \mathrm{~b}$ & $21.01 \mathrm{bc}$ \\
OT 234 & Red & $22.89 \mathrm{c}$ & $17.31 \mathrm{~b}$ & $20.55 \mathrm{c}$ \\
\hline MEAN & & 23.84 & 17.90 & 21.34 \\
C.I. (.05) & & $23.43-24.24$ & $17.51-18.29$ & $20.97-21.72$ \\
\hline
\end{tabular}

(1)data followed by the same letter are not significantly different using the Isd test.

(2)average proportion of primary and secondary kernels on a weight basis on samples of equal number of both kernel types of the four oat lines grown at three locations. 
TABLE 3. Analyses of variance of hull percentages of four oat lines differing in hull colour and grown at five locations in 1982 and 1983

\begin{tabular}{llccc}
\hline & & \multicolumn{3}{c}{ KERNEL } \\
\cline { 3 - 5 } $\begin{array}{l}\text { Source of } \\
\text { variation }\end{array}$ & df & Mean Square & Mean Square & $\begin{array}{c}\text { Combined Data } \\
\frac{(58: 42)^{(2)}}{\text { Mean Square }}\end{array}$ \\
\hline Block(location) & 4 & $3.51^{* *(1)}$ & $6.53^{* *}$ & $4.48^{* *}$ \\
Year & 1 & $4.17^{*}$ & $0.24 \mathrm{~ns}$ & $0.96 \mathrm{~ns}$ \\
Line & 3 & $9.31^{* *}$ & $3.21 *$ & $6.32^{* *}$ \\
white X red & 1 & $20.16^{* *}$ & $5.63 *$ & $12.92^{* *}$ \\
white X white & 1 & $6.61^{* *}$ & $3.12 \mathrm{~ns}$ & $7.32 *$ \\
red X red & 1 & $1.1 \mathrm{~ns}$ & $0.92 \mathrm{~ns}$ & $1.49 \mathrm{~ns}$ \\
Year X Line & 3 & $0.24 \mathrm{~ns}$ & $0.35 \mathrm{~ns}$ & $0.20 \mathrm{~ns}$ \\
Error & 28 & 0.71 & 0.90 & 0.69 \\
\hline
\end{tabular}

(1) $\mathrm{ns}, *$ ** nonsignificant, significant at 0.05 and 0.01 leve1 of probability respectively.

(2)average proportion of primary and secondary kernels on a weight basis based on samples of equal number of both kernel types of the four oat lines grown at three locations. 
TABLE 4. Mean values of heading date, height and yield for the four lemma colour comparison experiments grown at Glenlea, Manitoba in 1984

\begin{tabular}{|c|c|c|c|}
\hline \multirow[b]{2}{*}{ Lemma colour } & \multicolumn{3}{|c|}{ AGRONOMIC CHARACTERS } \\
\hline & $\begin{array}{l}\text { Heading date } \\
\quad \text { (days) }\end{array}$ & $\begin{array}{l}\text { Height } \\
(\mathrm{cm})\end{array}$ & $\begin{array}{c}\text { Yield } \\
(\mathrm{kg} / \mathrm{ha})\end{array}$ \\
\hline White & 64.495 & 111.40 & 4912 \\
\hline Red & 64.486 & 111.83 & 4938 \\
\hline Difference & $0.009 \pm .07(1)$ & $-0.43 \pm .38$ & $-26 \pm 42$ \\
\hline $1 s d$ & ns (2) & ns & ns \\
\hline Yellow & 66.21 & 110.90 & 5174 \\
\hline Red & 66.52 & 110.14 & 5090 \\
\hline Difference & $-0.31 \pm .16$ & $0.76 \pm .63$ & $84 \pm 63$ \\
\hline $1 \mathrm{sd}$ & ns & ns & ns \\
\hline Yellow & 67.10 & 118.76 & 4943 \\
\hline White & 66.73 & 117.17 & 4993 \\
\hline Difference & $0.37 \pm .17$ & $1.59 \pm .63$ & $-50 \pm 74$ \\
\hline $1 s d$ & ns & $1.30 *$ & ns \\
\hline Black & 59.71 & 123.79 & 4614 \\
\hline Non-black & 59.29 & 126.14 & 4398 \\
\hline Difference & $0.42 \pm .28$ & $-2.35+1.76$ & $216 \pm 95$ \\
\hline $1 s d$ & ns & $\mathrm{ns}$ & ns \\
\hline
\end{tabular}

(1)mean difference and standard error of mean

(2)ns, * nonsignificant, significant at 0.05 level of probability 
TABLE 5. Effect of near-isogenic lines differing in lemma colour on grain quality characteristics of oats in 1983 and 1984

\begin{tabular}{|c|c|c|c|c|c|c|c|c|c|c|}
\hline & & & & GRAII & QUALITY $\mathrm{C}$ & ARACTERIS & & & & \\
\hline & $\% \mathrm{Hul1}$ & ${ }^{5} 6$ Protein & $\%$ Protein & $\%$ Oil & & $\begin{array}{l}\text { generati } \\
\text { erminatio }\end{array}$ & & Fos gene & 1000 kernel & $\begin{array}{l}\text { Data) } \\
\% \text { Hull }\end{array}$ \\
\hline & & (grain) & (groat) & & DMG 3 & PGS & GIS & $(\mathrm{kg} / \mathrm{hL})$ & weight(g) & \\
\hline White & 27.60 & 14.08 & 19.46 & 5.01 & 5.55 & 99.75 & 63.55 & 45.67 & 30.94 & 26.66 \\
\hline Red & 26.75 & 14.24 & 19.44 & 5.03 & 5.95 & 98.75 & 61.02 & 44.93 & 31.22 & 25.49 \\
\hline Difference & $\begin{array}{c}0.85 \pm \\
0.39\end{array}$ & $\begin{array}{c}-0.16 \pm \\
0.20\end{array}$ & $\begin{array}{c}0.02 \pm \\
0.30\end{array}$ & $\begin{array}{c}-0.02 \pm \\
0.06\end{array}$ & $\begin{array}{c}-0.40 \pm \\
0.19\end{array}$ & $\begin{array}{c}1.00 \pm \\
1.00\end{array}$ & $\begin{array}{c}2.53 \pm \\
2.30\end{array}$ & $\begin{array}{c}0.73 \pm \\
0.16\end{array}$ & $\begin{array}{c}-0.28 \pm \\
0.27\end{array}$ & $\begin{array}{c}1.17 \pm \\
0.11\end{array}$ \\
\hline lsd & $0.79 *$ & ns & ns & ns & ns & ns & ns & $0.42^{* *}$ & ns & $0.31 * *$ \\
\hline Yellow & 29.54 & 14.18 & 20.18 & 5.09 & 5.75 & 100 & 61.35 & 44.71 & 29.85 & 28.29 \\
\hline Red & 29.27 & 13.96 & 19.63 & 5.15 & 6.15 & 99 & 55.88 & 43.97 & 30.21 & 27.18 \\
\hline Difference & $\begin{array}{c}0.27 \pm \\
0.78\end{array}$ & $\begin{array}{c}0.22 \pm \\
0.31\end{array}$ & $\begin{array}{c}0.55 \pm \\
0.54\end{array}$ & $\begin{array}{c}-0.06 \pm \\
0.07\end{array}$ & $\begin{array}{c}-0.40 \pm \\
0.28\end{array}$ & $\begin{array}{c}1.00 t \\
1.00\end{array}$ & $\begin{array}{c}5.47 \pm \\
2.20\end{array}$ & $\begin{array}{c}0.74 t \\
0.26\end{array}$ & $\begin{array}{c}-0.36 \pm \\
0.25\end{array}$ & $\begin{array}{c}1.11 \pm \\
0.21\end{array}$ \\
\hline $1 \mathrm{sd}$ & ns & ns & ns & ns & ns & ns & $5.01 *$ & $0.56^{*}$ & ns & $0.63^{* *}$ \\
\hline Yellow & 29.03 & 13.53 & 19.06 & 5.54 & 5.35 & 100 & 61.69 & 43.01 & 30.97 & 27.44 \\
\hline White & 27.56 & 13.52 & 18.69 & 5.68 & 5.00 & 99.72 & 63.00 & 43.55 & 29.62 & 2574 \\
\hline Difference & $\begin{array}{c}1.47 \pm \\
1.12\end{array}$ & $\begin{array}{c}0.01 \pm \\
0.19\end{array}$ & $\begin{array}{l}0.37 \pm \\
0.55\end{array}$ & $\begin{array}{c}-0.14 \pm \\
0.17\end{array}$ & $\begin{array}{c}0.35 \pm \\
0.19\end{array}$ & $\begin{array}{c}0.28 \pm \\
0.28\end{array}$ & $\begin{array}{c}-1.31 \pm \\
0.72\end{array}$ & $\begin{array}{c}-0.54 t \\
0.23\end{array}$ & $\begin{array}{c}1.35 t \\
0.48\end{array}$ & $\begin{array}{c}1.70 \pm \\
0.18\end{array}$ \\
\hline $1 \mathrm{sd}$ & ns & ns & ns & ns & ns & $\mathrm{ns}$ & ns & $0.52^{*}$ & $1.08 *$ & $0.60 * *$ \\
\hline Black & 27.44 & 15.56 & 21.37 & 5.73 & 5.50 & 99.70 & 58.32 & 44.82 & 31.96 & 27.81 \\
\hline Non-black & 25.32 & 15.48 & 20.66 & 5.42 & 5.50 & 99.70 & 60.11 & 47.11 & 33.03 & 26.68 \\
\hline Difference & $\begin{array}{c}2.12 \pm \\
0.44\end{array}$ & $\begin{array}{c}0.08 \pm \\
0.31\end{array}$ & $\begin{array}{c}0.71 \pm \\
0.51\end{array}$ & $\begin{array}{c}0.31 \pm \\
0.09\end{array}$ & $\begin{array}{c}0 \pm \\
0.19\end{array}$ & $\begin{array}{c}0 \pm \\
0.17\end{array}$ & $\begin{array}{c}-1.79 \pm \\
1.30\end{array}$ & $\begin{array}{c}-2.29 \pm \\
0.47\end{array}$ & $\begin{array}{c}-1.07 \pm \\
0.74\end{array}$ & $\begin{array}{c}1.13 \pm \\
0.50\end{array}$ \\
\hline 1sd & $0.88^{* *}$ & $\mathrm{~ns}$ & ns & $0.25^{* *}$ & ns & ns & ns & $1.76^{* *}$ & ns & ns \\
\hline
\end{tabular}

$\S$ number of days to reach maximum germination (DMG); percent germination (PG); germination index (GI)

ns, * * nonsignificant, significant at 0.05 and 0.01 level of probability respectively 
TABLE 6. Effect of white versus red lemma colour on percent hull of primary kernels of near-isogenic oat lines derived from five different crosses in 1983 and 1984

\begin{tabular}{|c|c|c|c|c|c|}
\hline \multirow{3}{*}{$\begin{array}{l}\text { Progeny } \\
\text { No of pairs }\end{array}$} & \multicolumn{5}{|c|}{ PERCENT HULL - 1983} \\
\hline & \multicolumn{5}{|c|}{ CROSS } \\
\hline & 8 & 9 & 7 & 6 & 6 \\
\hline White & 27.92 & 29.02 & 27.38 & 26.75 & 26.15 \\
\hline Red & 25.90 & 28.00 & 28.22 & 26.40 & 24.66 \\
\hline Difference & $2.02 \pm .74 \S$ & $1.02 \pm .67$ & $-0.84 \pm 1.11$ & $0.35 \pm .84$ & $1.49 \pm .58$ \\
\hline \multirow[t]{3}{*}{$1 s d$} & $1.75 *$ & ns & ns & ns & $1.49 *$ \\
\hline & \multicolumn{5}{|c|}{ PERCENT HULL - 1984} \\
\hline & \multicolumn{5}{|c|}{ CROSS } \\
\hline Progeny & 1 & 2 & 3 & 4 & 5 \\
\hline No of pairs & 8 & 9 & 7 & 6 & 6 \\
\hline White & 26.70 & 27.38 & 26.26 & 27.23 & 25.40 \\
\hline Red & 25.30 & 26.24 & 25.31 & 25.85 & 24.49 \\
\hline Difference & $1.40 \pm .22$ & $1.14 \pm .20$ & $0.95 \pm .16$ & $1.38 \pm .13$ & $0.91 \pm .51$ \\
\hline 1sd & $0.77 * *$ & $0.67 * *$ & $0.59 \% *$ & $0.33 *$ & ns \\
\hline
\end{tabular}

ns, *, ** nonsignificant, significant at 0.05 and 0.01 level of probability respectively

$\S$ mean difference and standard error of mean 
TABLE 7. Effect of white versus red lemma colour on test weight of near-isogenic oat lines derived from five different crosses

\begin{tabular}{|c|c|c|c|c|c|}
\hline \multirow{4}{*}{$\begin{array}{l}\text { Progeny } \\
\text { No of pairs }\end{array}$} & \multicolumn{5}{|c|}{ TEST WEIGHT $(\mathrm{kg} / \mathrm{hL})-1984$} \\
\hline & \multicolumn{5}{|c|}{ CROSS } \\
\hline & 1 & 2 & 3 & 4 & 5 \\
\hline & 8 & 9 & 7 & 6 & 6 \\
\hline White & 44.42 & 45.87 & 45.99 & 45.71 & 46.64 \\
\hline Red & 43.64 & 45.14 & 44.76 & 45.33 & 46.18 \\
\hline Difference & $0.78 \pm .28$ & $0.73 \pm .11$ & $1.23 \pm .42$ & $0.38 \pm .60$ & $0.46 \pm .41$ \\
\hline $1 \mathrm{sd}$ & $0.66 \%$ & $0.25 *$ & $1.03 *$ & ns & ns \\
\hline
\end{tabular}




\section{REFERENCES}

ATKINS, I.M. and MANGELSDORF, P.C. 1942. Selection of isogenic lines as a means of measuring the effects of awns and other characters in sma11 grains. J. Amer. Soc. Agron. 34:667-668.

CAMPBELL, A.R. and FREY, K.J. 1972. Association between groat protein percentage and certain plant and seed traits in interspecific oat crosses. Euphytica 21:352-362.

CULBERTSON, J.0. and KOMMEDAHL, T. 1956. The effect of seed coat color upon agronomic and chemical characters and seed injury in flax. Agron. J. $\underline{48}: 25-28$.

GORDON, I.L. 1979. Selection against sprouting damage in wheat. III. Dormancy, germinative alpha-amylase, grain rednesss and flavanols. Aust. J. Agric. Res. 30:387-404.

HAGEMANN, M.G. and CIHA, A.J. 1984. Evaluation of methods used in testing winter wheat susceptibility to preharvest sprouting. Crop Sci. $24: 249-254$.

JONSSON, R. 1977. Breeding for improved oil and meal quality in rape (Brassica napus L.) and turnip rape (B. campestris L.). Hereditas 87:205-218.

LEISLE, D., KOSMOLAK, F.G. and KOVACS, M. 1981. Association of glume color with gluten strength and gliadin proteins in durum wheat. Can. J. Plant Sci. 61:149-151.

LEROY, A.S., ALBRECHTSEN, R.S. and RUMBAUGH, M.D. 1974. Relationship of . protein percent with other phenotypic characters in interspecific oat crosses. Crop Sci. 14:767-769.

LUBY, J.J. and STUTHMAN, D.D. 1983. Evaluation of Avena sativa L./ A. fatua L. progenies for agronomic and grain quality characters. Crop Sci. 23:1047-1052.

LYRENE, P.M. and SHANDS, H.L. 1975. Associations among traits in progenies from Avena sativa L. X A. sterilis L. crosses. Crop Sci. $\underline{15}: 361-363$.

ROBERTSON, J.A. and MORRISON, W.H. 1980. Analysis of oil content of sunflower seed by wide-line NMR. J. Amer. Oil Chem. Soc. 56:961-964. 
THE INHERITANCE OF LEMMA COLOUR IN OATS, AVENA SATIVA L.

\author{
A. Plourde, R.I.H. McKenzie and P.D. Brown \\ Agriculture Canada Research Station, 195 Dafoe Road, \\ Winnipeg, Manitoba, Canada R3T 2M9
}

Will be Submitted to the Canadian Journal of Genetics and Cytology 
ON THE INHERITANCE OF LEMMA COLOUR IN OATS, AVENA SATIVA L.

\begin{abstract}
The inheritance of lemma colour was studied in crosses involving seven cultivars or lines of Avena sativa L.. Red lemma colour was controlled by one dominant gene in OT 224 and OT 218. White lemma colour of the cultivars Fidler and Rodney 0 was found to be conditioned by a dominant gene. Yellow lemma colour of the cultivars Lamar and Ogle appeared to be the expression of the homozygous recessive condition of the genes at the loci controlling red and white lemma colours. The black-seeded cultivar Caravelle was found to carry a dominant gene for black epistatic to the other colour classes and a dominant gene for white. The presence of a gene for grey lemma colour in the genotype of Caravelle was expressed in one environment but not in a second and therefore could not be stated with certainty. Problems in classifying lemma colour and needs for uniform conditions to study the inheritance of lemma colour are discussed in this paper.
\end{abstract}

\title{
Introduction
}

Five lemma colour classes have been recognized in oats: black (including dark brown), grey, red, yellow and white (Stanton, 1961). Numerous investigations have provided genetic evidence for the existence 
of factors controlling the expression of lemma colour (Jensen, 1961). In spite of these extensive studies on the inheritance of this character, its genetics is still not completely understood. A total of fourteen genes influencing lemma colour has been reported in the literature (Simons et al,1978; Wong,1981). The existence of modifying and intensifying factors was also reported (Jensen,1961).

The present study was undertaken to obtain information on the genetic constitution of some oat cultivars and lines and the inheritance of lemma colour in oats.

\section{Material and Methods}

Six crosses were made in growth cabinets in the fa11 of 1982 and winter of 1983. Fidler, a white-seeded variety, and OT 224, a red-seeded oat line developed at Winnipeg, were used as the female parents in crosses with Caravelle (black), OT 218 (dark red) and Lamar (yellow). A11 the $F_{1}$ plants and portions of the $F_{2}$ populations of these crosses were grown in growth cabinets. The remaining $\mathrm{F}_{2}$ 's were grown in greenhouses. $F_{1}$ seeds of the crosses Fidler X OT 224, Rodney 0 (white) X OT 224 and Ogle (yellow) X OT 224 were made available by Dr. R.I.H. McKenzie and included in this study. The $\mathrm{F}_{1}$ plants were grown in growth cabinets and the $\mathrm{F}_{2}$ 's grown in the field at Glenlea, Manitoba in the summer of 1983 .

Since the lemma is derived from maternal tissue, classification of the segregates was made on seeds of the $F_{2}$ plants. Data of the different families of each cross were pooled when a test of homogeneity showed no differences between the families. 
The $\mathrm{F}_{3}$ generation of the crosses involving the black-seeded variety Caravelle was grown in the field at Glenlea, Manitoba in the summer of 1984 to verify the results obtained in the $F_{2}$ generation.

The Chi-square goodness of fit method was used to obtain the probability value to test the validity of the ratios obtained.

Seeds of the $F_{2}$ progenies of crosses involving a yellowseeded variety were studied under ultra-violet (U.V) light to identify the yellow-seeded progenies. West(1953) reported that seeds with yellow lemmas showed no Iuminescence i.e. they appeared dark under U.V. 1ight whereas seeds with white, pink or ivory and grey lemmas fluoresced a pale blue colour. However, this reaction does not seem to be due to a specific property of the pigment(s) responsible for the yellow lemma colour since, in the present study, fluorescent yellow seeds were found in the progeny populations. Therefore, the use of U.V. light may be useful in classifying for lemma colour but one should not rely entirely on it.

\section{Results and Discussion}

Results of the lemma colour classification of the $F_{2}$ populations of the crosses are presented in Table 1. In all of the crosses involving white-seeded and red-seeded oat varieties, the segregation of the $F_{2}$ population gave a good fit to a $3: 1$ ratio showing that the parents differed by one gene for lemma colour. The red lemma colour of OT 224 and OT 218 appeared to be controlled by a single dominant gene.

The observed segregation ratio obtained for the cross Fidler $\mathrm{X}$ Lamar fitted a 3 white: 1 yellow ratio. This suggests that the white-seeded 
parent carried a dominant gene for white. Yellow lemma colour appeared to be conditioned by the homozygous recessive condition of the gene responsible for white. The existence of dominant genes for white lemma colour has been first suggested by Welsh(1931) who crossed yellow and white oat varieties and obtained, for one of the crosses, a phenotypic ratio suggesting that two dominant genes for white were involved.

The results of the red X yellow crosses OT $224 \mathrm{X}$ Lamar and OT $224 \mathrm{X}$ Ogle, confirm the presence of a dominant gene for white in the genotype of the red parent in addition to the dominant gene for red since the data fitted a dihybrid ratio of 12 red:3 white: 1 yellow. The yellow lemma colour of Lamar and Ogle would be conditioned by the genes for red and white in their homozygous recessive condition.

Proposed genotypes of the parents of these seven crosses could be listed as follows:

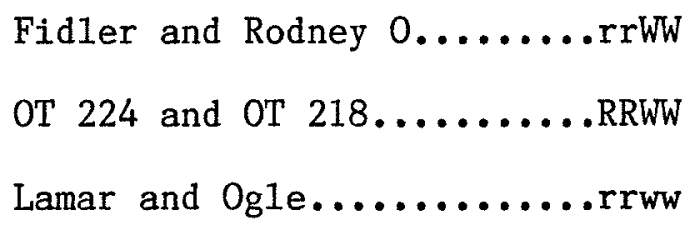

where $R$ and $W$ represent two independent dominant genes determining red and white lemma colour respectively with $R$ epistatic over $W$.

The results for the white $X$ black cross suggest that the varieties Fidler and Caravelle differed for one gene only as shown by the good fit to a 3 black: 1 white ratio. The black parent would carry a dominant gene for black(B) epistatic over the dominant gene for white known to be present in the genotype of Fidler. The results obtained for the $\mathrm{F}_{3}$ 
generation of this cross support the the hypothesis of one gene difference (Table 2).

The $F_{2}$ data of the red $X$ black cross fitted a dihybrid ratio. of 12 black:3 grey:1 red except the family 129-1. The results indicate that the black parent would carry, in addition to the dominant gene for black(B), a dominant gene for grey epistatic to the gene for red present in OT 224 . However, no grey segregates were present in the $F_{2}$ population of the cross Fidler $X$ Caravelle. The $F_{3}$ generation of the cross oT $224 X$ Caravelle was grown in the field to confirm the presence of this gene but no grey segregates were found. The data obtained for the four families are summarized in Table 2. The families could be classified into seven subclasses i.e. homozygous black, homozygous red, homozygous white and four classes representing the four possible type of colour segregation. Families 129-1 and 129-2 gave a reasonable fit to the proposed segregation ratio assuming a two gene difference. The other two families gave a good fit when subclasses were grouped together. The number of plants per $F_{2}$ progeny was too small to insure a good chance to have segregates of each colour. Difficulties in distinguishing red and white. lemma colour also contributed to the poor fit to the ratios. Robb(1932) commented on the difficulties of making accurate identification of all the possible colour groups because of the occurrence of a range of colour variation. He gave two reasons to explain the colour gradation. First, environmental conditions which result in weathering influence and sometimes even obscure the expression of lemma colour. Secondly, incomplete epistasis or the existence of modifying and intensifying genes may also contribute to the colour variation. From the results obtained, the presence of a gene for grey lemma colour in the genotype of Caravelle 
cannot be stated with certainty. The proposed genotype would be rrWWBB where $B$ is a dominant gene for black lemma colour epistatic to $W$ and $R$.

The results of this study brings out once again the common difficulties encounted by the investigators of the inheritance of lemma colour. Lemma colour is obviously very much affected by environmental conditions. The importance of conducting an inheritance study of this character under the most stable environmental conditions that we can get must be stressed. Carrying out such investigation under field condition most often leads to problems in identifying each colour class. Part of the material of this study was grown in growth cabinets and greenhouses, both environments that could provide stable conditions of temperature and moisture. A study to determine the specific conditions required for the fu11 expression of each lemma colour would help in learning more about the inheritance of this character. The $F_{2}$ and subsequent generations could, therefore, be grown under similar conditions and thus provide more precise information. 
TABLE 1. Segregation of $F_{2}$ plant population from crosses between Avena sativa varieties of different lemma colours

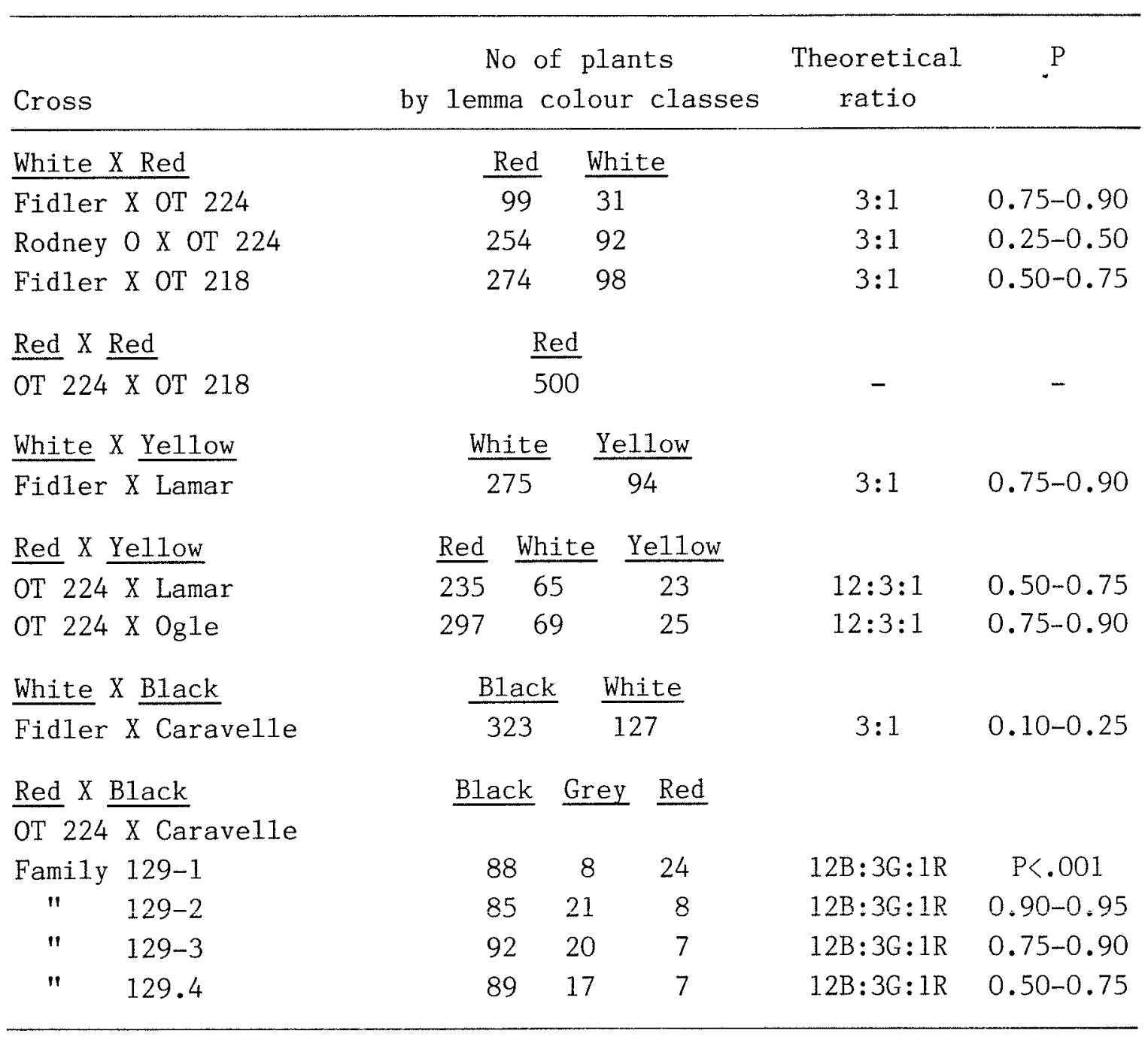


TABLE 2. Segregation for lemma colour in the $F_{3}$ families of Fidler X Caravelle and OT $224 \mathrm{X}$ Caravelle

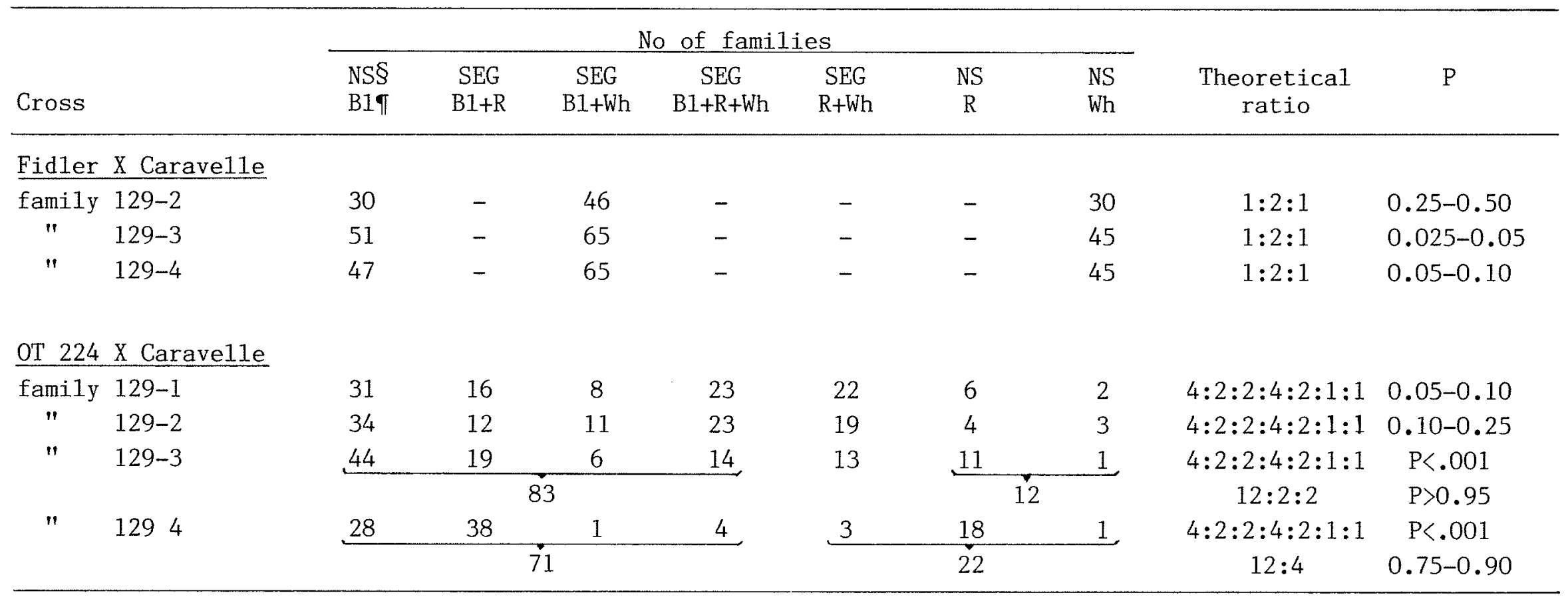

$\S$ NS, SEG nonsegregating and segregating for lemma colour

I black (B1); red (R); white (Wh) oat lemma colours 


\section{REFERENCES}

JENSEN, N.F. 1961. Genetics and inheritance in oats. In "Oats and Oat Improvement". (Coffman, F.A., ed.). Amer. Soc. Agron., Madison, Wisconsin. pp.125-206

ROBB, W. 1932. Notes on the inheritance of grain colour in certain oat hybrids. J. Genetics. 26:231-238.

SIMONS, M.D., MARTENS, J.W., McKENZIE, R.I.H., NISHIYAMA, I., SADANAGA, K., SEBESTA, J. and THOMAS, H. 1978. Oats: a standardized system of nomenclature for genes and chromosomes and catalogue of genes governing characters. U.S. Dept. Agr. Handb. No 509, 40pp.

STANTON, T.R. 1961. Classification of Avena. In "Oats and Oat Improvement". (Coffman, F.A., ed.). Amer. Soc. Agron., Madison, Wisconsin. pp.75-111.

WELSH, J.N. 1931. Inheritance of stem rust and smut reaction and lemma color in oats. Sci. Agr. 12:209-242.

WEST, D.M. 1953. Luminescence test in oat varieties. Proc. Assoc. Off. Seed Anal. 43:115-116.

WONG, L.S.L. 1981. The inheritance of resistance to Puccinia coronata avenae and of floret characters in Avena sterilis. M.Sc. Thesis. University of Manitoba, Winnipeg, Manitoba. 
GENERAL DISCUSSION

The existence of associations between an easily identifiable character and a less-visible, desirable trait has significant implications in a breeding program. It would allow the breeder to select more easily the desirable genotypes by providing a means for preliminary screening of the progeny populations. The associations must be strong i.e. due to a very close linkage or to pleiotropism so that the breeder can proceed with considerable assurance.

Associations between lemma colour and grain quality characteristics were found in the present study. The results indicated that red-seeded lines were of better quality than the white and yellow-seeded lines, that white lemma colour should be prefered to yellow lemma colour and that black lemma colour seems to be associated with an overall lower grain quality in comparison to other lemma colour classes.

The results differ somewhat with what was found in the progenies of crosses between A.sativa and the species A.sterilis and A.fatua. In A.sativa X $\underline{\text { A.sterilis }}$ progeny, numerous reports have indicated that dark seed colours (black, grey, dark brown or red) were associated with the undesirable spikelet characters (all A. sterilis traits) spikelet articulation (Middleton,1938; Lyrene and Shands,1975), presence of awns (Smith, see Jensen,1961; Kiehn et al,1976; Wong,1981) and lemma pubescence (Middleton,1938; Wong,1981). Associations between dark lemma colours (black, grey, dark brown) and high percent hull and high percent protein 


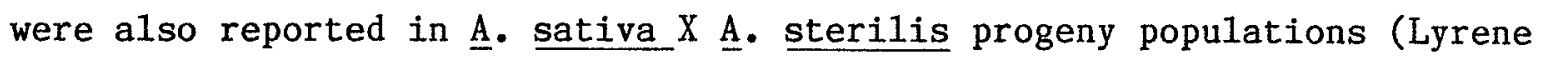
and Shands, 1975). In these progenies, white-seeded lines tended to be low in percent hull and low in protein. LeRoy et al(1974) studied the relationships among factors involved in the improvement of oat quality using A. sterilis and suggested that dark lemma colour would possibly be the only visible trait sufficiently closely associated with high percent protein to offer a simple means of selection for this quality characteristics among the progeny of $\underline{A}$. sativa X A. sterilis crosses.

Associations of seed colour and disarticulation with grain quality characteristics were also found in A. sativa X A. fatua progeny. Progeny lines with dark seed colour (black, grey, brown or red) were higher in percent hull, lower in groat protein percentage and lower in groat oil percentage (Luby and Stuthman, 1983).

In the present study, results indicated that in A.sativa, low percent hull was associated with red lemma colour in the white versus red and yellow versus red comparisons. White lemma colour was associated with lower percent hull in comparison to yellow. Black lemma colour was also associated with higher percent hull in A.sativa. No associations were found between lemma colour and the grain quality characteristic percent protein. This differs with what was found in A.sterilis and A.fatua. However, the effect of lemma colour on percent protein was investigated in grain grown in 1983 where the environment conditions may have masked a genetic difference.

No trace of dormancy was found in the material of the four lemma colour comparison experiments. A significant difference in germination 
index was found between the yellow and red-seeded lines but the difference was too small to represent a useful difference in resistance to pre-harvest sprouting. All the lines reached maximum germination (mean values approaching 100\%) within seven days. The slight difference in germination index indicates that the yellow-seeded lines germinated at a slight1y faster rate than the red-seeded lines.

The nature of the associations found in this study is not clear. The two most likely hypotheses are linkage between the genes responsible for the characters involved and pleiotropism i.e. the gene for lemma colour has a direct effect on the other character. The presence of pairs showing the inverse relationship among the near-isogenic pairs of lines would support the hypothesis of linkage.

For the grain quality characteristic percent hull, one pair out of the 36 pairs of white versus red oats tested in 1984 gave a significant negative difference $(-1.54 \%$ hull) $i . e$. the red-seeded line had a significant higher percent hull. Several hypotheses could be proposed to explain the presence of this aberrant pair. A linkage between the genes for red lemma colour and the gene(s) for low percent hull associated with it would produce four types of progenies. The parental types i.e. red-seeded lines with low percent hull and white-seeded lines with a high percent hull would occur in a high frequency in the progeny population. The recombinants i.e. red-seeded lines with a high percent hull and white-seeded lines with a low percent hull would occur in a lower frequency. The magnitude of the frequencies depends upon the linkage intensity. In any of the near-isogenic pairs, the odds of picking up any combination of two types among the progeny are a function of their rela- 
tive proportion in the population. The probabilities of getting a pair composed of the two parental types are higher than the probabilities of getting a pair with one parental type and one recombinant i.e. the two possible pairs, red-seeded low percent hull with white-seeded low percent hull and red-seeded high percent hull with white-seeded high percent hul1. Such pairs would give a non-significant difference in percent hull. The odds are even less of picking up the two recombinant types i.e. red-seeded high percent hull oat line with a white-seeded low percent hull oat line. The occurrence of only one pair showing a significant inverse relationship i.e. the two recombinant types, among the 36 pairs, suggests that the Iinkage is quite strong. None of the pairs in the yellow versus red and yellow versus white experiments showed the inverse significant relationship although pairs exhibiting a non-significant difference were present.

However, the possibility exists that the aberrant pair for percent hull found in the white versus red experiment might be the result of independent segregation for the other genes conditioning low percent hull because they are not true isogenic lines. Percent hull is probably polygenically inherited. Wesenberg and Shands(1973) suggested that several genetic factors influence caryopsis percentage (hul1 percentage is inversely related to caryopsis percentage) and that the effects are additive. The magnitude of the overall significant differences in percent hull obtained in the present study suggests that the genes for lemma colour are probably linked with one gene controlling low percent hull. It is possible that the near-isogenic lines differed for more than one gene and that the aberrant pairs resulted from independent segregation of 
these genes. The number of genes involved depends upon the level of near-isogeny reached in developing the lines up to the $F_{6}$ generation. By carrying on the selection of the near-isogenic lines up to the. $\mathrm{F}_{10}$ or further generations so as the lines would have been more nearly isogenic differing only for the genes for lemma colour and those very closely linked with them, one would have minimized the chances of independent segregation of genes. Under such conditions, the hypothesis of pleiotropism would be plausible in the absence of crossovers. Lyrene and Shands(1975) suggested that the gene responsible for shattering, which appeared to be closely linked with dark lemma colours in A.sterilis, might have a pleiotropic effect on the characters associated with it.

Thirdly, the aberrant pair for percent hull found in the white versus red experiment could also be the result of differences in environmental effect. Although the lines of each pair were selected so as they have the same disease reaction, it is possible that this pair was not isogenic for this character. The red-seeded line could have been susceptible to disease whereas the white-seeded line was resistant. The results would be that the red-seeded line was more affected by the environment resulting in an apparent difference in percent hull favouring the white-seeded line.

The last hypothesis is that an unfortunate admixture occurred sometime during the process of selecting the near-isogenic lines possibly when the $\mathrm{F}_{6}$ generation was grown. Seeds of this plant were used for increase purposes and sown in New Zealand. If an admixture occurred, the lines would not be near-isogenic and would give a random response depending on the genotypes of the two lines composing the non isogenic 
pair.

For the grain quality characteristic test weight, a larger number of pairs showing the significant inverse relationship were found in the white versus red ( 3 pairs), yellow versus red ( 1 pairs) and yellow versus white ( 1 pair) experiments. This may suggest that the gene for lemma colour and the gene(s) for test weight are more loosely linked. It would, therefore, be easier to break the association red lemma colour-low test weight than the association white lemma colour-high percent hull found in the white versus red experiment.

That the associations are due to close linkage or pleiotropism is not important in itself. What is of interest is that red lemma oats have a slight advantage over the other colour classes in terms of percent hul1 and the association seems to be quite strong. To get red oats with the lowest percent hull possible, we would have to find the red oat lines having the best combination of genes for low percent hull. The 1inkage between the red lemma colour gene and low test weight appeared to be more loose. This gives the breeder the possibility of selecting red-seeded lines with a low percent hull and a high test weight.

The usefulness of these associations depends also on how easy it would be to work with the seed character lemma colour. Lemma colour is a qualitative trait although its genetics is fairly complex and not completely understood yet. This character appears to be conditioned by a multiple series of colour genes (Jensen,1961). This series proceeds from black through brown, red, grey, yellow and white. Fourteen genes influencing lemma colour have been reported in the literature (Simons et 
a1,1978; Wong,1981) and there could be many more. The presence of modifying or inhibitory factors brings further complications in the inheritance pattern.

However, as shown by the results of the present study on the inheritance of lemma colour in oats, this character is sometimes influenced by environmental conditions (grey is probably the most sensitive) which may obscure or alter the expression of a gene so that the colour does not develop properly. This makes accurate identification of colour classes difficult to do and therefore hinders the efforts to study the inheritance of this character. This also makes this character harder to work with than might be expected with single qualitative genes. Nevertheless gross differentiation between the five lemma colour classes is possible so the breeder should be able to use lemma colour as an index to select for good quality oats.

Two genes for each of the red, yellow and white lemma colours have been reported. Which of these genes were involved in the present study is a question to which no answer is available. In this study we probably have only one gene for red (from OT 224), one gene for yellow (from Lamar) and maybe one dominant gene for white (from the white-seeded parents). If this is the case, the question arises whether the other genes for lemma colour would also be associated with grain quality characteristics. Only a lot more work could answer this question.

No technical help or tool is available to assist the investigator in his colour classification but the use of U.V. 1ight. However, as a side part of this study (unpublished data), a biochemical analys is of the pig- 
ments was undertaken to characterize the colour classes and possibly identify the pigments involved. The ultimate goal would be to develop a quick chemical assay for colour classification purposes. Such techniques could also be useful in a study of the effect of environmental conditions on pigment synthesis and colour development in the lemma. The work was embryonic but the results suggested differences between colours and opened a promising area of study. 


\section{LIST OF REFERENCES}

AAMODT, O.S., JOHNSON, L.P.V. and MANSON, J.M. 1934. Natura1 and artificial hybridization of Avena sativa with A.fatua and its relation to the origin of fatuoids. Can. J. Res.11:701-727.

ATKINS, I.M. and MANGELSDORF, P.C. 1942. Isolation of isogenic lines as a means of measuring the effects of awns and other characters in small grains. J. Amer. Soc. Agron. 34:667-668.

BAKER, R.J. and McKENZIE, R.I.H. 1972. Heritability of oil content in oats, Avena sativa L.. Crop Sci. 12:201-202.

BERRY, R.A. 1920. Composition and properties of oat grain and straw. J. Agric. Sci. $\underline{X}(\mathrm{IV}): 359-414$.

BRIGGLE, R.T., SMITH, R.T., POMERANZ, Y., and ROBBINS, G.S. 1975. Protein concentration and amino acid composition of Avena sterilis L. groats. Crop Sci. 15:547-549.

BROWN, C.M., and CRADDOCK, J.C. 1972. Oil content and groat weight of entries in the world oat collection. Crop Sci. 12:514-515.

BROWN, C.M., WEBER, E.J., and WILSON, C.M. 1970. Lipid and amino acid composition of developing oats (Avena sativa L. cultivar Brave). Crop Sci. 10:488-490.

BONNETT, 0.T. 1961. Morphology and development. In "Oats and Oat Improvement." (Coffman,F.A., ed.) Amer. Soc. Agron., Madison, Wisconsin, pp.41-74.

CAMPBELL, A.R., and FREY, K.J. 1972. Association between groat protein percentage and certain plant and seed traits in interspecific oat crosses. Euphytica 21:352-362.

CANADIAN GRAIN COMMISSION. Official grain grading guide, 1984 edition, Canadian grain commission, Inspection division, Winnipeg, Manitoba, 1984, pp 33-39.

COFFMAN, F.A. 1964. Inheritance of morphologic characters in Avena. U.S. Dept. of Agr. Tech. Bu1. No 1308.pp.2-25.

COFFMAN, F.A., and FREY, K.J. 1961. Influence of climate and physiologic factors on growth in oats. In "Oats and Oat Improvement". (Coffman,F.A., ed.) Amer. Soc. Agron., Madison, Wisc.,pp.420-464.

COFFMAN, F.A. and STANTON, T.R. 1938. Variability in germination of fresh1y harvested Avena. J. Agr. Res. 30:1063-1082. 
COFFMAN, F.A., STANTON, T.R., BAYLES, B.B., WIEBE, G.A., SMITH, R.W., and TAPKE,V.F. 1931. Inheritance of resistance in oats to Ustilago levis. J. Agr. Res. 43:1085-1099.

CULBERTSON, J.0. and KOMMEDAHL, T. 1956. The effect of seed coat color upon agronomic and chemical characters and seed injury in flax. Agron. J. 48:25-28.

FAO. 1983. 1982 FAO production yearbook. FAO statistics series No $47: 108-119$

FLORELL, V.H. 1931. Inheritance of type of floret separation and other characters in interspecific crosses in oats. J. Agr. Res. 43:365-386.

FORSBERG, R.A. and NISHTYAMA, I. 1969. Instability for crown rust reaction and kernel color in $F_{6}-F_{10}$ lines of a derived-tetraploid $X$ Avena sativa hybrid. Crop Sci. 9: $723-725$.

FORSBERG, R.A., YOUNGS, V.L. and SHANDS, H.L. 1974. Correlations among chemical and agronomic characteristics in certain oat cultivars and selections. Crop Sci. 14:221-224.

FREY, K.J. 1973. Improvement of the quantity and quality of cereal grain protein. In "Alternate sources of protein for animal production. Nat. Acad. Sci., Washington, D.C., pp.9-41.

FREY, K.J. 1977. Proteins of oats. Z.Pflanzenzuchtg. 78:185-215.

FREY, K.J., and HAMMOND, E.G. 1975. Genetics, characteristics and utilization of oil in caryopses of oat species. J. Am. Oil Chem. Soc. 52:358-362.

GARBER, R.J., GIBBINGS, N.J. and HOOVER, M.M. 1929. Transgressive segregation for susceptibility to smut in an oat cross. J. Agr. Res. 39:953-962.

GORDON, I.L. 1979. Selection against sprouting damage in wheat. III. Dormancy, germinative alpha-amylase, grain redness and flavanols. Aust. J. Agric. Res. 30:387-404.

HAGEMAN, M.G. and CIHA, A.J. 1984. Evaluation of methods used in testing winter wheat susceptibility to preharvest sprouting. Crop Sci. 24:249-254.

HARLAN, H.V. 1914. Some distinction in our cultivated barleys with reference to their use in plant breeding. U.S. Dept. Agr. Bull. No 137.38pp.

HAYES, H.K., GRIFFEE, F., STEVENSON, F.J. and LUNDEN, A.P. 1928. Correlated studies in oats of the inheritance of reaction to stem rust and smuts and of other differential characters. J. Agr. Res. 36:437-457.

HUNTER, E. 1924. Oats: Their varieties and characteristics. Ernest Benn 
Ltd., London, 421p.

JENSEN, N.F. 1961. Genetics and inheritance in oats. In "Oats and Oat Improvement". (Coffman,F.A., ed.) Amer. Soc. Agron., Madison, Wisconsin, pp.125-206.

JOHNSON, L.P.V. 1933. Studies on the inheritance of covered smut reaction, lemma color, awn development and rachilla pubescence in oats. Can. J. Res. 9: 519-541.

JONSSON, R. 1977. Breeding for improved oil and meal quality in rape (Brassica napus L.) and turnip rape (B. campestris L.) Hereditas 87:205-218.

KENT, N.L. 1975. Technology of cereals with special reference to wheat. 2nd ed. Pergamon Press, 0xford. pp.26-42.

KEY, M. 1959. Genetics of some agronomic characters of oats. In "Breeding of grain species". Kappert, H. and W. Rudorf.(eds.) p.505-512.

KIEHN, F.A., McKENZIE, R.I.H. and HARDER, D.E. 1976. Inheritance of resistance to Puccinia coronata avenae and its association with seed characteristics in four accessions of Avena sterilis. Can. J. Genet. Cytol. 18:717-726.

KO, S.Y., TORRIE, S.H. and DICKSON, J.G. 1946. Inheritance of reaction to crown rust and stem rust and other characters in crosses between Bond,

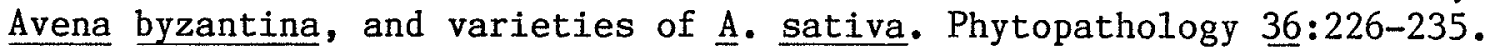

LEISLE, D., KOSMOLAK, F.G. and KOVACS, M. 1981. Association of glume color with gluten strength and gliadin proteins in durum wheat. Can. J. Plant Sci. 61:149-151.

LeROY, A.S., ALBRECHTSEN, R.S. and RUMBAUGH, M.D. 1974. Relationship of protein percent with other phenotypic characters in interspecific oat crosses. Crop Sci. 14:767-769.

LOVE, H.H. and CRAIG, W.T. 1918a. The relation between color and other characters in certain Avena crosses. Am. Naturalist 52:369-383.

LOVE, H.H. and CRAIG, W.T. 1918b. Small grain investigations. J. Heredity 9:67-76.

LOVE, H.H. and CRAIG, W.T. 1929. A note on yellow fatuoids. J. Heredity 20: 172 .

LOVE, H.H. and FRASER, A.C. 1917. The inheritance of the weak awn in certain Avena crosses. Am. Naturalist 51:481-493.

LUBY, J.J. and STUTHMAN, D.D. 1983. Evaluation of Avena sativa L./ A. fatua L. progenies for agronomic and grain quality characters. Crop Sci. 23:1047-1052. 
LYRENE, P.M. and SHANDS, H.L. 1975. Associations among traits in progenies from Avena sativa L. X A.sterilis L. crosses. Crop Sci.15:361-363.

McEWAN, J.M. 1975. Relative sprouting resistance of closely-related wheats differing in grain colour. Cer. Res. Comm. 4:151-155.

MCKENZIE, R.I.H. and FLEISCHMANN, G. 1964. The inheritance of crown rust resistance in selections from two Israeli collections of Avena sterilis. Can. J. Genet. Cyto1. 6:232-236.

McKENZIE, R.H.I., MARTENS, J.W., FLEISCHMANN, G. and SAMBORSKI, D.J. 1968. An association of stem rust and crown rust resistance in Jostrain oats. Can. J. Genet. Cyto1. 10:190-195.

MIDDLETON, G.K. 1938. Inheritance in a cross between Avena sativa and A.sterilis Ludoviciana. J. Am. Soc. Agron. 30:193-208.

MULLICK, D.B., FARIS, D.G., BRINK, V.C. and ACHESON, R.M. 1958. Anthocyanins and anthocyanidins of the barley pericarp and aleurone tissues. Can. J. Plant Sci. 38:445-456.

PERCIVAL, J. 1921. The wheat plant. London Duckworth and co. Ed. London, England.pp.7-23.

PETERSON, D.M. 1976. Protein concentration, concentration of protein fractions, and amino acid balance in oats. Crop Sci. 16:663-666.

PHILP, J. 1933. The genetics and cytology of some interspecific hybrids of Avena. J. Genet. 27:133-179.

REED, G.M. 1931. Inheritance of smut resistance in hybrids of Early Gothland and Monarch oats. Am. J. Bot. 18:803-815.

REED, G.M. and STANTON, T.R. 1925. Relative susceptibility of selections from a Fulghum-Swedish Select cross to the smuts of oats. J. Agr. Res. 30: 375-391.

RIEGER, R., MICHAELIS, A. and GREEN, M.M. 1976. Glossary of genetics and cytologenetics: Classified and Molecular. 4th ed. Springer-Verlag, Berlin Heidelberg, New-York, 647 pp.

ROBB, W. 1932. Notes on the inheritance of grain colour in certain oat hybrids. J. Genetics 26:231-238.

ROBBINS, G.S., POMERANZ, Y. and BRIGGLE, L.W. 1971. Amino acid composition of oat groats. J. Agric. Food Chem. 19:536-539.

ROBERTSON, J.A. and MORRISON, W.H. 1980. Analysis of oil content of sunflower seed by wide-1ine NMR. J. Amer. Oil Chem. Soc. 56:961-964.

SAMPSON, D.R. 1971. Additive and nonadditive genetic variances and genetypic correlations for yield and other traits in oats. Can. J. Genet. 
Cytol. 13:864-872.

SIMONS, M.D., MARTENS, J.W., McKENZIE, R.I.H., NISHIYAMA, I., SADANAGA, K., SEBESTA, J. and THOMAS, H. 1978. Oats: A standardized system of nomenclature for genes and chromosomes and catalogue of genes governing characters. U.S. Dept. Agr. Handb. No 509, 40 pp.

STANTON, T.R. 1961. Classification of Avena. In "Oats and Oat

Improvement". (Coffman,F.A., ed.) Amer.Soc. Agron., Madison, Wisconsin. pp.75-111.

STATISTICS CANADA. 1984. Field crop reporting series. 63(7), 12 pp.

STUTHMAN, D.D. and GRANGER, R.M. 1977. Selection for caryopsis percentage in oats. Crop Sci. 17:411-414.

SURFACE, F.M. 1916. Studies on oat breeding. III. On the inheritance of certain glume characters in the cross Avena fatua X A.sativa var. Kherson. Genetics 1:252-286.

TORRIE, J.H. 1939. Correlated inheritance in oats of reaction to smuts, crown rust, stem rust, and other characters. J. Agr. Res. 59:783-804.

U.S. DEPARTMENT OF AGRICULTURE. 1967. Oats: most protein per acre? Agr. Res. 16:8-9.

WAKABAYASHI, S. 1921. A study of hybrid oats, Avena sterilis X Avena orientalis. J. Am. Soc. Agron. 13:259-266.

WELSH, J.N. 1931. Inheritance of stem rust and smut reaction and lemma color in oats. Sci. Agr. 12:209-242.

WELCH, R.W. 1975. Fatty acid composition of grain from winter and spring sown oats, barley and wheat. J. Sci. Fd. Agric. 26:429-435.

WESENBERG, D.M. and SHANDS, H.L. 1971. Caryopsis percentage and related characters in early generations of Avena sativa L.. Crop Sci. 11:586-588.

WESENBERG, D.M. and SHANDS, H.L. 1973. Heritability of oat caryopsis percentage and other grain quality components. Crop Sci. 13:481-484.

WILSON, J.H. 1904. Variation in oat hybrids. Nature $\underline{69: 413 .}$

WONG, L.S.L. 1981. The inheritance of resistance to Puccinia coronata avenae and of floret characters in Avena sterilis. M.Sc. thesis. University of Manitoba, Winnipeg, Manitoba. 
APPENDIX 1. Mean values for the agronomic and grain quality characteristics of the white versus red near-isogenic pairs of lines grown at Glenlea, Manitoba in 1983 and 1984

\begin{tabular}{|c|c|c|c|c|c|c|c|c|c|}
\hline \multirow[b]{3}{*}{ Pair } & \multirow[b]{3}{*}{$\begin{array}{l}\text { Leinma } \\
\text { Colour }\end{array}$} & \multicolumn{3}{|c|}{ Agronomic Characters } & \multicolumn{5}{|c|}{ Grain Oulality Characteristics } \\
\hline & & \multicolumn{3}{|c|}{1984} & \multicolumn{3}{|c|}{1984} & \multicolumn{2}{|c|}{1983} \\
\hline & & $\begin{array}{l}\text { Height } \\
\text { (cin) }\end{array}$ & $\begin{array}{l}\text { Heading } \\
\text { date } \\
\text { (days) }\end{array}$ & $\begin{array}{c}\text { Yield } \\
(\mathrm{kg} / \mathrm{ha})\end{array}$ & $\begin{array}{l}\text { Test wt } \\
(\mathrm{kg} / \mathrm{h} 1)\end{array}$ & $\begin{array}{l}1000 \text { kerne1 } \\
\text { wt }(\mathrm{g})\end{array}$ & $\begin{array}{c}\text { Hul1 } \\
\%\end{array}$ & $\begin{array}{c}\mathrm{H} u 11 \\
\%\end{array}$ & $\begin{array}{c}\mathrm{Oi1} \\
\%\end{array}$ \\
\hline 2 & $\begin{array}{l}\text { WT } \\
\mathrm{R}\end{array}$ & $\begin{array}{l}108.50 \\
110.00\end{array}$ & $\begin{array}{l}66.00 \\
65.50\end{array}$ & $\begin{array}{l}4280 \\
5135\end{array}$ & $\begin{array}{l}43.50 \\
42.50\end{array}$ & $\begin{array}{l}32.90 \\
34.10\end{array}$ & $\begin{array}{l}27.94 \\
25.54\end{array}$ & $\begin{array}{l}27.48 \\
26.86\end{array}$ & $\begin{array}{l}5.28 \\
5.31\end{array}$ \\
\hline 3 & $\begin{array}{l}W \\
R\end{array}$ & $\begin{array}{l}109.67 \\
111.00\end{array}$ & $\begin{array}{l}67.67 \\
67.67\end{array}$ & $\begin{array}{l}4733 \\
4740\end{array}$ & $\begin{array}{l}44.33 \\
43.67\end{array}$ & $\begin{array}{l}27.57 \\
26.20\end{array}$ & $\begin{array}{l}26.30 \\
25.17\end{array}$ & $\begin{array}{l}30.54 \\
24.20\end{array}$ & $\begin{array}{l}4.79 \\
5.35\end{array}$ \\
\hline 4 & $\begin{array}{l}\mathrm{W} \\
\mathrm{R}\end{array}$ & $\begin{array}{l}108.33 \\
110.33\end{array}$ & $\begin{array}{l}67.67 \\
67.67\end{array}$ & $\begin{array}{l}4577 \\
4353\end{array}$ & $\begin{array}{l}44.83 \\
44.33\end{array}$ & $\begin{array}{l}26.67 \\
25.17\end{array}$ & $\begin{array}{l}26.59 \\
25.37\end{array}$ & $\begin{array}{l}26.73 \\
26.70\end{array}$ & $\begin{array}{l}5.17 \\
5.01\end{array}$ \\
\hline 6 & $\begin{array}{l}\mathrm{W} \\
\mathrm{R}\end{array}$ & $\begin{array}{l}105.00 \\
104.00\end{array}$ & $\begin{array}{l}65.67 \\
65.67\end{array}$ & $\begin{array}{l}4397 \\
4517\end{array}$ & $\begin{array}{l}46.50 \\
45.83\end{array}$ & $\begin{array}{l}30.37 \\
32.97\end{array}$ & $\begin{array}{l}24.37 \\
23.73\end{array}$ & $\begin{array}{l}24.85 \\
24.95\end{array}$ & $\begin{array}{l}5.79 \\
5.83\end{array}$ \\
\hline 7 & $\begin{array}{l}W \\
R\end{array}$ & $\begin{array}{l}110.00 \\
113.67\end{array}$ & $\begin{array}{l}64.67 \\
65.00\end{array}$ & $\begin{array}{l}4670 \\
4590\end{array}$ & $\begin{array}{l}44.33 \\
41.83\end{array}$ & $\begin{array}{l}30.90 \\
32.53\end{array}$ & $\begin{array}{l}25.28 \\
24.15\end{array}$ & $\begin{array}{l}26.75 \\
25.20\end{array}$ & $\begin{array}{l}5.73 \\
5.62\end{array}$ \\
\hline 8 & $\begin{array}{l}W \\
R\end{array}$ & $\begin{array}{l}114.00 \\
119.67\end{array}$ & $\begin{array}{l}66.33 \\
66.33\end{array}$ & $\begin{array}{l}4610 \\
4517\end{array}$ & $\begin{array}{l}45.83 \\
45.00\end{array}$ & $\begin{array}{l}32.33 \\
32.90\end{array}$ & $\begin{array}{l}26.89 \\
24.68\end{array}$ & $\begin{array}{l}29.80 \\
27.24\end{array}$ & $\begin{array}{l}5.29 \\
5.54\end{array}$ \\
\hline 9 & $\begin{array}{l}W \\
R\end{array}$ & $\begin{array}{l}112.33 \\
113.00\end{array}$ & $\begin{array}{l}68.00 \\
68.33\end{array}$ & $\begin{array}{l}5013 \\
5036\end{array}$ & $\begin{array}{l}43.17 \\
43.33\end{array}$ & $\begin{array}{l}30.33 \\
30.83\end{array}$ & $\begin{array}{l}27.71 \\
26.90\end{array}$ & $\begin{array}{l}29.14 \\
26.10\end{array}$ & $\begin{array}{l}5.61 \\
5.48\end{array}$ \\
\hline 10 & $\begin{array}{l}\mathrm{W} \\
\mathrm{R}\end{array}$ & $\begin{array}{l}113.00 \\
113.33\end{array}$ & $\begin{array}{l}66.67 \\
66.00\end{array}$ & $\begin{array}{l}5177 \\
4967\end{array}$ & $\begin{array}{l}42.83 \\
42.66\end{array}$ & $\begin{array}{l}31.60 \\
33.13\end{array}$ & $\begin{array}{l}28.46 \\
26.77\end{array}$ & $\begin{array}{l}28.03 \\
25.91\end{array}$ & $\begin{array}{l}5.81 \\
5.65\end{array}$ \\
\hline 11 & $\begin{array}{l}W \\
R\end{array}$ & $\begin{array}{l}116.00 \\
113.50\end{array}$ & $\begin{array}{l}65.00 \\
65.00\end{array}$ & $\begin{array}{l}4885 \\
4785\end{array}$ & $\begin{array}{l}47.25 \\
46.50\end{array}$ & $\begin{array}{l}34.95 \\
36.05\end{array}$ & $\begin{array}{l}27.22 \\
25.78\end{array}$ & $\begin{array}{l}28.13 \\
30.04\end{array}$ & $\begin{array}{l}4.09 \\
4.00\end{array}$ \\
\hline 12 & $\begin{array}{l}W \\
R\end{array}$ & $\begin{array}{l}117.50 \\
117.50\end{array}$ & $\begin{array}{l}66.00 \\
66.00\end{array}$ & $\begin{array}{l}4670 \\
5115\end{array}$ & $\begin{array}{l}44.25 \\
43.25\end{array}$ & $\begin{array}{l}35.75 \\
35.75\end{array}$ & $\begin{array}{l}28.22 \\
27.27\end{array}$ & $\begin{array}{l}29.71 \\
31.65\end{array}$ & $\begin{array}{l}4.29 \\
3.87\end{array}$ \\
\hline
\end{tabular}


APPENDIX 1 (cont.)

\begin{tabular}{|c|c|c|c|c|c|c|c|c|c|}
\hline \multirow[b]{3}{*}{ Pair } & \multirow[b]{3}{*}{$\begin{array}{l}\text { Lemma } \\
\text { Colour }\end{array}$} & \multicolumn{3}{|c|}{ Agronomic Characters } & \multicolumn{5}{|c|}{ Grain Quality Characteristics } \\
\hline & & \multicolumn{3}{|c|}{1984} & \multicolumn{3}{|c|}{1984} & \multicolumn{2}{|c|}{1983} \\
\hline & & $\begin{array}{l}\text { Height } \\
(\mathrm{cm})\end{array}$ & $\begin{array}{l}\text { Heading } \\
\text { date } \\
\text { (days) }\end{array}$ & $\begin{array}{l}\text { Yield } \\
\text { (kg/ha) }\end{array}$ & $\begin{array}{l}\text { Test wt } \\
(\mathrm{kg} / \mathrm{hL})\end{array}$ & $\begin{array}{c}1000 \text { kerne1 } \\
\text { wt }(\mathrm{g})\end{array}$ & $\underset{\%}{\mathrm{Hu} 11}$ & $\underset{\%}{\mathrm{Hu} 11}$ & $\begin{array}{c}\text { Oi1 } \\
\%\end{array}$ \\
\hline 13 & $\begin{array}{l}\mathrm{W} \\
\mathrm{R}\end{array}$ & $\begin{array}{l}113.00 \\
112.00\end{array}$ & $\begin{array}{l}61.33 \\
61.33\end{array}$ & $\begin{array}{l}4990 \\
5023\end{array}$ & $\begin{array}{l}48.33 \\
47.83\end{array}$ & $\begin{array}{l}30.00 \\
29.10\end{array}$ & $\begin{array}{l}27.90 \\
26.67\end{array}$ & $\begin{array}{l}27.52 \\
26.64\end{array}$ & $\begin{array}{l}5.35 \\
5.08\end{array}$ \\
\hline 14 & $\begin{array}{l}\mathrm{W} \\
\mathrm{R}\end{array}$ & $\begin{array}{l}109.67 \\
112.00\end{array}$ & $\begin{array}{l}62.33 \\
62.33\end{array}$ & $\begin{array}{l}4807 \\
4957\end{array}$ & $\begin{array}{l}47.50 \\
47.17\end{array}$ & $\begin{array}{l}29.10 \\
28.70\end{array}$ & $\begin{array}{l}28.12 \\
26.60\end{array}$ & $\begin{array}{l}28.46 \\
26.68\end{array}$ & $\begin{array}{l}4.59 \\
4.61\end{array}$ \\
\hline 15 & $\begin{array}{l}\mathrm{W} \\
\mathrm{R}\end{array}$ & $\begin{array}{l}113.00 \\
112.33\end{array}$ & $\begin{array}{l}61.67 \\
61.33\end{array}$ & $\begin{array}{l}4913 \\
4836\end{array}$ & $\begin{array}{l}47.00 \\
46.17\end{array}$ & $\begin{array}{l}28.53 \\
27.73\end{array}$ & $\begin{array}{l}26.91 \\
25.22\end{array}$ & $\begin{array}{l}29.12 \\
25.67\end{array}$ & $\begin{array}{l}4.51 \\
4.89\end{array}$ \\
\hline 16 & $\begin{array}{l}\mathrm{W} \\
\mathrm{R}\end{array}$ & $\begin{array}{l}108.00 \\
109.00\end{array}$ & $\begin{array}{l}65.67 \\
65.67\end{array}$ & $\begin{array}{l}4593 \\
4653\end{array}$ & $\begin{array}{l}43.33 \\
43.17\end{array}$ & $\begin{array}{l}34.13 \\
35.30\end{array}$ & $\begin{array}{l}27.47 \\
26.58\end{array}$ & $\begin{array}{l}31.76 \\
27.76\end{array}$ & $\begin{array}{l}4.03 \\
4.26\end{array}$ \\
\hline 17 & $\begin{array}{l}\mathrm{W} \\
\mathrm{R}\end{array}$ & $\begin{array}{l}114.50 \\
113.00\end{array}$ & $\begin{array}{l}63.50 \\
63.50\end{array}$ & $\begin{array}{l}5070 \\
5035\end{array}$ & $\begin{array}{l}45.00 \\
44.00\end{array}$ & $\begin{array}{l}33.10 \\
30.95\end{array}$ & $\begin{array}{l}27.59 \\
27.24\end{array}$ & $\begin{array}{l}30.84 \\
30.07\end{array}$ & $\begin{array}{l}4.43 \\
5.13\end{array}$ \\
\hline 18 & $\begin{array}{l}\mathrm{W} \\
\mathrm{R}\end{array}$ & $\begin{array}{l}108.67 \\
109.33\end{array}$ & $\begin{array}{l}63.33 \\
62.66\end{array}$ & $\begin{array}{l}5367 \\
4990\end{array}$ & $\begin{array}{l}45.00 \\
44.00\end{array}$ & $\begin{array}{l}30.50 \\
28.40\end{array}$ & $\begin{array}{l}26.56 \\
24.57\end{array}$ & $\begin{array}{l}28.71 \\
27.81\end{array}$ & $\begin{array}{l}5.00 \\
5.12\end{array}$ \\
\hline 19 & $\begin{array}{l}\mathrm{W} \\
\mathrm{R}\end{array}$ & $\begin{array}{l}111.67 \\
110.33\end{array}$ & $\begin{array}{l}63.33 \\
63.33\end{array}$ & $\begin{array}{l}5003 \\
5006\end{array}$ & $\begin{array}{l}45.17 \\
44.17\end{array}$ & $\begin{array}{l}29.60 \\
28.20\end{array}$ & $\begin{array}{l}26.42 \\
26.21\end{array}$ & $\begin{array}{l}26.96 \\
25.68\end{array}$ & $\begin{array}{l}5.31 \\
5.32\end{array}$ \\
\hline 20 & $\begin{array}{l}\mathrm{W} \\
\mathrm{R}\end{array}$ & $\begin{array}{l}117.67 \\
115.67\end{array}$ & $\begin{array}{l}67.33 \\
67.33\end{array}$ & $\begin{array}{l}4623 \\
4843\end{array}$ & $\begin{array}{l}45.00 \\
44.17\end{array}$ & $\begin{array}{l}29.73 \\
30.10\end{array}$ & $\begin{array}{l}26.21 \\
24.84\end{array}$ & $\begin{array}{l}24.82 \\
28.81\end{array}$ & $\begin{array}{l}5.07 \\
5.09\end{array}$ \\
\hline 21 & $\begin{array}{l}\mathrm{W} \\
\mathrm{R}\end{array}$ & $\begin{array}{l}117.00 \\
119.33\end{array}$ & $\begin{array}{l}67.00 \\
67.67\end{array}$ & $\begin{array}{l}4580 \\
4613\end{array}$ & $\begin{array}{l}46.33 \\
45.00\end{array}$ & $\begin{array}{l}30.70 \\
31.13\end{array}$ & $\begin{array}{l}26.05 \\
25.54\end{array}$ & $\begin{array}{l}26.39 \\
27.85\end{array}$ & $\begin{array}{l}5.30 \\
5.22\end{array}$ \\
\hline 22 & $\begin{array}{l}\mathrm{W} \\
\mathrm{R}\end{array}$ & $\begin{array}{l}113.00 \\
114.33\end{array}$ & $\begin{array}{l}66.00 \\
67.00\end{array}$ & $\begin{array}{l}4916 \\
5083\end{array}$ & $\begin{array}{l}44.83 \\
44.50\end{array}$ & $\begin{array}{l}28.83 \\
28.07\end{array}$ & $\begin{array}{l}26.33 \\
25.10\end{array}$ & $\begin{array}{l}26.61 \\
27.74\end{array}$ & $\begin{array}{l}5.21 \\
5.36\end{array}$ \\
\hline 23 & $\begin{array}{l}\mathrm{W} \\
\mathrm{R}\end{array}$ & $\begin{array}{l}115.33 \\
113.00\end{array}$ & $\begin{array}{l}66.33 \\
66.33\end{array}$ & $\begin{array}{l}4897 \\
4877\end{array}$ & $\begin{array}{l}48.83 \\
47.17\end{array}$ & $\begin{array}{l}29.47 \\
29.47\end{array}$ & $\begin{array}{l}25.48 \\
24.58\end{array}$ & $\begin{array}{l}32.25 \\
29.68\end{array}$ & - \\
\hline
\end{tabular}


APPENDIX 1 (cont.)

\begin{tabular}{|c|c|c|c|c|c|c|c|c|c|}
\hline \multirow[b]{3}{*}{ Pair } & \multirow[b]{3}{*}{$\begin{array}{l}\text { Lemma } \\
\text { Colour }\end{array}$} & \multicolumn{3}{|c|}{ Agronomic Characters } & \multicolumn{5}{|c|}{ Grain Quality Characteristics } \\
\hline & & \multicolumn{3}{|c|}{1984} & \multicolumn{3}{|c|}{1984} & \multicolumn{2}{|c|}{1983} \\
\hline & & $\begin{array}{l}\text { Height } \\
(\mathrm{cm})\end{array}$ & $\begin{array}{l}\text { Heading } \\
\text { date } \\
\text { (days) }\end{array}$ & $\begin{array}{c}\text { Yie1d } \\
(\mathrm{kg} / \mathrm{ha})\end{array}$ & $\begin{array}{l}\text { Test wt } \\
(\mathrm{kg} / \mathrm{hL})\end{array}$ & $\begin{array}{l}1000 \text { kernel } \\
\text { wt }(\mathrm{g})\end{array}$ & $\underset{\%}{\mathrm{Hu} 11}$ & $\underset{\%}{\mathrm{Hu} 11}$ & 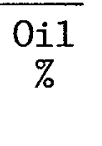 \\
\hline 24 & $\begin{array}{l}\mathrm{W} \\
\mathrm{R}\end{array}$ & $\begin{array}{l}120.00 \\
121.67\end{array}$ & $\begin{array}{l}66.67 \\
66.00\end{array}$ & $\begin{array}{l}5453 \\
5450\end{array}$ & $\begin{array}{l}46.17 \\
45.50\end{array}$ & $\begin{array}{l}30.67 \\
31.30\end{array}$ & $\begin{array}{l}25.91 \\
25.50\end{array}$ & $\begin{array}{l}25.85 \\
30.39\end{array}$ & $\begin{array}{l}5.25 \\
4.80\end{array}$ \\
\hline 25 & $\begin{array}{l}\mathrm{W} \\
\mathrm{R}\end{array}$ & $\begin{array}{l}115.50 \\
115.50\end{array}$ & $\begin{array}{l}63.00 \\
62.50\end{array}$ & $\begin{array}{l}5210 \\
5230\end{array}$ & $\begin{array}{l}46.00 \\
45.75\end{array}$ & $\begin{array}{l}29.40 \\
29.90\end{array}$ & $\begin{array}{l}26.33 \\
24.81\end{array}$ & $\begin{array}{l}29.26 \\
26.06\end{array}$ & $\begin{array}{l}4.74 \\
5.28\end{array}$ \\
\hline 26 & $\begin{array}{l}\mathrm{W} \\
\mathrm{R}\end{array}$ & $\begin{array}{l}108.00 \\
109.50\end{array}$ & $\begin{array}{l}63.50 \\
64.00\end{array}$ & $\begin{array}{l}5155 \\
5365\end{array}$ & $\begin{array}{l}44.75 \\
41.25\end{array}$ & $\begin{array}{l}29.15 \\
30.10\end{array}$ & $\begin{array}{l}27.53 \\
26.80\end{array}$ & $\begin{array}{l}26.48 \\
27.03\end{array}$ & $\begin{array}{l}5.01 \\
4.97\end{array}$ \\
\hline 27 & $\begin{array}{l}\mathrm{W} \\
\mathrm{R}\end{array}$ & $\begin{array}{l}107.33 \\
104.33\end{array}$ & $\begin{array}{l}65.00 \\
64.00\end{array}$ & $\begin{array}{l}4213 \\
4666\end{array}$ & $\begin{array}{l}45.67 \\
46.83\end{array}$ & $\begin{array}{l}37.33 \\
32.83\end{array}$ & $\begin{array}{l}27.34 \\
25.67\end{array}$ & $\begin{array}{l}26.38 \\
24.06\end{array}$ & $\begin{array}{l}4.16 \\
4.07\end{array}$ \\
\hline 28 & $\begin{array}{l}W \\
R\end{array}$ & $\begin{array}{l}113.00 \\
109.00\end{array}$ & $\begin{array}{l}66.67 \\
66.00\end{array}$ & $\begin{array}{l}4773 \\
4803\end{array}$ & $\begin{array}{l}47.17 \\
45.17\end{array}$ & $\begin{array}{l}33.53 \\
34.23\end{array}$ & $\begin{array}{l}26.86 \\
26.04\end{array}$ & $\begin{array}{l}23.57 \\
25.22\end{array}$ & $\begin{array}{l}5.59 \\
4.00\end{array}$ \\
\hline 29 & $\begin{array}{l}W \\
R\end{array}$ & $\begin{array}{l}108.00 \\
108.00\end{array}$ & $\begin{array}{l}66.00 \\
66.00\end{array}$ & $\begin{array}{l}4933 \\
4846\end{array}$ & $\begin{array}{l}45.00 \\
44.50\end{array}$ & $\begin{array}{l}35.70 \\
37.40\end{array}$ & $\begin{array}{l}27.22 \\
25.75\end{array}$ & $\begin{array}{l}28.72 \\
25.37\end{array}$ & $\begin{array}{l}3.99 \\
4.24\end{array}$ \\
\hline 30 & $\begin{array}{l}\mathrm{W} \\
\mathrm{R}\end{array}$ & $\begin{array}{l}107.00 \\
106.67\end{array}$ & $\begin{array}{l}65.33 \\
65.33\end{array}$ & $\begin{array}{l}5483 \\
5556\end{array}$ & $\begin{array}{l}43.17 \\
43.67\end{array}$ & $\begin{array}{l}24.70 \\
26.10\end{array}$ & $\begin{array}{l}28.41 \\
26.76\end{array}$ & $\begin{array}{l}26.44 \\
26.73\end{array}$ & $\begin{array}{l}4.67 \\
4.50\end{array}$ \\
\hline 32 & $\begin{array}{l}\mathrm{W} \\
\mathrm{R}\end{array}$ & $\begin{array}{l}111.00 \\
115.00\end{array}$ & $\begin{array}{l}62.67 \\
63.67\end{array}$ & $\begin{array}{l}4777 \\
4797\end{array}$ & $\begin{array}{l}46.50 \\
47.33\end{array}$ & $\begin{array}{l}32.97 \\
38.10\end{array}$ & $\begin{array}{l}26.58 \\
25.14\end{array}$ & $\begin{array}{l}28.31 \\
28.32\end{array}$ & $\begin{array}{l}3.90 \\
4.13\end{array}$ \\
\hline 33 & $\begin{array}{l}\mathrm{W} \\
\mathrm{R}\end{array}$ & $\begin{array}{l}107.00 \\
107.50\end{array}$ & $\begin{array}{l}64.00 \\
64.00\end{array}$ & $\begin{array}{l}5500 \\
4830\end{array}$ & $\begin{array}{l}46.75 \\
44.50\end{array}$ & $\begin{array}{l}30.60 \\
30.25\end{array}$ & $\begin{array}{l}26.95 \\
25.73\end{array}$ & $\begin{array}{l}27.10 \\
28.71\end{array}$ & $\begin{array}{l}4.84 \\
5.01\end{array}$ \\
\hline 34 & $\begin{array}{l}\mathrm{W} \\
\mathrm{R}\end{array}$ & $\begin{array}{l}110.33 \\
109.00\end{array}$ & $\begin{array}{l}61.67 \\
61.67\end{array}$ & $\begin{array}{l}4880 \\
4810\end{array}$ & $\begin{array}{l}45.83 \\
45.33\end{array}$ & $\begin{array}{l}31.83 \\
32.70\end{array}$ & $\begin{array}{l}25.67 \\
24.64\end{array}$ & $\begin{array}{l}24.21 \\
24.11\end{array}$ & $\begin{array}{l}5.65 \\
5.66\end{array}$ \\
\hline
\end{tabular}


APPENDIX 1 (cont.)

\begin{tabular}{|c|c|c|c|c|c|c|c|c|c|}
\hline \multirow[b]{3}{*}{ Pair } & \multirow[b]{3}{*}{$\begin{array}{l}\text { Lemma } \\
\text { Colour }\end{array}$} & \multicolumn{3}{|c|}{ Agronomic Characters } & \multicolumn{5}{|c|}{ Grain Quality Characteristics } \\
\hline & & \multicolumn{3}{|c|}{1984} & \multicolumn{3}{|c|}{1984} & \multicolumn{2}{|c|}{1983} \\
\hline & & $\begin{array}{l}\text { Height } \\
(\mathrm{cm})\end{array}$ & $\begin{array}{l}\text { Heading } \\
\text { date } \\
\text { (days) }\end{array}$ & $\begin{array}{c}\text { Yield } \\
(\mathrm{kg} / \mathrm{ha})\end{array}$ & $\begin{array}{l}\text { Test wt } \\
(\mathrm{kg} / \mathrm{hL})\end{array}$ & $\begin{array}{c}1000 \text { kerne1 } \\
\text { wt }(\mathrm{g})\end{array}$ & $\begin{array}{c}\mathrm{Hu} 11 \\
\%\end{array}$ & $\underset{\%}{\mathrm{Hu} 11}$ & $\begin{array}{c}0 i 1 \\
\%\end{array}$ \\
\hline 35 & $\begin{array}{l}\mathrm{W} \\
\mathrm{R}\end{array}$ & $\begin{array}{l}105.50 \\
111.00\end{array}$ & $\begin{array}{l}61.00 \\
61.00\end{array}$ & $\begin{array}{l}5375 \\
5530\end{array}$ & $\begin{array}{l}44.50 \\
45.50\end{array}$ & $\begin{array}{l}30.95 \\
30.25\end{array}$ & $\begin{array}{l}23.29 \\
24.82\end{array}$ & $\begin{array}{l}25.01 \\
24.34\end{array}$ & $\begin{array}{l}5.45 \\
5.58\end{array}$ \\
\hline 36 & $\begin{array}{l}\mathrm{W} \\
\mathrm{R}\end{array}$ & $\begin{array}{l}114.50 \\
113.50\end{array}$ & $\begin{array}{l}61.00 \\
61.00\end{array}$ & $\begin{array}{l}5175 \\
5245\end{array}$ & $\begin{array}{l}45.75 \\
45.25\end{array}$ & $\begin{array}{l}33.65 \\
34.20\end{array}$ & $\begin{array}{l}25.40 \\
24.27\end{array}$ & $\begin{array}{l}27.21 \\
26.47\end{array}$ & $\begin{array}{l}5.31 \\
5.37\end{array}$ \\
\hline 38 & $\begin{array}{l}\mathrm{W} \\
\mathrm{R}\end{array}$ & $\begin{array}{l}107.33 \\
110.67\end{array}$ & $\begin{array}{l}61.00 \\
61.33\end{array}$ & $\begin{array}{l}5500 \\
5357\end{array}$ & $\begin{array}{l}47.33 \\
45.50\end{array}$ & $\begin{array}{l}28.30 \\
29.63\end{array}$ & $\begin{array}{l}26.48 \\
24.34\end{array}$ & $\begin{array}{l}25.43 \\
24.28\end{array}$ & $\begin{array}{l}5.49 \\
5.40\end{array}$ \\
\hline 39 & $\begin{array}{l}\mathrm{W} \\
\mathrm{R}\end{array}$ & $\begin{array}{l}112.67 \\
109.67\end{array}$ & $\begin{array}{l}61.33 \\
61.33\end{array}$ & $\begin{array}{l}5297 \\
4997\end{array}$ & $\begin{array}{l}48.17 \\
47.00\end{array}$ & $\begin{array}{l}28.97 \\
29.17\end{array}$ & $\begin{array}{l}26.02 \\
24.60\end{array}$ & $\begin{array}{l}27.53 \\
23.58\end{array}$ & $\begin{array}{l}5.35 \\
5.52\end{array}$ \\
\hline 40 & $\begin{array}{l}\mathrm{W} \\
\mathrm{R}\end{array}$ & $\begin{array}{l}107.50 \\
108.50\end{array}$ & $\begin{array}{l}61.50 \\
62.00\end{array}$ & $\begin{array}{l}4335 \\
4630\end{array}$ & $\begin{array}{l}48.25 \\
48.50\end{array}$ & $\begin{array}{l}28.95 \\
31.10\end{array}$ & $\begin{array}{l}25.52 \\
24.26\end{array}$ & $\begin{array}{l}27.52 \\
25.21\end{array}$ & $\begin{array}{l}5.36 \\
5.71\end{array}$ \\
\hline
\end{tabular}

Twhite (W) and red (R) 
APPENDIX 2. Mean values for the agronomic and grain quality characteristics of the yellow versus red near-isogenic pairs of lines grown at Glenlea, Manitoba in 1983 and 1984

\begin{tabular}{|c|c|c|c|c|c|c|c|c|c|}
\hline \multirow[b]{3}{*}{ Pair } & \multirow[b]{3}{*}{$\begin{array}{l}\text { Lemma } \\
\text { Colour }\end{array}$} & \multicolumn{3}{|c|}{ Agronomic Characters } & \multicolumn{5}{|c|}{ Grain Quality Characteristics } \\
\hline & & \multicolumn{3}{|c|}{1984} & \multicolumn{3}{|c|}{1984} & \multicolumn{2}{|c|}{1983} \\
\hline & & $\begin{array}{l}\text { Height } \\
\text { (cm) }\end{array}$ & $\begin{array}{c}\text { Heading } \\
\text { date } \\
\text { (days) }\end{array}$ & $\begin{array}{l}\text { Yield } \\
\text { (kg/ha) }\end{array}$ & $\begin{array}{l}\text { Test wt } \\
(\mathrm{kg} / \mathrm{hL})\end{array}$ & $\begin{array}{l}1000 \text { kerne1 } \\
\text { wt }(\mathrm{g})\end{array}$ & $\underset{\%}{\mathrm{Hu} 11}$ & $\underset{\%}{\mathrm{Hu} 11}$ & $\underset{\%}{0 i 1}$ \\
\hline 1 & $\begin{array}{l}\mathrm{YT} \\
\mathrm{R}\end{array}$ & $\begin{array}{l}111.67 \\
110.00\end{array}$ & $\begin{array}{l}66.00 \\
68.00\end{array}$ & $\begin{array}{l}5253 \\
4763\end{array}$ & $\begin{array}{l}42.67 \\
41.67\end{array}$ & $\begin{array}{l}28.73 \\
28.93\end{array}$ & $\begin{array}{l}28.01 \\
27.19\end{array}$ & $\begin{array}{l}27.18 \\
34.42\end{array}$ & - \\
\hline 3 & $\begin{array}{l}\mathrm{Y} \\
\mathrm{R}\end{array}$ & $\begin{array}{l}108.00 \\
108.00\end{array}$ & $\begin{array}{l}65.00 \\
64.67\end{array}$ & $\begin{array}{l}5243 \\
5320\end{array}$ & $\begin{array}{l}44.17 \\
44.33\end{array}$ & $\begin{array}{l}28.73 \\
29.73\end{array}$ & $\begin{array}{l}28.75 \\
26.69\end{array}$ & $\begin{array}{l}27.18 \\
34.42\end{array}$ & $\begin{array}{l}5.24 \\
4.70\end{array}$ \\
\hline 5 & $\begin{array}{l}\mathrm{Y} \\
\mathrm{R}\end{array}$ & $\begin{array}{l}107.50 \\
107.50\end{array}$ & $\begin{array}{l}65.50 \\
65.50\end{array}$ & $\begin{array}{l}5315 \\
5110\end{array}$ & $\begin{array}{l}43.00 \\
44.25\end{array}$ & $\begin{array}{l}31.05 \\
32.10\end{array}$ & $\begin{array}{l}29.52 \\
27.23\end{array}$ & $\begin{array}{l}32.03 \\
28.46\end{array}$ & $\begin{array}{l}5.15 \\
5.46\end{array}$ \\
\hline 9 & $\begin{array}{l}\mathrm{Y} \\
\mathrm{R}\end{array}$ & $\begin{array}{l}117.00 \\
115.50\end{array}$ & $\begin{array}{l}69.00 \\
69.00\end{array}$ & $\begin{array}{l}5290 \\
5025\end{array}$ & $\begin{array}{l}44.25 \\
43.00\end{array}$ & $\begin{array}{l}29.90 \\
28.40\end{array}$ & $\begin{array}{l}28.82 \\
27.35\end{array}$ & $\begin{array}{l}30.11 \\
29.59\end{array}$ & $\begin{array}{l}5.53 \\
5.37\end{array}$ \\
\hline 11 & $\begin{array}{l}\mathrm{Y} \\
\mathrm{R}\end{array}$ & $\begin{array}{l}112.00 \\
112.33\end{array}$ & $\begin{array}{l}65.33 \\
66.33\end{array}$ & $\begin{array}{l}5146 \\
5003\end{array}$ & $\begin{array}{l}45.17 \\
43.67\end{array}$ & $\begin{array}{l}29.26 \\
31.63\end{array}$ & $\begin{array}{l}27.48 \\
26.54\end{array}$ & $\begin{array}{l}28.72 \\
32.15\end{array}$ & $\begin{array}{l}5.09 \\
4.73\end{array}$ \\
\hline 14 & $\begin{array}{l}\mathrm{Y} \\
\mathrm{R}\end{array}$ & $\begin{array}{l}112.33 \\
113.67\end{array}$ & $\begin{array}{l}65.33 \\
65.33\end{array}$ & $\begin{array}{l}5183 \\
5326\end{array}$ & $\begin{array}{l}45.50 \\
44.83\end{array}$ & $\begin{array}{l}30.13 \\
30.06\end{array}$ & $\begin{array}{l}27.34 \\
26.21\end{array}$ & $\begin{array}{l}30.10 \\
26.60\end{array}$ & $\begin{array}{l}4.93 \\
5.19\end{array}$ \\
\hline 15 & $\begin{array}{l}\mathrm{Y} \\
\mathrm{R}\end{array}$ & $\begin{array}{l}109.00 \\
108.00\end{array}$ & $\begin{array}{l}66.50 \\
66.50\end{array}$ & $\begin{array}{l}5335 \\
4765\end{array}$ & $\begin{array}{l}45.00 \\
45.00\end{array}$ & $\begin{array}{l}29.60 \\
30.15\end{array}$ & $\begin{array}{l}27.36 \\
26.62\end{array}$ & - & $\begin{array}{l}4.63 \\
4.74\end{array}$ \\
\hline 16 & $\begin{array}{l}\mathrm{Y} \\
\mathrm{R}\end{array}$ & $\begin{array}{l}108.33 \\
106.33\end{array}$ & $\begin{array}{l}67.33 \\
67.33\end{array}$ & $\begin{array}{l}4953 \\
5010\end{array}$ & $\begin{array}{l}45.67 \\
44.67\end{array}$ & $\begin{array}{l}31.00 \\
30.13\end{array}$ & $\begin{array}{l}27.92 \\
26.70\end{array}$ & $\begin{array}{l}29.15 \\
27.08\end{array}$ & $\begin{array}{l}5.29 \\
5.42\end{array}$ \\
\hline 17 & $\begin{array}{l}\mathrm{Y} \\
\mathrm{R}\end{array}$ & $\begin{array}{l}107.67 \\
104.00\end{array}$ & $\begin{array}{l}67.67 \\
67.67\end{array}$ & $\begin{array}{l}4890 \\
5196\end{array}$ & $\begin{array}{l}45.83 \\
44.67\end{array}$ & $\begin{array}{l}28.90 \\
29.70\end{array}$ & $\begin{array}{l}28.46 \\
28.14\end{array}$ & $\begin{array}{l}29.29 \\
27.88\end{array}$ & $\begin{array}{l}5.20 \\
5.14\end{array}$ \\
\hline 18 & $\begin{array}{l}\mathrm{Y} \\
\mathrm{R}\end{array}$ & $\begin{array}{l}114.33 \\
109.67\end{array}$ & $\begin{array}{l}66.33 \\
66.33\end{array}$ & $\begin{array}{l}5020 \\
5113\end{array}$ & $\begin{array}{l}46.50 \\
44.33\end{array}$ & $\begin{array}{l}31.46 \\
31.56\end{array}$ & $\begin{array}{l}27.88 \\
27.74\end{array}$ & $\begin{array}{l}30.38 \\
28.11\end{array}$ & $\begin{array}{l}4.89 \\
5.27\end{array}$ \\
\hline 19 & $\begin{array}{l}\mathrm{Y} \\
\mathrm{R}\end{array}$ & $\begin{array}{l}112.00 \\
113.00\end{array}$ & $\begin{array}{l}67.33 \\
67.67\end{array}$ & $\begin{array}{l}5153 \\
5000\end{array}$ & $\begin{array}{l}44.67 \\
43.17\end{array}$ & $\begin{array}{l}30.93 \\
31.26\end{array}$ & $\begin{array}{l}27.85 \\
26.86\end{array}$ & $\begin{array}{l}30.57 \\
26.29\end{array}$ & $\begin{array}{l}4.73 \\
5.20\end{array}$ \\
\hline
\end{tabular}


APPENDIX 2.(cont.)

\begin{tabular}{|c|c|c|c|c|c|c|c|c|c|}
\hline \multirow[b]{3}{*}{ Pair } & \multirow[b]{3}{*}{$\begin{array}{l}\text { Lemma } \\
\text { Colour }\end{array}$} & \multicolumn{3}{|c|}{ Agronomic Characters } & \multicolumn{5}{|c|}{ Grain Quality Characteristics } \\
\hline & & \multicolumn{3}{|c|}{1984} & \multicolumn{3}{|c|}{1984} & \multicolumn{2}{|c|}{1983} \\
\hline & & $\begin{array}{l}\text { Height } \\
\quad(\mathrm{cm})\end{array}$ & $\begin{array}{l}\text { Heading } \\
\text { date } \\
\text { (days) }\end{array}$ & $\begin{array}{l}\text { Yield } \\
(\mathrm{kg} / \mathrm{ha})\end{array}$ & $\begin{array}{l}\text { Test wt } \\
(\mathrm{kg} / \mathrm{hL})\end{array}$ & $\begin{array}{c}1000 \text { kerne1 } \\
\text { wt }(\mathrm{g})\end{array}$ & $\underset{\%}{\mathrm{Hu} 11}$ & $\underset{\%}{\mathrm{Hu} 11}$ & $\begin{array}{c}\mathrm{Oi1} \\
\%\end{array}$ \\
\hline 20 & $\begin{array}{l}\mathrm{Y} \\
\mathrm{R}\end{array}$ & $\begin{array}{l}109.67 \\
112.33\end{array}$ & $\begin{array}{l}67.67 \\
67.67\end{array}$ & $\begin{array}{l}4930 \\
5090\end{array}$ & $\begin{array}{l}45.00 \\
43.67\end{array}$ & $\begin{array}{l}29.80 \\
28.77\end{array}$ & $\begin{array}{l}29.44 \\
27.33\end{array}$ & $\begin{array}{l}30.43 \\
32.01\end{array}$ & $\begin{array}{l}4.65 \\
4.70\end{array}$ \\
\hline 21 & $\begin{array}{l}\mathrm{Y} \\
\mathrm{R}\end{array}$ & $\begin{array}{l}114.33 \\
115.00\end{array}$ & $\begin{array}{l}63.33 \\
63.33\end{array}$ & $\begin{array}{l}5416 \\
5503\end{array}$ & $\begin{array}{l}44.67 \\
46.00\end{array}$ & $\begin{array}{l}28.03 \\
28.63\end{array}$ & $\begin{array}{l}29.28 \\
28.02\end{array}$ & $\begin{array}{l}29.15 \\
28.24\end{array}$ & $\begin{array}{l}4.96 \\
5.15\end{array}$ \\
\hline 22 & $\begin{array}{l}\mathrm{Y} \\
\mathrm{R}\end{array}$ & $\begin{array}{l}109.67 \\
112.33\end{array}$ & $\begin{array}{l}65.33 \\
66.00\end{array}$ & $\begin{array}{l}5250 \\
5120\end{array}$ & $\begin{array}{l}44.83 \\
43.83\end{array}$ & $\begin{array}{l}31.70 \\
32.46\end{array}$ & $\begin{array}{l}28.25 \\
27.27\end{array}$ & $\begin{array}{l}29.94 \\
28.92\end{array}$ & $\begin{array}{l}5.00 \\
5.24\end{array}$ \\
\hline 23 & $\begin{array}{l}\mathrm{Y} \\
\mathrm{R}\end{array}$ & $\begin{array}{l}110.00 \\
104.50\end{array}$ & $\begin{array}{l}65.50 \\
66.50\end{array}$ & $\begin{array}{l}5235 \\
5015\end{array}$ & $\begin{array}{l}43.75 \\
43.00\end{array}$ & $\begin{array}{l}28.45 \\
29.60\end{array}$ & $\begin{array}{l}29.54 \\
27.77\end{array}$ & $\begin{array}{l}29.11 \\
29.94\end{array}$ & $\begin{array}{l}5.06 \\
4.95\end{array}$ \\
\hline
\end{tabular}

ף yellow $(Y)$ and red $(R)$ 
APPENDIX 3. Mean values for the agronomic and grain quality characteristics of the yellow versus white near-isogenic pairs of lines grown at Glenlea, Manitoba in 1983 and 1984

\begin{tabular}{|c|c|c|c|c|c|c|c|c|c|}
\hline \multirow[b]{3}{*}{ Pair } & \multirow[b]{3}{*}{$\begin{array}{l}\text { Lemma } \\
\text { Colour }\end{array}$} & \multicolumn{3}{|c|}{ Agronomic Characters } & \multicolumn{5}{|c|}{ Grain Quality Characteristics } \\
\hline & & \multicolumn{3}{|c|}{1984} & \multicolumn{3}{|c|}{1984} & \multicolumn{2}{|c|}{1983} \\
\hline & & $\begin{array}{l}\text { Height } \\
\text { (cm) }\end{array}$ & $\begin{array}{c}\text { Heading } \\
\text { date } \\
\text { (days) }\end{array}$ & $\begin{array}{c}\text { Yield } \\
\text { (kg/ha) }\end{array}$ & $\begin{array}{l}\text { Test wt } \\
(\mathrm{kg} / \mathrm{hL})\end{array}$ & $\begin{array}{l}1000 \text { kernel } \\
\text { wt }(\mathrm{g})\end{array}$ & $\begin{array}{c}\mathrm{Hu} 11 \\
\%\end{array}$ & $\begin{array}{c}\mathrm{Hu} 11 \\
\%\end{array}$ & $\begin{array}{c}\text { Oi1 } \\
\%\end{array}$ \\
\hline 1 & $\begin{array}{l}\mathrm{Y} \uparrow \\
\mathrm{W}\end{array}$ & $\begin{array}{l}116.3 \\
115.7\end{array}$ & $\begin{array}{l}69.33 \\
69.33\end{array}$ & $\begin{array}{l}4953 \\
5143\end{array}$ & $\begin{array}{l}38.17 \\
37.00\end{array}$ & $\begin{array}{l}29.76 \\
27.86\end{array}$ & $\begin{array}{l}29.31 \\
26.93\end{array}$ & $\begin{array}{l}29.59 \\
34.01\end{array}$ & $\begin{array}{l}5.71 \\
4.89\end{array}$ \\
\hline 2 & $\begin{array}{l}\mathrm{Y} \\
\mathrm{W}\end{array}$ & $\begin{array}{l}120.3 \\
119.3\end{array}$ & $\begin{array}{l}69.67 \\
69.00\end{array}$ & $\begin{array}{l}5187 \\
5140\end{array}$ & $\begin{array}{l}36.83 \\
37.17\end{array}$ & $\begin{array}{l}27.46 \\
25.73\end{array}$ & $\begin{array}{l}28.88 \\
27.62\end{array}$ & $\begin{array}{l}29.26 \\
29.01\end{array}$ & $\begin{array}{l}5.64 \\
6.14\end{array}$ \\
\hline 3 & $\begin{array}{l}\mathrm{Y} \\
\mathrm{W}\end{array}$ & $\begin{array}{l}114.0 \\
108.0\end{array}$ & $\begin{array}{l}69.00 \\
69.00\end{array}$ & $\begin{array}{l}4830 \\
4625\end{array}$ & $\begin{array}{l}37.25 \\
38.00\end{array}$ & $\begin{array}{l}29.85 \\
28.85\end{array}$ & $\begin{array}{l}28.52 \\
26.48\end{array}$ & $\begin{array}{l}29.30 \\
30.34\end{array}$ & $\begin{array}{l}5.68 \\
5.53\end{array}$ \\
\hline 4 & $\begin{array}{l}Y \\
W\end{array}$ & $\begin{array}{l}120.0 \\
118.0\end{array}$ & $\begin{array}{l}67.00 \\
67.00\end{array}$ & $\begin{array}{l}4850 \\
4960\end{array}$ & $\begin{array}{l}46.50 \\
47.17\end{array}$ & $\begin{array}{l}32.30 \\
29.97\end{array}$ & $\begin{array}{l}27.71 \\
25.97\end{array}$ & $\begin{array}{l}28.68 \\
26.28\end{array}$ & $\begin{array}{l}5.48 \\
5.62\end{array}$ \\
\hline 5 & $\begin{array}{l}Y \\
W\end{array}$ & $\begin{array}{l}117.7 \\
114.7\end{array}$ & $\begin{array}{l}66.33 \\
66.00\end{array}$ & $\begin{array}{l}4917 \\
5023\end{array}$ & $\begin{array}{l}46.00 \\
46.17\end{array}$ & $\begin{array}{l}31.63 \\
29.43\end{array}$ & $\begin{array}{l}26.29 \\
24.73\end{array}$ & $\begin{array}{l}27.03 \\
27.10\end{array}$ & $\begin{array}{l}5.73 \\
5.74\end{array}$ \\
\hline 6 & $\begin{array}{l}Y \\
W\end{array}$ & $\begin{array}{l}120.3 \\
121.7\end{array}$ & $\begin{array}{l}66.00 \\
66.00\end{array}$ & $\begin{array}{l}4580 \\
5100\end{array}$ & $\begin{array}{l}46.17 \\
47.67\end{array}$ & $\begin{array}{l}30.97 \\
29.43\end{array}$ & $\begin{array}{l}26.43 \\
26.10\end{array}$ & $\begin{array}{l}28.64 \\
25.46\end{array}$ & $\begin{array}{l}5.43 \\
5.97\end{array}$ \\
\hline 7 & $\begin{array}{l}\mathrm{Y} \\
\mathrm{W}\end{array}$ & $\begin{array}{l}117.0 \\
114.7\end{array}$ & $\begin{array}{l}66.33 \\
66.00\end{array}$ & $\begin{array}{l}5180 \\
4953\end{array}$ & $\begin{array}{l}46.33 \\
46.83\end{array}$ & $\begin{array}{l}31.60 \\
30.47\end{array}$ & $\begin{array}{l}26.72 \\
24.96\end{array}$ & $\begin{array}{l}28.61 \\
23.9 .8\end{array}$ & $\begin{array}{l}5.34 \\
5.61\end{array}$ \\
\hline 8 & $\begin{array}{l}\mathrm{Y} \\
\mathrm{W}\end{array}$ & $\begin{array}{l}123.6 \\
122.3\end{array}$ & $\begin{array}{l}64.33 \\
64.33\end{array}$ & $\begin{array}{l}4917 \\
5187\end{array}$ & $\begin{array}{l}46.50 \\
47.50\end{array}$ & $\begin{array}{l}32.87 \\
30.57\end{array}$ & $\begin{array}{l}26.14 \\
24.49\end{array}$ & $\begin{array}{l}27.47 \\
23.36\end{array}$ & -- \\
\hline 9 & $\begin{array}{l}\mathrm{Y} \\
\mathrm{W}\end{array}$ & $\begin{array}{l}118.7 \\
119.0\end{array}$ & $\begin{array}{l}64.33 \\
62.67\end{array}$ & $\begin{array}{l}5017 \\
4917\end{array}$ & $\begin{array}{l}45.50 \\
46.67\end{array}$ & $\begin{array}{l}31.70 \\
34.46\end{array}$ & $\begin{array}{l}26.35 \\
24.08\end{array}$ & $\begin{array}{l}27.50 \\
29.42\end{array}$ & -- \\
\hline 10 & $\begin{array}{l}\mathrm{Y} \\
\mathrm{W}\end{array}$ & $\begin{array}{l}119.7 \\
118.3\end{array}$ & $\begin{array}{l}68.67 \\
68.00\end{array}$ & $\begin{array}{l}5003 \\
4880\end{array}$ & $\begin{array}{l}40.83 \\
41.33\end{array}$ & $\begin{array}{l}31.56 \\
29.46\end{array}$ & $\begin{array}{l}27.99 \\
26.00\end{array}$ & $\begin{array}{l}29.09 \\
32.01\end{array}$ & $\begin{array}{l}5.44 \\
5.10\end{array}$ \\
\hline
\end{tabular}

T yellow (Y) and white (W) lemma colour 
APPENDIX 4. Mean values for the agronomic and grain quality characteristics of the black versus non-black near-isogenic pairs of lines grown at Glenlea, Manitoba in 1983 and 1984

\begin{tabular}{|c|c|c|c|c|c|c|c|c|c|}
\hline \multirow[b]{3}{*}{ Pair } & \multirow[b]{3}{*}{$\begin{array}{l}\text { Lemma } \\
\text { Colour }\end{array}$} & \multicolumn{3}{|c|}{ Agronomic Characters } & \multicolumn{5}{|c|}{ Grain Quality Characteristics } \\
\hline & & \multicolumn{3}{|c|}{1984} & \multicolumn{3}{|c|}{1984} & \multicolumn{2}{|c|}{1983} \\
\hline & & $\begin{array}{l}\text { Height } \\
(\mathrm{cm})\end{array}$ & $\begin{array}{l}\text { Heading } \\
\text { date } \\
\text { (days) }\end{array}$ & $\begin{array}{c}\text { Yield } \\
\text { (kg/ha) }\end{array}$ & $\begin{array}{l}\text { Test wt } \\
(\mathrm{kg} / \mathrm{hL})\end{array}$ & $\begin{array}{l}1000 \text { kernel } \\
\text { wt }(\mathrm{g})\end{array}$ & $\underset{\%}{\mathrm{Hu} 11}$ & $\underset{\%}{\mathrm{Hu} 11}$ & $\begin{array}{c}0 i 1 \\
\%\end{array}$ \\
\hline 1 & $\begin{array}{l}\text { LBI } \\
\text { B1 }\end{array}$ & $\begin{array}{l}129.50 \\
125.00\end{array}$ & $\begin{array}{l}58.50 \\
59.00\end{array}$ & $\begin{array}{l}4610 \\
4775\end{array}$ & $\begin{array}{l}47.00 \\
44.75\end{array}$ & $\begin{array}{l}29.35 \\
27.45\end{array}$ & $\begin{array}{l}28.32 \\
27.97\end{array}$ & $\begin{array}{l}25.09 \\
29.27\end{array}$ & $\begin{array}{l}5.85 \\
5.76\end{array}$ \\
\hline 2 & $\begin{array}{l}\text { LB } \\
\text { B1 }\end{array}$ & $\begin{array}{l}125.00 \\
125.00\end{array}$ & $\begin{array}{l}58.50 \\
58.50\end{array}$ & $\begin{array}{l}4260 \\
4075\end{array}$ & $\begin{array}{l}46.25 \\
46.25\end{array}$ & $\begin{array}{l}34.80 \\
34.70\end{array}$ & $\begin{array}{l}26.23 \\
27.08\end{array}$ & $\begin{array}{l}25.35 \\
26.81\end{array}$ & $\begin{array}{l}5.43 \\
5.49\end{array}$ \\
\hline 3 & $\begin{array}{l}\mathrm{R} \\
\mathrm{B} 1\end{array}$ & $\begin{array}{l}117.50 \\
121.50\end{array}$ & $\begin{array}{l}59.00 \\
59.00\end{array}$ & $\begin{array}{l}4460 \\
4105\end{array}$ & $\begin{array}{l}48.25 \\
45.75\end{array}$ & $\begin{array}{l}34.65 \\
31.25\end{array}$ & $\begin{array}{l}25.67 \\
29.16\end{array}$ & $\begin{array}{l}26.46 \\
29.31\end{array}$ & $\begin{array}{l}5.22 \\
5.42\end{array}$ \\
\hline 4 & $\begin{array}{l}\mathrm{R} \\
\mathrm{B} 1\end{array}$ & -- & - & - & - & - & - & $\begin{array}{l}24.46 \\
28.00\end{array}$ & $\begin{array}{l}5.38 \\
6.18\end{array}$ \\
\hline 5 & $\begin{array}{l}\text { LB } \\
\text { B1 }\end{array}$ & $\begin{array}{l}123.00 \\
118.50\end{array}$ & $\begin{array}{l}59.50 \\
59.50\end{array}$ & $\begin{array}{l}4790 \\
4695\end{array}$ & $\begin{array}{l}50.50 \\
46.25\end{array}$ & $\begin{array}{l}30.20 \\
30.05\end{array}$ & $\begin{array}{l}24.88 \\
26.07\end{array}$ & $\begin{array}{l}23.99 \\
26.14\end{array}$ & $\begin{array}{l}5.43 \\
5.91\end{array}$ \\
\hline 6 & $\begin{array}{l}\mathrm{W} \\
\mathrm{B} 1\end{array}$ & -- & - & - & - & - & - & - & $\begin{array}{l}5.35 \\
5.87\end{array}$ \\
\hline 7 & $\begin{array}{l}\mathrm{Y} \\
\mathrm{B} 1\end{array}$ & $\begin{array}{l}126.00 \\
121.00\end{array}$ & $\begin{array}{l}61.00 \\
63.00\end{array}$ & $\begin{array}{l}4455 \\
4150\end{array}$ & $\begin{array}{l}44.75 \\
42.00\end{array}$ & $\begin{array}{l}32.45 \\
33.50\end{array}$ & $\begin{array}{l}27.54 \\
27.30\end{array}$ & $\begin{array}{l}26.12 \\
25.57\end{array}$ & -- \\
\hline 8 & $\begin{array}{l}\mathrm{LB} \\
\mathrm{B} 1\end{array}$ & $\begin{array}{l}135.50 \\
126.50\end{array}$ & $\begin{array}{l}58.50 \\
59.00\end{array}$ & $\begin{array}{l}4805 \\
4710\end{array}$ & $\begin{array}{l}47.00 \\
44.75\end{array}$ & $\begin{array}{l}31.50 \\
32.30\end{array}$ & $\begin{array}{l}26.24 \\
28.28\end{array}$ & $\begin{array}{l}26.61 \\
28.26\end{array}$ & $\begin{array}{l}5.37 \\
5.82\end{array}$ \\
\hline 9 & $\begin{array}{l}\mathrm{W} \\
\mathrm{B} 1\end{array}$ & $\begin{array}{l}126.50 \\
129.00\end{array}$ & $\begin{array}{l}60.00 \\
60.00\end{array}$ & $\begin{array}{l}4915 \\
4275\end{array}$ & $\begin{array}{l}46.00 \\
44.00\end{array}$ & $\begin{array}{l}38.25 \\
34.50\end{array}$ & $\begin{array}{l}27.87 \\
28.77\end{array}$ & $\begin{array}{l}26.03 \\
29.32\end{array}$ & $\begin{array}{l}5.29 \\
5.52\end{array}$ \\
\hline 10 & $\begin{array}{l}\text { LB } \\
\text { B1 }\end{array}$ & - & - & - & - & -- & -- & $\begin{array}{l}24.58 \\
25.21\end{array}$ & $\begin{array}{l}5.49 \\
5.63\end{array}$ \\
\hline
\end{tabular}

If light-brown (LB), black (B1), red (R), yellow (Y) and white (W) lemma colour 
APPENDIX 5. Number of days to reach maximum germination, percent germination and germination index of the white versus red near-isogenic pairs of lines grown in greenhouse in 1984

\begin{tabular}{|c|c|c|c|c|}
\hline Pair & $\begin{array}{l}\text { Lemma } \\
\text { Colour }\end{array}$ & $\begin{array}{l}\text { No of days } \\
\text { max. germination }\end{array}$ & $\begin{array}{l}\text { Percent } \\
\text { germination }\end{array}$ & $\begin{array}{l}\text { Germination } \\
\text { index }\end{array}$ \\
\hline 8 & $\begin{array}{l}W T \\
\mathrm{R}\end{array}$ & $\begin{array}{l}6.00 \\
7.00\end{array}$ & $\begin{array}{l}97.50 \\
87.50\end{array}$ & $\begin{array}{l}63.00 \\
54.00\end{array}$ \\
\hline 12 & $\begin{array}{l}W \\
R\end{array}$ & $\begin{array}{l}5.00 \\
5.50\end{array}$ & $\begin{array}{l}100.00 \\
100.00\end{array}$ & $\begin{array}{l}72.00 \\
66.50\end{array}$ \\
\hline 13 & $\begin{array}{l}W \\
R\end{array}$ & $\begin{array}{l}6.00 \\
6.00\end{array}$ & $\begin{array}{l}100.00 \\
100.00\end{array}$ & $\begin{array}{l}67.00 \\
63.50\end{array}$ \\
\hline 17 & $\begin{array}{l}\mathrm{W} \\
\mathrm{R}\end{array}$ & $\begin{array}{l}5.00 \\
6.00\end{array}$ & $\begin{array}{l}100.00 \\
100.00\end{array}$ & $\begin{array}{l}66.50 \\
62.50\end{array}$ \\
\hline 20 & $\begin{array}{l}\mathrm{W} \\
\mathrm{R}\end{array}$ & $\begin{array}{l}5.00 \\
5.50\end{array}$ & $\begin{array}{l}100.00 \\
100.00\end{array}$ & $\begin{array}{l}64.50 \\
63.00\end{array}$ \\
\hline 22 & $\begin{array}{l}\mathrm{W} \\
\mathrm{R}\end{array}$ & $\begin{array}{l}5.00 \\
5.00\end{array}$ & $\begin{array}{l}100.00 \\
100.00\end{array}$ & $\begin{array}{l}64.00 \\
67.00\end{array}$ \\
\hline 24 & $\begin{array}{l}\mathrm{W} \\
\mathrm{R}\end{array}$ & $\begin{array}{l}6.00 \\
7.00\end{array}$ & $\begin{array}{l}100.00 \\
100.00\end{array}$ & $\begin{array}{l}65.50 \\
51.25\end{array}$ \\
\hline 34 & $\begin{array}{l}W \\
R\end{array}$ & $\begin{array}{l}5.50 \\
6.00\end{array}$ & $\begin{array}{l}100.00 \\
100.00\end{array}$ & $\begin{array}{l}60.50 \\
63.00\end{array}$ \\
\hline Line ? & $\begin{array}{ll}288^{\S} & W \\
293 & R\end{array}$ & $\begin{array}{l}5.50 \\
6.00\end{array}$ & $\begin{array}{l}100.00 \\
100.00\end{array}$ & $\begin{array}{l}61.50 \\
56.50\end{array}$ \\
\hline & $\begin{array}{ll}477 & W \\
481 & R\end{array}$ & $\begin{array}{l}6.50 \\
5.50\end{array}$ & $\begin{array}{l}100.00 \\
100.00\end{array}$ & $\begin{array}{l}51.00 \\
63.00\end{array}$ \\
\hline
\end{tabular}

T white (W) and red (R)lemma colour

$\S$ pairs of lines excluded from the 1984 trial because of short seed supply 
APPENDIX 6. Number of days to reach maximum germination, percent germination and germination index of the yellow versus red near-isogenic pairs of lines grown in greenhouse in 1984

\begin{tabular}{|c|c|c|c|c|}
\hline Pair & $\begin{array}{l}\text { Lemma } \\
\text { Colour }\end{array}$ & $\begin{array}{c}\text { No of days } \\
\text { max. germination }\end{array}$ & $\begin{array}{l}\text { Percent } \\
\text { germination }\end{array}$ & $\begin{array}{l}\text { Germination } \\
\text { index }\end{array}$ \\
\hline 1 & $\begin{array}{l}\mathrm{Y} T \\
\mathrm{R}\end{array}$ & $\begin{array}{l}6.00 \\
6.50\end{array}$ & $\begin{array}{l}100.00 \\
100.00\end{array}$ & $\begin{array}{l}60.00 \\
55.00\end{array}$ \\
\hline 4 & $\begin{array}{l}\mathrm{Y} \\
\mathrm{R}\end{array}$ & $\begin{array}{l}5.50 \\
6.00\end{array}$ & $\begin{array}{l}100.00 \\
100.00\end{array}$ & $\begin{array}{l}63.00 \\
58.50\end{array}$ \\
\hline 5 & $\begin{array}{l}\mathrm{Y} \\
\mathrm{R}\end{array}$ & $\begin{array}{l}6.00 \\
6.50\end{array}$ & $\begin{array}{l}100.00 \\
100.00\end{array}$ & $\begin{array}{l}56.00 \\
57.75\end{array}$ \\
\hline 10 & $\begin{array}{l}\mathrm{Y} \\
\mathrm{R}\end{array}$ & $\begin{array}{l}6.00 \\
6.00\end{array}$ & $\begin{array}{l}100.00 \\
100.00\end{array}$ & $\begin{array}{l}62.50 \\
56.50\end{array}$ \\
\hline 11 & $\begin{array}{l}\mathrm{Y} \\
\mathrm{R}\end{array}$ & $\begin{array}{l}5.50 \\
7.00\end{array}$ & $\begin{array}{l}100.00 \\
90.00\end{array}$ & $\begin{array}{l}64.50 \\
46.00\end{array}$ \\
\hline 12 & $\begin{array}{l}\mathrm{Y} \\
\mathrm{R}\end{array}$ & $\begin{array}{l}5.00 \\
6.00\end{array}$ & $\begin{array}{l}100.00 \\
100.00\end{array}$ & $\begin{array}{l}63.00 \\
50.00\end{array}$ \\
\hline 13 & $\begin{array}{l}\mathrm{Y} \\
\mathrm{R}\end{array}$ & $\begin{array}{l}7.00 \\
5.50\end{array}$ & $\begin{array}{l}100.00 \\
100.00\end{array}$ & $\begin{array}{l}55.50 \\
62.00\end{array}$ \\
\hline 17 & $\begin{array}{l}\mathrm{Y} \\
\mathrm{R}\end{array}$ & $\begin{array}{l}6.00 \\
6.00\end{array}$ & $\begin{array}{l}100.00 \\
100.00\end{array}$ & $\begin{array}{l}62.50 \\
56.50\end{array}$ \\
\hline 18 & $\begin{array}{l}\mathrm{Y} \\
\mathrm{R}\end{array}$ & $\begin{array}{l}5.50 \\
5.50\end{array}$ & $\begin{array}{l}100.00 \\
100.00\end{array}$ & $\begin{array}{l}62.00 \\
60.00\end{array}$ \\
\hline 19 & $\begin{array}{l}\mathrm{Y} \\
\mathrm{R}\end{array}$ & $\begin{array}{l}5.00 \\
6.50\end{array}$ & $\begin{array}{l}100.00 \\
100.00\end{array}$ & $\begin{array}{l}64.50 \\
56.50\end{array}$ \\
\hline
\end{tabular}

T yellow (Y) and red (R) lemma colour 
APPENDIX 7. Number of days to reach maximum germination, percent germination and germination index of the yellow versus white near-isogenic pairs of lines grown in greenhouse in 1984

\begin{tabular}{|c|c|c|c|c|}
\hline Pair & $\begin{array}{l}\text { Lemma } \\
\text { Colour }\end{array}$ & $\begin{array}{c}\text { No of days } \\
\text { max. germination }\end{array}$ & $\begin{array}{l}\text { Percent } \\
\text { germination }\end{array}$ & $\begin{array}{l}\text { Germination } \\
\text { index }\end{array}$ \\
\hline 1 & $\begin{array}{l}\mathrm{Y} \text { W } \\
\mathrm{W}\end{array}$ & $\begin{array}{l}6.00 \\
5.50\end{array}$ & $\begin{array}{l}100.00 \\
100.00\end{array}$ & $\begin{array}{l}58.50 \\
61.00\end{array}$ \\
\hline 2 & $\begin{array}{l}Y \\
W\end{array}$ & $\begin{array}{l}6.00 \\
6.00\end{array}$ & $\begin{array}{l}100.00 \\
100.00\end{array}$ & $\begin{array}{l}59.50 \\
59.50\end{array}$ \\
\hline 3 & $\begin{array}{l}Y \\
W\end{array}$ & $\begin{array}{l}5.50 \\
5.50\end{array}$ & $\begin{array}{l}100.00 \\
100.00\end{array}$ & $\begin{array}{l}61.00 \\
60.00\end{array}$ \\
\hline 4 & $\begin{array}{l}\mathrm{Y} \\
\mathrm{W}\end{array}$ & $\begin{array}{l}6.50 \\
5.00\end{array}$ & $\begin{array}{l}100.00 \\
100.00\end{array}$ & $\begin{array}{l}62.50 \\
65.50\end{array}$ \\
\hline 5 & $\begin{array}{l}Y \\
W\end{array}$ & $\begin{array}{l}5.50 \\
5.50\end{array}$ & $\begin{array}{c}100.00 \\
97.50\end{array}$ & $\begin{array}{l}65.50 \\
64.50\end{array}$ \\
\hline 6 & $\begin{array}{l}\mathrm{Y} \\
\mathrm{W}\end{array}$ & $\begin{array}{l}6.50 \\
5.50\end{array}$ & $\begin{array}{l}100.00 \\
100.00\end{array}$ & $\begin{array}{l}63.00 \\
61.50\end{array}$ \\
\hline 7 & $\begin{array}{l}Y \\
W\end{array}$ & $\begin{array}{l}6.00 \\
5.50\end{array}$ & $\begin{array}{l}100.00 \\
100.00\end{array}$ & $\begin{array}{l}65.50 \\
68.00\end{array}$ \\
\hline 8 & $\begin{array}{l}\mathrm{Y} \\
\mathrm{W}\end{array}$ & $\begin{array}{l}5.50 \\
5.50\end{array}$ & $\begin{array}{l}100.00 \\
100.00\end{array}$ & $\begin{array}{l}63.50 \\
67.00\end{array}$ \\
\hline 10 & $\begin{array}{l}Y \\
W\end{array}$ & $\begin{array}{l}6.00 \\
6.00\end{array}$ & $\begin{array}{l}100.00 \\
100.00\end{array}$ & $\begin{array}{l}56.20 \\
60.00\end{array}$ \\
\hline
\end{tabular}

I Yellow (Y) and white (W) lemma colour 
APPENDIX 8. Number of days to reach maximum germination, percent germination and germination index of the black versus non-black nearisogenic pairs of lines grown in greenhouse in 1984

\begin{tabular}{|c|c|c|c|c|}
\hline Pair & $\begin{array}{l}\text { Lemma } \\
\text { Colour }\end{array}$ & $\begin{array}{l}\text { No of days } \\
\text { max. germination }\end{array}$ & $\begin{array}{l}\text { Percent } \\
\text { germination }\end{array}$ & $\begin{array}{l}\text { Germination } \\
\text { index }\end{array}$ \\
\hline 1 & $\begin{array}{l}\text { LBT } \\
\text { B1 }\end{array}$ & $\begin{array}{l}6.00 \\
7.00\end{array}$ & $\begin{array}{l}100.00 \\
100.00\end{array}$ & $\begin{array}{l}62.50 \\
56.00\end{array}$ \\
\hline 2 & $\begin{array}{l}\mathrm{LB} \\
\mathrm{B} 1\end{array}$ & $\begin{array}{l}6.50 \\
6.00\end{array}$ & $\begin{array}{l}100.00 \\
100.00\end{array}$ & $\begin{array}{l}55.00 \\
56.00\end{array}$ \\
\hline 3 & $\begin{array}{l}\mathrm{R} \\
\mathrm{BI}\end{array}$ & $\begin{array}{l}6.50 \\
6.00\end{array}$ & $\begin{array}{c}97.50 \\
100.00\end{array}$ & $\begin{array}{l}58.50 \\
56.40\end{array}$ \\
\hline 4 & $\begin{array}{l}\mathrm{R} \\
\mathrm{B} 1\end{array}$ & $\begin{array}{l}6.00 \\
6.00\end{array}$ & $\begin{array}{l}100.00 \\
100.00\end{array}$ & $\begin{array}{l}66.00 \\
64.00\end{array}$ \\
\hline 5 & $\begin{array}{l}\mathrm{LB} \\
\mathrm{B} 1\end{array}$ & $\begin{array}{l}6.50 \\
7.00\end{array}$ & $\begin{array}{l}100.00 \\
97.50\end{array}$ & $\begin{array}{l}54.00 \\
47.00\end{array}$ \\
\hline 7 & $\begin{array}{l}\mathrm{Y} \\
\mathrm{B} 1\end{array}$ & $\begin{array}{l}6.50 \\
5.00\end{array}$ & $\begin{array}{l}100.00 \\
100.00\end{array}$ & $\begin{array}{l}56.50 \\
62.00\end{array}$ \\
\hline 8 & $\begin{array}{l}\text { LB } \\
\text { B1 }\end{array}$ & $\begin{array}{l}5.50 \\
6.00\end{array}$ & $\begin{array}{l}100.00 \\
100.00\end{array}$ & $\begin{array}{l}65.00 \\
61.50\end{array}$ \\
\hline 9 & $\begin{array}{l}\mathrm{W} \\
\mathrm{B} 1\end{array}$ & $\begin{array}{l}6.50 \\
6.50\end{array}$ & $\begin{array}{l}100.00 \\
100.00\end{array}$ & $\begin{array}{l}60.00 \\
61.00\end{array}$ \\
\hline 10 & $\begin{array}{l}\mathrm{LB} \\
\mathrm{B} 1\end{array}$ & $\begin{array}{l}6.00 \\
5.50\end{array}$ & $\begin{array}{l}100.00 \\
100.00\end{array}$ & $\begin{array}{l}63.50 \\
61.00\end{array}$ \\
\hline
\end{tabular}

I light-brown (LB), black (B1), red (R), yellow (Y) and white(W) lemma colour 
APPENDIX 9. Whole grain protein percent and groat protein percent of the white versus red near-isogenic pairs of lines grown at Glenlea, Manitoba in 1983

\begin{tabular}{|c|c|c|c|c|}
\hline \multirow[t]{2}{*}{ Pair } & \multicolumn{2}{|c|}{$\begin{array}{c}\text { Percent protein } \mathbb{1} \\
\text { (grain) }\end{array}$} & \multicolumn{2}{|c|}{$\begin{array}{c}\text { Percent protein } \\
\text { (groat) }\end{array}$} \\
\hline & White & Red & White & Red \\
\hline 2 & 12.79 & 14.07 & 18.62 & 19.08 \\
\hline 5 & 14.43 & 15.30 & 19.06 & 19.27 \\
\hline 7 & 14.10 & 15.08 & 17.73 & 17.88 \\
\hline 8 & 14.71 & 14.63 & 19.34 & 18.37 \\
\hline 9 & 15.26 & 13.56 & 18.05 & 19.05 \\
\hline 10 & 13.07 & 13.80 & 18.47 & 18.59 \\
\hline 11 & 13.42 & 12.62 & 21.45 & 20.94 \\
\hline 12 & 13.52 & 14.35 & 18.98 & 21.41 \\
\hline 13 & 13.48 & 13.37 & 19.99 & 22.67 \\
\hline 14 & 14.33 & 14.51 & 20.18 & 20.87 \\
\hline 18 & 14.67 & 13.92 & 19.77 & 20.88 \\
\hline 19 & 13.50 & 13.95 & 20.13 & 19.68 \\
\hline 21 & 14.06 & 14.23 & 20.52 & 20.79 \\
\hline 23 & 12.99 & 13.37 & 24.75 & 21.51 \\
\hline 27 & 13.29 & 13.77 & 17.75 & 18.17 \\
\hline 29 & 15.42 & 14.65 & 18.83 & 16.91 \\
\hline 32 & 13.34 & 14.64 & 18.85 & 20.02 \\
\hline 34 & 13.35 & 13.43 & 17.62 & 17.70 \\
\hline 35 & 14.49 & 16.64 & 17.79 & 17.62 \\
\hline 38 & 15.10 & 15.00 & 19.22 & 19.16 \\
\hline 39 & 16.76 & 15.12 & 20.25 & 18.22 \\
\hline Line $288 \S$ & 13.57 & line 29313.36 & 20.80 & 18.83 \\
\hline
\end{tabular}

II Nitrogen X 6.25

$\S$ pair of lines excluded from the 1984 trial because of short seed supply 
APPENDIX 10. Whole grain protein percent and groat protein percent of the yellow versus red near-isogenic pairs of lines grown at Glenlea, Manitoba in 1983

\begin{tabular}{|c|c|c|c|}
\hline Pair & $\begin{array}{l}\text { Lemma } \\
\text { Colour }\end{array}$ & $\begin{array}{c}\text { Percent protein } \\
\text { (grain) }\end{array}$ & $\begin{array}{l}\text { Percent protein } \\
\text { (groat) }\end{array}$ \\
\hline 7 & $\begin{array}{l}\mathrm{Y} S \\
\mathrm{R}\end{array}$ & $\begin{array}{l}11.80 \\
12.93\end{array}$ & $\begin{array}{l}16.55 \\
18.44\end{array}$ \\
\hline 9 & $\begin{array}{l}\mathrm{Y} \\
\mathrm{R}\end{array}$ & $\begin{array}{l}14.06 \\
13.30\end{array}$ & $\begin{array}{l}20.13 \\
18.89\end{array}$ \\
\hline 10 & $\begin{array}{l}\mathrm{Y} \\
\mathrm{R}\end{array}$ & $\begin{array}{l}15.33 \\
12.81\end{array}$ & $\begin{array}{l}22.00 \\
17.93\end{array}$ \\
\hline 11 & $\begin{array}{l}\mathrm{Y} \\
\mathrm{R}\end{array}$ & $\begin{array}{l}14.04 \\
14.87\end{array}$ & $\begin{array}{l}19.70 \\
21.92\end{array}$ \\
\hline 12 & $\begin{array}{l}\mathrm{Y} \\
\mathrm{R}\end{array}$ & $\begin{array}{l}15.26 \\
14.57\end{array}$ & $\begin{array}{l}21.43 \\
20.46\end{array}$ \\
\hline 14 & $\begin{array}{l}\mathrm{Y} \\
\mathrm{R}\end{array}$ & $\begin{array}{l}15.25 \\
14.36\end{array}$ & $\begin{array}{l}21.82 \\
19.56\end{array}$ \\
\hline 17 & $\begin{array}{l}\mathrm{Y} \\
\mathrm{R}\end{array}$ & $\begin{array}{l}13.67 \\
13.89\end{array}$ & $\begin{array}{l}19.36 \\
19.26\end{array}$ \\
\hline 18 & $\begin{array}{l}\mathrm{Y} \\
\mathrm{R}\end{array}$ & $\begin{array}{l}14.69 \\
14.61\end{array}$ & $\begin{array}{l}21.20 \\
20.32\end{array}$ \\
\hline 19 & $\begin{array}{l}\mathrm{Y} \\
\mathrm{R}\end{array}$ & $\begin{array}{l}14.92 \\
14.82\end{array}$ & $\begin{array}{l}21.49 \\
20.11\end{array}$ \\
\hline $\begin{array}{r}\text { Line } \#^{\ddagger} \\
809 \\
811\end{array}$ & $\begin{array}{l}\mathrm{Y} \\
\mathrm{R}\end{array}$ & $\begin{array}{l}12.48 \\
13.38\end{array}$ & $\begin{array}{l}17.89 \\
18.59\end{array}$ \\
\hline $\begin{array}{l}967 \\
971\end{array}$ & $\begin{array}{l}\mathrm{Y} \\
\mathrm{R}\end{array}$ & $\begin{array}{l}14.46 \\
14.00\end{array}$ & $\begin{array}{l}20.47 \\
20.41\end{array}$ \\
\hline
\end{tabular}

I Nitrogen $X 6.25$

$\S$ yellow $(Y)$ and red $(R)$ lemma colour

$\neq$ pairs of lines excluded from the 1984 trial because of short seed supply 
APPENDIX 11. Whole grain protein percent and groat protein percent of the yellow versus white near-isogenic pairs of lines grown at Glenlea Manitoba in 1983

\begin{tabular}{cccc}
\hline Pair & $\begin{array}{c}\text { Lemma } \\
\text { Colour }\end{array}$ & $\begin{array}{c}\text { Percent protein } \\
\text { (grain) }\end{array}$ & $\begin{array}{c}\text { Percent protein } \\
\text { (groat) }\end{array}$ \\
\hline \multirow{2}{*}{1} & Y§ & 12.21 & 17.34 \\
& W & 13.33 & 20.20 \\
2 & Y & 12.82 & 18.12 \\
& W & 12.34 & 17.38 \\
3 & Y & 12.55 & 17.75 \\
& W & 13.18 & 18.92 \\
4 & Y & 13.60 & 19.07 \\
& W & 12.94 & 17.55 \\
5 & Y & 13.86 & 18.99 \\
& W & 14.26 & 19.56 \\
6 & Y & 13.71 & 19.21 \\
& W & 13.64 & 18.30 \\
7 & Y & 14.09 & 19.74 \\
& W & 13.70 & 18.02 \\
8 & Y & 14.74 & 20.32 \\
& W & 14.58 & 19.02 \\
9 & Y & 14.67 & 20.23 \\
& W & 15.04 & 21.31 \\
10 & Y & 13.01 & 19.77 \\
& W & 12.24 & 16.68 \\
& & &
\end{tabular}

T Nitrogen X 6.25

$\S$ yellow (Y) and white (W) lemma colour 
APPENDIX 12. Whole grain protein percent and groat protein percent of the black versus non-black near-isogenic pairs of lines grown at Glenlea, Manitoba in 1983

\begin{tabular}{|c|c|c|c|}
\hline Pair & $\begin{array}{l}\text { Lemma } \\
\text { Colour }\end{array}$ & $\begin{array}{l}\text { Percent protein } \\
\text { (grain) }\end{array}$ & $\begin{array}{c}\text { Percent protein } \\
\text { (groat) }\end{array}$ \\
\hline 1 & $\begin{array}{l}\text { LBS } \\
\text { B1 }\end{array}$ & $\begin{array}{l}15.50 \\
15.43\end{array}$ & $\begin{array}{l}20.70 \\
21.82\end{array}$ \\
\hline 2 & $\begin{array}{l}\text { LB } \\
\text { B1 }\end{array}$ & $\begin{array}{l}14.26 \\
15.40\end{array}$ & $\begin{array}{l}19.11 \\
21.04\end{array}$ \\
\hline 3 & $\begin{array}{l}\mathrm{R} \\
\mathrm{B} 1\end{array}$ & $\begin{array}{l}15.70 \\
16.65\end{array}$ & $\begin{array}{l}21.35 \\
23.55\end{array}$ \\
\hline 4 & $\begin{array}{l}\mathrm{R} \\
\mathrm{B} 1\end{array}$ & $\begin{array}{l}14.84 \\
13.49\end{array}$ & $\begin{array}{l}19.64 \\
18.74\end{array}$ \\
\hline 5 & $\begin{array}{l}\text { LB } \\
\text { B1 }\end{array}$ & $\begin{array}{l}14.92 \\
16.45\end{array}$ & $\begin{array}{l}19.63 \\
22.27\end{array}$ \\
\hline 6 & $\begin{array}{l}\text { W } \\
\text { B1 }\end{array}$ & $\begin{array}{l}16.09 \\
16.28\end{array}$ & - \\
\hline 7 & $\begin{array}{l}\mathrm{Y} \\
\mathrm{BI}\end{array}$ & $\begin{array}{l}17.74 \\
16.84\end{array}$ & $\begin{array}{l}23.98 \\
22.63\end{array}$ \\
\hline 8 & $\begin{array}{l}\mathrm{LB} \\
\mathrm{B} 1\end{array}$ & $\begin{array}{l}15.67 \\
14.50\end{array}$ & $\begin{array}{l}21.35 \\
20.21\end{array}$ \\
\hline 9 & $\begin{array}{l}\mathrm{W} \\
\mathrm{B} 1\end{array}$ & $\begin{array}{l}15.00 \\
15.44\end{array}$ & $\begin{array}{l}20.28 \\
21.84\end{array}$ \\
\hline 10 & $\begin{array}{l}\text { LB } \\
\text { B1 }\end{array}$ & $\begin{array}{l}15.03 \\
15.15\end{array}$ & $\begin{array}{l}19.93 \\
20.26\end{array}$ \\
\hline
\end{tabular}

I Nitrogen X 6.25

$\S$ light-brown (LB), black (BI), red (R), yellow (Y) and white (W) 
APPENDIX 13. Analyses of variance of percent hull and percent oil of the near-isogenic lines differing in lemma colour and grown at Glenlea, Manitoba in 1983

\begin{tabular}{lrrrrr}
\hline Source of variation & \multicolumn{2}{c}{$\%$ Hul7 } & & \multicolumn{2}{c}{ \% $0 i 1$} \\
\hline White versus Red & & & & & \\
\hline Pair & 35 & $33.6405^{*}$ & 34 & $1.6870^{* *}$ \\
Colour & 1 & $77.5971^{*}$ & 1 & 0.0131 ns \\
Pair X Colour & 35 & $15.6060^{* *}$ & 34 & $0.2133^{* *}$ \\
Error & 360 & 0.9823 & 140 & 0.0025
\end{tabular}

Yellow versus Red

$\begin{array}{lrcrl}\text { Pair } & 13 & 11.8042 \mathrm{~ns} & 13 & 0.2988 \mathrm{~ns} \\ \text { Colour } & 1 & 4.9303 \mathrm{~ns} & 1 & 0.0899 \mathrm{~ns} \\ \text { Pair X Colour } & 13 & 28.9380^{\star \star} & 13 & 0.1235^{\star \star} \\ \text { Error } & 140 & 1.1873 & 56 & 0.0016\end{array}$

Yellow versus white

$\begin{array}{lrlrl}\text { Pair } & 9 & 47.8265 \mathrm{~ns} & 7 & 0.1849 \mathrm{~ns} \\ \text { Colour } & 1 & 64.7682 \mathrm{~ns} & 1 & 0.2360 \mathrm{~ns} \\ \text { Pair X Colour } & 9 & 38.1336 * * & 7 & 0.3340^{\star *} \\ \text { Error } & 100 & 0.9930 & 32 & 0.0028\end{array}$

Black versus Non-black

$\begin{array}{lrcrl}\text { Pair } & 9 & 14.3852 \text { ns } & 8 & 0.1581 \mathrm{~ns} \\ \text { Colour } & 1 & 134.0910 * * & 1 & 1.3142 * * \\ \text { Pair X Colour } & 9 & 5.8899 * * & 8 & 0.1126 * * \\ \text { Error } & 100 & 0.9231 & 36 & 0.0039\end{array}$

$\mathrm{ns}, *$, ** nonsignificant, significant at 0.05 and 0.01 level of probability respectively 
APPENDIX 14. Analyses of variance of the agronomic characters and grain quality characteristics of the near-isogenic lines differing in lemma colour and grown at Glenlea, Manitoba in 1984

\begin{tabular}{|c|c|c|c|c|c|c|c|}
\hline \multirow[b]{2}{*}{ Source of variation } & \multirow{2}{*}{ d.f. } & \multicolumn{3}{|c|}{ Agronomic Characters } & \multicolumn{3}{|c|}{ Grain Quality Characteristics } \\
\hline & & Height & $\begin{array}{c}\begin{array}{c}\text { Heading } \\
\text { date }\end{array} \\
\text { MS }\end{array}$ & Yield & $\begin{array}{l}\text { Test weight } \\
\frac{\text { MS }}{}\end{array}$ & $\begin{array}{c}1000 \text { kernel } \\
\text { weight }\end{array}$ & $\begin{array}{l}\text { Percent } \\
\text { Hul1 } \\
\end{array}$ \\
\hline \multicolumn{8}{|l|}{ White versus Red } \\
\hline $\begin{array}{l}\text { Pair } \\
\text { Rep (Pair) (error a) } \\
\text { Colour } \\
\text { Pair X Colour } \\
\text { Error (b) }\end{array}$ & $\begin{array}{r}35 \\
62 \\
1 \\
35 \\
62\end{array}$ & $\begin{array}{l}75.2595 * \\
44.0833 * * \\
8.5765 \mathrm{~ns} \\
7.2883 * \\
3.8038\end{array}$ & $\begin{array}{l}27.6759 * * \\
1.9838 * * \\
0.005 \operatorname{lns} \\
0.2713 * * \\
0.1290\end{array}$ & $\begin{array}{l}48.7038 * \\
28.3485 * * \\
1.3390 \mathrm{~ns} \\
7.4402 * * \\
3.0120\end{array}$ & $\begin{array}{l}13.3786 * * \\
3.3710 * * \\
25.0000 * * \\
1.1452 * * \\
0.2325\end{array}$ & $\begin{array}{l}43.4570 * * \\
3.9815 * * \\
3.8865 \mathrm{~ns} \\
3.7863 * * \\
1.8386\end{array}$ & $\begin{array}{l}5.1339 * * \\
0.4456 * \\
68.9018 * * \\
0.5723 * * \\
0.1690\end{array}$ \\
\hline \multicolumn{8}{|l|}{ Yellow versus Red } \\
\hline $\begin{array}{l}\text { Pair } \\
\text { Rep(Pair) (error a) } \\
\text { Colour } \\
\text { Pair X Colour } \\
\text { Error (b) }\end{array}$ & $\begin{array}{r}14 \\
26 \\
1 \\
14 \\
26\end{array}$ & $\begin{array}{l}46.6954 * \\
19.2756 * * \\
8.2439 \mathrm{~ns} \\
8.1850 \mathrm{~ns} \\
3.9295\end{array}$ & $\begin{array}{l}10.5435 * * \\
1.9615 * * \\
2.0610 \mathrm{~ns} \\
0.5314 \mathrm{~ns} \\
0.3846\end{array}$ & $\begin{array}{c}9.7890 \mathrm{~ns} \\
14.1133^{*} \\
7.6219 \mathrm{~ns} \\
7.9226 \mathrm{~ns} \\
5.5120\end{array}$ & $\begin{array}{r}5.1312 \mathrm{~ns} \\
3.2284 * * \\
12.8811 * * \\
1.3611 * * \\
0.4591\end{array}$ & $\begin{array}{l}7.2308 * * \\
2.2284 * * \\
2.7806 \mathrm{~ns} \\
1.2469 \mathrm{~ns} \\
0.6684\end{array}$ & $\begin{array}{l}2.5022 * * \\
0.7059 * \\
25.1361 * * \\
0.7939 * * \\
0.2820\end{array}$ \\
\hline \multicolumn{8}{|l|}{ Yellow versus white } \\
\hline $\begin{array}{l}\text { Pair } \\
\text { Rep (Pair) (error a) } \\
\text { Colour } \\
\text { Pair X Colour } \\
\text { Error (b) }\end{array}$ & $\begin{array}{r}9 \\
19 \\
1 \\
9 \\
19\end{array}$ & $\begin{array}{l}56.5760 * \\
17.4912 * * \\
30.4138 * \\
4.8429 \mathrm{~ns} \\
4.1579\end{array}$ & $\begin{array}{l}24.5670 * * \\
1.1579 * * \\
2.0862 \mathrm{~ns} \\
0.4163 \mathrm{~ns} \\
0.2456\end{array}$ & $\begin{array}{l}8.0185 \mathrm{~ns} \\
9.5101 * \\
4.9243 \mathrm{~ns} \\
7.9472 \mathrm{~ns} \\
4.3287\end{array}$ & $\begin{array}{c}109.3267 * * \\
2.8366 * x \\
4.1422 * \\
0.7782 * x \\
0.1173\end{array}$ & $\begin{array}{c}18.3867 * * \\
4.6060 * \\
26.7648 * \\
3.4520 \mathrm{~ns} \\
2.0167\end{array}$ & $\begin{array}{l}7.4875 * * \\
0.1844 \mathrm{~ns} \\
41.3628 * * \\
0.5073 \mathrm{~ns} \\
0.2144\end{array}$ \\
\hline
\end{tabular}


APPENDIX 14 (cont.)

\begin{tabular}{|c|c|c|c|c|c|c|c|}
\hline \multirow[b]{3}{*}{ Source of variation } & \multirow[b]{3}{*}{ d.f. } & \multicolumn{3}{|c|}{ Agronomic Characters } & \multicolumn{3}{|c|}{ Grain Quality Characteristics } \\
\hline & & Height & $\begin{array}{c}\text { Heading } \\
\text { date }\end{array}$ & Yield & Test weight & $\begin{array}{c}1000 \text { kerne1 } \\
\text { weight }\end{array}$ & $\begin{array}{c}\text { Percent } \\
\text { hull }\end{array}$ \\
\hline & & MS & MS & MS & MS & MS & MS \\
\hline \multicolumn{8}{|l|}{ Black versus Non-black } \\
\hline Replication & 1 & $0.1428 \mathrm{~ns}$ & $11.5714 * *$ & $65.4228 * x$ & $1.2857 \mathrm{~ns}$ & $6.7032 * *$ & $0.2126 \mathrm{~ns}$ \\
\hline Pair & 6 & $66.1667 *$ & $5.9167 * *$ & $24.5223 *$ & $9.7440 * *$ & $28.8778 *$ & $3.6660 * *$ \\
\hline Rep X Pair (error a) & 6 & $9.9762 \mathrm{~ns}$ & $0.4881 *$ & $4.0637 \mathrm{~ns}$ & $0.6190 \mathrm{~ns}$ & $5.4570 *$ & $0.3452 \mathrm{~ns}$ \\
\hline Colour & 1 & $36.5714 \mathrm{~ns}$ & $1.2857 \mathrm{~ns}$ & $32.5728 \mathrm{~ns}$ & $36.5714 * *$ & $7.9289 \mathrm{~ns}$ & $8.8706 \mathrm{~ns}$ \\
\hline Pair X Colour & 6 & $22.0714 \mathrm{~ns}$ & $0.5357 * *$ & $6.3737 \mathrm{~ns}$ & $1.5714 \mathrm{~ns}$ & $3.8464 \mathrm{~ns}$ & $1.7688 *$ \\
\hline Error (b) & 7 & 16.0000 & 0.0714 & 4.0536 & 1.1428 & 1.4068 & 0.3695 \\
\hline
\end{tabular}

$\mathrm{ns}, *, * *$ nonsignificant and significant at 0.05 and 0.01 level of probability respectively 